\title{
SYNTHESES OF OLIGOMERS OF THE CAPSULAR POLYSACCHARIDE \\ OF HAEMOPHILUS INFLUENZAE TYPE b \\ BACTERIA
}

\section{BY \\ LaVal Chan ChUN Kong}

A thesis submitted to the Faculty of Graduate Studies

and Research of McGill University in partial

fulfilment of the requirements for the

Degree of Doctor of Philosophy

Department of Chemistry

McGill University

February 1989

Montreal, Quebec

Canada 
Syntheses of oligosaccharides of Haemophilus influenza type $b$ bacteria 
0

To my parents

To Joyce

0 


\section{ABSTRACT}

A new approach to the ribofuranosyl-ribitol unit of the capsular polysaccharide of Haemophilus influenzae type b (Hib) was developed. Reaction of 5-0-ally1-2,3,4-tri-Obenzyl D-ribitol with chloro 2-O-acetyl-3-O-allyl-5-O-benzyl- $\beta$-D-ribofuranoside under yield. Further protecting group manipulations and suitable functionalisation allowed the construction of a dimeric fragment by the use of phosphoramidite chemistry. Oligomers $(n=$ 1-5) of the polysaccharide carrying a D-ribose spacer on the 3' position were then synthesized. These compounds have potential use as a synthetic vaccine component for immunization against Hib meningitis. Preliminary tests have shown that the tetramer gave promising results.

An attempt to synthesize fragments of Escherichia coli $\mathrm{K} 100$ bacteria polysaccharide which is cross-reactive with the Hib polysaccharide was made.

In connection with the synthesis of Goniothalenol, a new protecting group, the $p, p^{\prime}$-dinitrobenzhydryl ether was developed. The formation and removal of this protecting group was described 


\section{RESUME}

La synthèse de l'unité ribosyl-ribitol du polysaccharide capsulaire de la bactérie Haemophilus influenzae type b (Hib) par une nouvelle approche a tte accomplie. La rtaction de 5-O-allyl 2,3,4-tri-O-benzyl-D-ribitol avec le chloro 2-0-acetyl-3-0-allyl-5-0-benzylB-D-ribofuranose moyennant la méthode de Koenigs-Knorr a donné un bon rendement du produit désirt. Des oligomères $(n=1-5)$ du polysaccharide portant une unite ribose comme lien ont ensuite été synthètisés. Ces produits sont des composantes potentielles pour la préparation d'un vaccin artificiel contre la méningite causée par la bactérie Hib. On a trouvé que le tetramère était immunogenique.

La synthèse de fragments du polysaccharide capsulaire de Escherichia coli K100 a ett tentée. Ce polysaccharide est aussi censé d'immuniser contre la meningite causte par la bacterie Hib.

Un nouveau groupement protecteur, l'éther $p, p^{\prime}$-dinitrobenzhydryl, a ette développe. Ce groupement est potentiellement utile pour la synthèse de Goniothalenol. La formation et la déprotection de ce groupement a été décrite. 


\section{ACKNOWLEDGEMENTS}

I would like to express my sincere gratitude to my research director, Professor George Just, for his guidance and encouragement throughout my stay in his laboratory

I also wish to thank:

The Chemistry Department, McGill University for teaching assistantships (1985-1987);

The Natural Science and Engineering Research Council Canada for a scholarship (1987-1989);

Professor Orval A. Mamer for recording mass spectra;

Dr. Françoise Sauriol for assistance in using the XI-200 and XI-300 NMR spectrometers;

Dr. Shadreck Mzengeza for proofreading this manuscript;

All my coworkers, especially Dr. Zhi Yuan Wang and Ms Rina Singh, for their helpful discussions and frienships;

My parents and Joyce for their patience and support. 


\section{GLOSSARY OF ABBREVIATIONS}

\begin{tabular}{|c|c|}
\hline Ac & acetyl \\
\hline $\mathbf{B n}$ & benzyl \\
\hline BOM & benzyloxymethyl \\
\hline br & broad \\
\hline CI & Chemical Ionisation \\
\hline d & doublet \\
\hline dd & doublet of doublets \\
\hline DCC & dicyclohexylcarbodiimide \\
\hline DNB & $p, p^{\prime}$-dinitrobenzhydryl \\
\hline DMAP & $N, N$-dimethylaminopyridine \\
\hline DMF & dimethylformamirie \\
\hline eq & equivalent \\
\hline FAB & Fast Atom Bombardment \\
\hline h & hours \\
\hline Hib & Haemophilus influenzae type b \\
\hline HPLC & High Performance Liqiud Chromatography \\
\hline $\mathbf{m}$ & multiplet \\
\hline $\min$ & minutes \\
\hline MMT & monomethoxytrityl \\
\hline PRP & poly-ribofuranosyl-ribitol-phosphate \\
\hline $\mathbf{q}$ & quartet \\
\hline $\mathbf{r t}$ & room temperature \\
\hline $\mathbf{t}$ & triplet \\
\hline TBDMS & tert-butyldimethylsilyl \\
\hline TCA & trichloroacetic acid \\
\hline THF & tetrahydrofuran \\
\hline TMSCl & trimethylsilyl chloride \\
\hline
\end{tabular}




\section{TABLE OF CONTENTS}

$\begin{array}{lr}\text { ABSTRACT } & \mathbf{i} \\ \text { RÉSUME } & \mathbf{i i} \\ \text { ACKNOWLEDGEMENTS } & \mathbf{i i} \\ \text { GLOSSARY OF ABBREVIATIONS } & \mathbf{i v} \\ \text { TABLE OF CONTENTS } & \mathbf{v} \\ \text { PREFACE } & \text { vii }\end{array}$

CHAPTER 1 INTRODUCTION

1.1 General Overview 1

1.2 Immunisation with PRP alone $\quad 4$

1.3 Simplified overview of the immune system 5

1.4 Conjugate vaccines (non-covalent)

1.5 Conjugate vaccines (covalent) $\quad 8$

1.6 Bigeneric spacer conjugate vaccines 13

$\begin{array}{ll}1.7 \text { Conclusions } & 15\end{array}$

CHAPTER 2

$2.1 \mathrm{Aim}$ and rationale of project $\quad 18$

2.2 Synthesis of the orthoacetate 23

2.3 Synthesis of the ribitol $\quad 25$

2.4 Glycosidation $\quad 26$

2.5 Methods for forming phosphate linkages $\quad 28$

2.6 Synthesis of a dimeric fragment of PRP $\quad 30$

2.7 Deprotection and characterisation of the dimer 33

2.8 Design of the spacer 33

2.9 Synthesis of the spacer 35

2.10 Strategies towards building oligomers of 37

PRP attached to the spacer 
2.11 Synthesis of the monomer-spacer 38

2.12 Deprotection of the monomer-spacer 38

2.13 Synthesis of the silylated spacer $\quad 40$

2.14 Synthesis and deprotection of the monomer-spacer 42

2.15 Synthesis of oligomers of PRP attached to the spacer 45

2.16 Deprotection protocol 46

$\begin{array}{ll}2.17 \text { Biological evaluation of the haptens } & 48\end{array}$

\section{CHAPTER 3}

Attempted synthesis of fragments of the Escherichia coli

K100 capsular polysaccharide

\section{CHAPTER 4}

4.1 Attempts at obtaining the ribosyl-ribitol moiety by

a more efficient approach

4.2 Approaches for glycosidation

\section{APPENDIX}

Towards the synthesis of Goniothalenol

CONTRIBUTIONS TO KNOWLEDGE

\section{EXPERIMENTAL}

General methods

Chapter 2

Chapter 3

Chapter 4 


\section{PREFACE}

We initially started with the synthesis of Goniothalenol, which appears in the appendix. During the course of that study, protecting group incompatibility prompted us to seek the development of a new blocking group which would have had a potential use in our approach. Unfortunately, when the blocking group project was completed, French authors described the synthesis of Goniothalenol by two different approaches; one of which was virtually identical to our proposed scheme. We therefore discontinued the Goniothalenol project and started with what will constitute the first and major part of this thesis. This project deals with the synthesis of haptens of the Haemophilus influenzae type b bacteria. Preliminary and important work on this project has recently (1987) been completed by Wang and submitted as part of a PhD thesis. 


\section{Chapter 1 Introduction}

\subsection{General Overview}

Scientists have been fascinated by the Haemophilus influenzae bacteria since their discovery in 1883 by Koch. In those days the bacteria were known as Haemophilus aegyptius because they were first detected in Egypt. Later (1892) Richard Pfeiffer observed large numbers of the bacteria in the sputa of influenza patients and thus incorrectly blamed the Haemophilus bacteria as the chief culprit for this disease. The myth was so widespread that the bacteria was renamed Haemophilus influenzae. Eventually, the influenza viruses were discovered in 1933 and the Haemophilus influenzae bacteria were exonerated, but the name persists until today!

The work of Margaret Pittman in 1931 laid the foundations for our understanding of the Haemophilus influenzae bacteria. She found that the bacteria existed as two different strains which had very different pathogenic and antigenic properties. This difference was explained by her postulation that the bacteria existed as a capsulated and a non-capsulated species, the capsulated strain being more resistant and therefore more virulent. The capsulated strain could further be separated into six serologically distinguishable types which were designated type a-f. Pittmann also identified type $b$ as the main culprit for causing meningitis and other Haemophilus influenzae infections. Since the pioneering work of Pittman, a considerable body of evidence has been gathered and Table 1 summarizes our present knowledge of the pathogenicity and carriage rates of the Haemophilus influenzae bacteria. The non-capsular strain, as predicted by Pittmann, was non-pathogenic and only appears in the body when the immune system is weakened at the onset of an infection ${ }^{1}$.

In an attempt to provide an explanation for the especially high virulence of the $b$ type, the composition of the capsular material was determined by a combination of 
chemical degradation and NMR techniques. The capsular material of all the six serotypes have now been shown to consist mainly of polysaccharides, and all except type $d$ and $e$ contain phosphodiester linkages ${ }^{2}$. Type e bacteria also exist as two distinct strains and therefore have different capsular materials. Table 2 shows the structures of the different

Table 1 Carriage and pathogenicity of Haemophilus influenzae

\begin{tabular}{lll} 
Strains & $\begin{array}{l}\text { Common } \\
\text { nasopharyngeal } \\
\text { carriage rates }\end{array}$ & $\begin{array}{l}\text { Principal manifestations } \\
\text { of pathogenicity }\end{array}$ \\
\hline $\begin{array}{l}\text { Capsulated, } \\
\text { type b }\end{array}$ & $2-4 \%$ & $\begin{array}{l}\text { Meningitis, epiglottitis } \\
\text { suppurative arthritis, otitis media } \\
\text { Patients are usually young children } \\
\text { Infections commonly bacteraemic }\end{array}$ \\
$\begin{array}{l}\text { Capsulated, } \\
\text { other types }\end{array}$ & $1-2 \%$ & $\begin{array}{l}\text { Rarely incriminated as pathogens, but } \\
\text { all } 5 \text { types have sometimes caused } \\
\text { diseases as above }\end{array}$ \\
$\begin{array}{l}\text { Non- } \\
\text { capsulated }\end{array}$ & $50-80 \%$ & $\begin{array}{l}\text { Exacerbations of chronic bronchitis, etc } \\
\text { Also otitis media, conjunctivitis } \\
\text { Patients are commonly adults } \\
\text { Infections rarely bacteraemic }\end{array}$ \\
\hline
\end{tabular}

serotypes.

Although all the serotypes (a-f) are virulent for mice and have at times infected humans, the $b$ type is far more common and life threatening, especially to young children. The majority of studies done nowadays on Haemophilus influenzae are therefore focused on the $b$ type. Of the many diseases caused by the Haemophilus influenzae type b (Hib) meningitis is by far the more serious and common. A survey done in Detroit by Dajani ${ }^{3}$ et al in 1974 showed that out of 292 children suffering from Haemophilus influenzae infections only one case could be attributed to the $d$ type. Meningitis accounted for $51 \%$ of 
the manifestations, epiglottitis (17\%) and pneumonia (15\%) were the next most frequent cases. Most of the patients were between three months and four years old and therefore, the clinical importance of Hib infections lies in the first few years of life. This is not to say that

Table 2. Structure of Haemophilus influenzae capsular polysaccharides

\begin{tabular}{|c|c|}
\hline Type & Structure \\
\hline a & $\rightarrow 4)$ - $\beta$ - D - Glc - $(1 \rightarrow 4)$ - D - ribitol - $\left(5-\mathrm{PO}_{4}^{-} \rightarrow\right.$ \\
\hline b & $\rightarrow 3)-\beta-D$ - Ribf - $(1 \rightarrow 1)-\mathrm{D}$ - ribitol - $\left(5-\mathrm{PO}_{4}{ }^{-} \rightarrow\right.$ \\
\hline c & 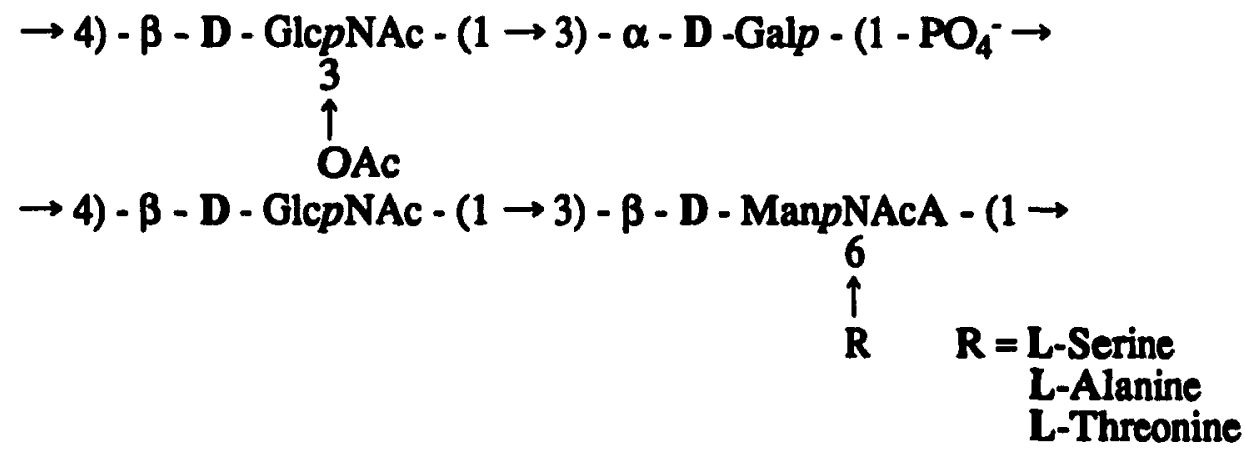 \\
\hline e & $\rightarrow 3)$ - $\beta$ - D - GlcpNAc - $(1 \rightarrow 4)$ - $\beta$ - D - ManpNAcA - $(1 \rightarrow$ \\
\hline e & $\begin{array}{c}\rightarrow 3) \text { - } \beta \text { - D - GlcpNAc - }(1 \rightarrow 4) \text { - } \beta \text { - D - ManpNAcA - }(1 \rightarrow \\
3 \\
\uparrow \\
2 \\
\beta-D \text { - Fruf }\end{array}$ \\
\hline $\mathbf{f}$ & $\begin{array}{c}\rightarrow 3) \text { - } \beta \text { - D - GlcpNAc - }(1 \rightarrow 4)-\alpha-D \text { - GalNAc - }\left(1-\mathrm{PO}_{4}^{-} \rightarrow\right. \\
3 \\
\uparrow \\
\text { OAc }\end{array}$ \\
\hline
\end{tabular}

older patients are not infected by Hib. Persons of any age can be infected, but these cases are usually associated with other debilitating conditions such diabetes and alcoholism.

Meningitis has, as a result, been the most thoroughly studied of the Hib infections. In the United States one in $\mathbf{5 0 0}$ children will contract Hib meningitis (about ten thousand cases per year) in the first few years of their lives and about four hundred will die'. 
Recently researchers have also started to worry about the contagiousness of the Hib infections and have tried to devise an efficient prophylaxis for secondary cases. Antibiotic treatment (usually chloramphenicol and ampicillin) for meningitis is reasonably effective; the mortality rate is less than $5 \%$ today compared to the virtually $100 \%$ mortality rate in the preantibiotic era. However, the neurological aftermaths suffered by the survivors belittle the success rate. A follow-up study of fifty meningitis convalescents showed that almost $28 \%$ had some serious handicaps such as hearing loss, language disorder, mental retardation and cerebral palsy. Some patients $(9 \%)$ were normal but suffered from behavioural problems such as hyperactivity and aggressiveness. Hib meningitis is therefore very serious and will each year kill or permanently scar many children; actually it is a leading cause of acquired mental retardation. The other diseases mentioned in Table 1 may contribute significantly to the mortality rate but are not as well assessed. Antibiotics, the only treatment available may not be very effective in the future as strains of ampicillin resistant Hib bacteria are now frequently being isolated. The desirability for a suitable vaccine against the Hib infections is therefore obvious ${ }^{1}$.

\subsection{Immunization with PRP alone}

The logical choice for a vaccine against the Hib infection is the capsular polysaccharide of the bacteria since it is the main factor for virulence of this species. Polysaccharide vaccines have already been shown to be efficient. For example, innoculation with the capsular polysaccharide of streptococcus pnewmoniae resulted in efficient protection against these bacteria. A clinical evaluation of purified PRP as a vaccine against Hib infections was performed in two countries (USA and Finland) on approximately 60,000 volunteers ${ }^{4}$. The following conclusions could be drawn. Adults responded favorably (even to low doses of PRP) with high titers of long lasting anti-PRP antibodies. Immunization sometimes persisted for several years. However, children of ages 
two to five produced a lower but still protective response, with the youngest giving the lowest titers of antibodies. Most infants less than 18 months of age failed to give any immune response. Only a small percentage of immunized children responded with low levels of antibodies. Furthermore, these levels decreased steadily and lasted only a few weeks and administration of a second dosage also failed to raise any booster effects. The most important defect of the PRP vaccine is due to its failure to immunize the population most at risk since the maximum incidence of Hib meningitis is around nine months. The failure to immunize infants with purified PRP is not well understood and several explanations have been put foward. The generally accepted one is based on the fact that most polysaccharide immunogens are T-cell independent.

\subsection{Simplified overview of the immune system ${ }^{6}$}

The immune system consist of a complex network of cells (lymphocytes and macrophages) and molecules (antibodies and complement) circulating through the bloodstream and lymphatic system. Its main function is to recognize foreign invaders and destroy or deactivate them. When the body is challenged by a foreign material (antigen or immunogen), the formation of specific immunoglobulin protein molecules (antibodies) and specific reactive cells (e.g killer cells) is induced. Both will react with the antigen resulting in its destruction. The cell-mediated response is produced by the T-lymphocytes (formed in the Thymus), whereas the B-lymphocytes (Bone marrow) are responsible for the antibody production or a humoral response. Both types of lymphocytes have to be assisted by macrophages to give a functional immune response.

\section{T-cell independence}

Activation of the B-lymphocytes by an antigen to produce antibodies requires the participation of the T-lymphocytes. However, some antigens, usually polymers like 
polysaccharides and poly(D-amino acids) do not require the assistance of the T-cells and are thus termed T-independent. It has been postulated that an immunologically naive animal (e.g an infant) has mainly IgM receptors for binding antigens. When invaded by a T-dependent antigen (or immunogen), the T-cells activate the IgM precursors to produce both an IgM and an IgG response. A T-independent antigen will not trigger the T-lymphocytes and hence only an IgM response is raised. An important property of the IgM response to the T-cell independent antigens is that memory cells are not produced. The generation of mernory cells enables the immune system to recognise the antigen and to raise an anamnestic response on a subsequent encounter by the same antigen. Therefore, an infant under 18 months immunized with purified PRP will not be protected against the disease and even a booster dose will have no effect. On the other hand adults are said to be more immunologically mature as their immune system already contain both IgG and IgM precursors. The IgG precursors are thought to have been acquired through natural exposure to the bacteria itself or to other cross reacting bacterial polysaccharides. (See chapter 3). This hypothesis is further confirmed by the fact that infants convalescing from Hib meningitis do produce significant doses of anticapsular antibodies?

It has thus been concluded that PRP is a hapten, i.e. by itself it is weakly immunogenic but combination with a carrier molecule allows the immunogenicity to be fully expressed. Numerous approaches have been attempted to make PRP more immunogenic. The findings that infants surviving Hib infections produce anti-PRP antibodies have led some researchers to use the whole cell of Hib in an effort to generate an immune response. The virulence of the bacteria was attenuated by using temperature sensitive strains; i.e., at physiological temperature the bacteria cannot survive very long and also fail to reproduce. It was hoped that the bacteria would confer its immunogenicity and then die without adversely affecting the vaccinee? Others have attempted to identify the 
other capsular components present together with PRP and monitor their immunogenicity. Lipolysaccharides and proteins have so far been isolated and some of the latter have been found to be immunogenic in humans ${ }^{8}$. These approaches are still in their infancy and much work remains to be done in order to draw any concrete conclusions.

\subsection{Conjugate vaccines (non-covalent)}

The most active and undoubtedly the most successful approach to date is the development of carrier-hapten or conjugate vaccines. A hapten like PRP is antigenic but weakly immunogenic. Combining it through covalent or non covalent bonding with a carrier molecule (usually a protein antigen) usually enables the immunogenicity of PRP to be fully expressed. Anderson et al ${ }^{9}$ have isolated PRP non-covalently associated (possibly by electrostatic interactions) with other envelope constituents, namely a protein and tested the conjugate for immunogenicity. They found that the complex showed promise as an immunogen. Two year old children were innoculated with either PRP or the complex and the antibody levels were monitored. The complex showed appreciably higher levels of antibodies than PRP alone, and the authors therefore concluded that there was a weak carrier effect. Similarly Kuo ${ }^{10}$ from Lederle Laboratories has combined PRP with the Bordetella pertussis protein in an attempt to gain an adjuvant effect from the pertussis molecule. The combination proved to be successful in a clinical trial involving about 350 children ranging from two months to six years of age. It was demonstrated that most infants responded favorably to the vaccine and even two month old infants produced antibodies levels that were then considered protective $(0.15 \mu \mathrm{g} / \mathrm{ml})$. However Makela ${ }^{11}$ later suggested that a level of $1.0 \mu \mathrm{g} / \mathrm{ml}$ is needed for protection. Other systems were tested in order to find any adjuvant effects. Most of them involve potentially toxic adjuvants and human trials have not been attempted. 


\subsection{Conjugate vaccines (covalent)}

Others have chosen to form covalent bonds between the protein carrier and PRP. The advantages of such a system are numerous, e.g the greater stability of the conjugate. The rajor difficulty in the formation of covalent conjugate is that PRP do not have any reactive moieties such as carboxylic acids, amino groups or aldehydic functions which can react with the amino or carboxylic groups of the proteins. Furthermore, the phosphodiester linkages are both acid and base labile. Therefore the coupling has to done under very mild conditions. Schneerson et $\mathbf{a l}^{12}$ have linked PRP to a protein according to the following approach. The polysaccharide was activated with cyanogen bromide forming an electriphilic cyanate ester and to the latter was added the adipic acid dihydrazide derivative of the protein. (Scheme 1). The dihydrazide molecule served as a spacer between PRP and the protein. If the reaction between the protein and the cyanate ester was attempted without the spacer, negligible coupling occured. The conjugate vaccine was found to be very effective in animal trials; the immunogenicity was greater than for PRP alone and, as expected, it was also better than for a non-covalent complex. The following observations were also made. The choice of the carrier molecule was crucial. If the functionalized PRP molecule was coupled to another PRP molecule or with another bacterial polysaccharide (pneumococcus type 3), no immunogenicity was detected although the PRP-protein conjugates and the PRP-polysaccharide conjugate had comparable molecular weights. It was thus concluded that the molecular weight of the conjugate was not an important factor for immunogenicity whereas for PRP alone the molecular weight was found to be critical. However, PRP-protein conjugates prepared from T-dependent antigens such as diphtheria toxin showed some T-dependent character. A second injection induced an increase in the antibody levels (booster effect). The authors thus suggested that by coupling to a protein carrier, PRP was converted to T-dependent immunogen. Although the authors claimed that the conjugate was non-toxic (lethal dose $>100 \mathrm{mg} / 25 \mathrm{~g}$ mouse) and non-mutagenic, clinical 
trials have not yet been performed due to the possible adverse reactions of the adipic acid hydrazide spacer.
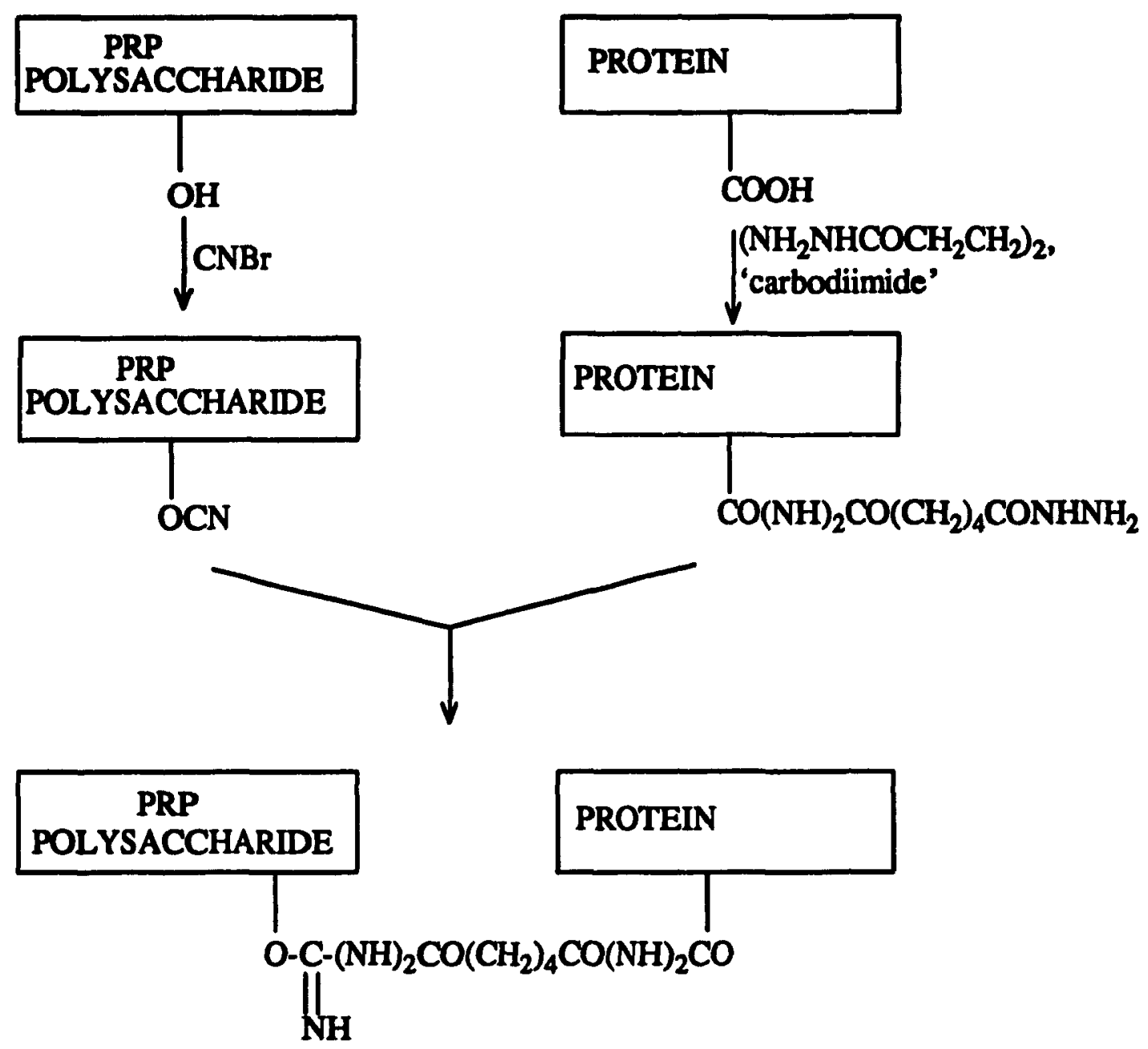

Scheme 1

A similar approach by Tai13 et al utilized a 6-aminohexanoic acid spacer between PRP and the serotype II protein of group B meningococcus. This conjugate was also prepared by prior cyanogen bromide activation of the PRP followed by addition of the spacer and finally the protein in the presence of carbodiimide. In this case, clinical trials were done and the results obtained were promising. Children $\geq$ one year of age responded 
with antibodies titers of at least $1.0 \mu \mathrm{g} / \mathrm{ml}$ after two $10 \mu \mathrm{g}$ doses but children less than 1 year of age did not respond as well. However, doubling the dosage to $20 \mu \mathrm{g}$ induced protective antibody levels $(1.0 \mu \mathrm{g} / \mathrm{ml})$ in children as young as 8 months of age. Unfortunately the higher dose was not very well tolerated. Many of the vaccinees developed high temperatures and some of them also suffered from fatigue and irritability. These side effects were all attributed to the vaccination. Infants younger than eight months did not respond at all.

All the conjugates mentioned in the previous paragraphs were prepared from a protein and the whole PRP polysaccharide. Anderson and others have chosen to use fragments of PRP instead. They suggested that fragments of PRP rather than the intact polymer might increase the T-character of the conjugate. This hypothesis has gained some support following the findings of Makela who reported that a conjugate made from fragments of a dextran gave a higher secondary response than the one prepared from the whole polymer. As mentioned earlier, PRP does not have any reactive moieties. However, if the polymer is hydrolyzed with acid $\left(0.01 \mathrm{~N} \mathrm{H}_{2} \mathrm{SO}_{4}, 100^{\circ} \mathrm{C}, 6 \mathrm{~min}\right)$ oligomers of PRP with hemiacetal termini are obtained (Scheme 2). Fractionation of the mixture by gel chromatography yielded chains of varying lengths which were classified as small, medium or large size oligomers depending on their retention times. The latter were then linked to the amino groups of a protein under reductive amination conditions $\left(\mathrm{NaCNBH}_{3}, \mathrm{pH} 8\right.$, $37^{\circ} \mathrm{C}, 18$ days). (Scheme 3). All three preparations were found to be more or less equally effective in rabbits. The major advantage in this type of conjugate is that the use of any foreign spacer between the protein and PRP is unnessary thus avoiding any immunological side-reaction due to the spacer ${ }^{14}$.

Several proteins have been evaluated as carriers, namely diphtheria toxin (DTx), its 


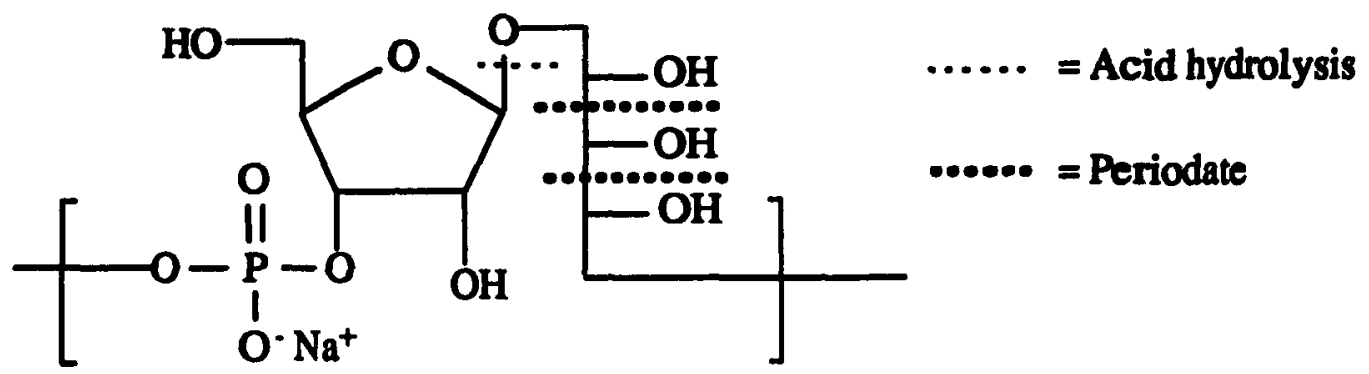

Scheme 2
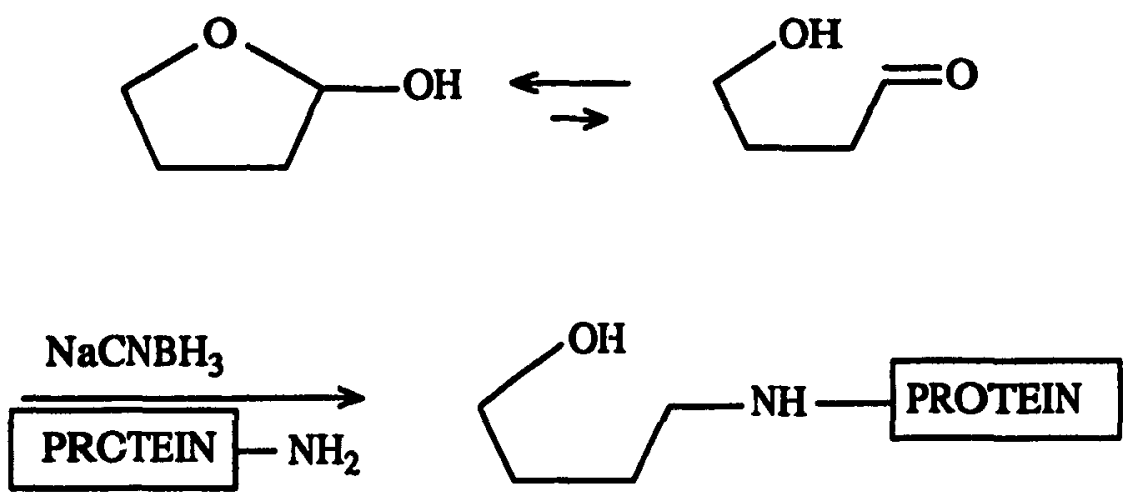

Scheme 3

cross-reacting and non-toxic derivative CRM197 (Dcr) and diphtheria toxoid (DTd) ${ }^{16}$. In clinical trials, preparations consisting of 3-10 units of PRP coupled to these proteins have been shown to elicit an immune response. The DTx protein is a potential pathogen and has to be detoxified with formaldehyde before use; but unfortunately, it often reverts to its toxic form upon storage. The non toxic CRM197 and the stably detoxified DTd were therefore favored. Administration of the conjugate vaccine to infants ranging from 19-23 months of age induced levels of antibodies that were comparable to those of vaccinees receiving PRP alone. In contrast to PRP, a second dose elicited higher response which had a significant IgG component. Similarly, 12-16 months old infants showed high primary and secondary responses which were of IgG nature. The Dcr-PRP conjugate also induced a higher 
secondary rise than the DTd-PRP conjugate ${ }^{15}$ and was thus favored by the authors. They also compared the response induced by PRP, PRP non-covalently complexed to Hib outer membrane proteins and PRP-Dcr in two year old children ${ }^{16}$. The latter was found to be far superior than the two former.

In a study by the same authors, ${ }^{17}$ infants were given the Dcr-PRP vaccine at 2,4 and 6 months of age. At the end of 6 months, the antibody rises were spectacular. The levels were almost 3 times higher than in controls given PRP alone. The pattern of the antibody production also merits some consideration; after the first dose at 2 months, the level of antibodies actually decreased slightly. However, after the second dose, the antibody levels rose sharply and the rise was even more pronounced after the third dose at 6 months. The nature of the response was also studied in greater details. After the second injection, the IgG component rose suggesting an anamnestic response; furthermore, it was found that PRP alone was as effective as the conjugate as long as the subject was first primed with the conjugate vaccine. The authors have therefore proposed a immunization protocol in which infants are primed with a Dcr-PRP conjugate in the early months of life, followed by several booster doses with PRP alone.

In a different approach for obtaining oligosaccharides of PRP, Anderson et al..$^{18}$ made use of sodium periodate (Scheme 2) to cleave the vicinal hydroxyls of the ribitols to give oligomers with one or two aldehydic extremities which was then attached to the Dcr protein by reductive amination $\left(\mathrm{NaCNBH}_{3}, \mathrm{pH} 8,37^{\circ} \mathrm{C}, 5\right.$ days). They reasoned that a free aldehyde might be more reactive than one in the hemiacetal form. Gel chromatography yielded two oligomer fractions with a degree of polymerization (DP) of 8 and 20. In contrast to the acid-hydrolyzed PRP, the structural requirement was more stringent. The DP 20 oligomer was found to be more immunogenic in 1 year old infants. 


\subsection{Bigeneric Spacer Conjugate Vaccines}

Marburg and coworkers ${ }^{19}$ introduced a new concept for the synthesis of covalent polysaccharide-protein conjugates. The term "bigeneric spacer conjugate", in contrast to "monogeneric spacer conjugate" (conjugates described earlier), was coined for this approach (Scheme 4). This system evolved from the need of ascertaining that the bond
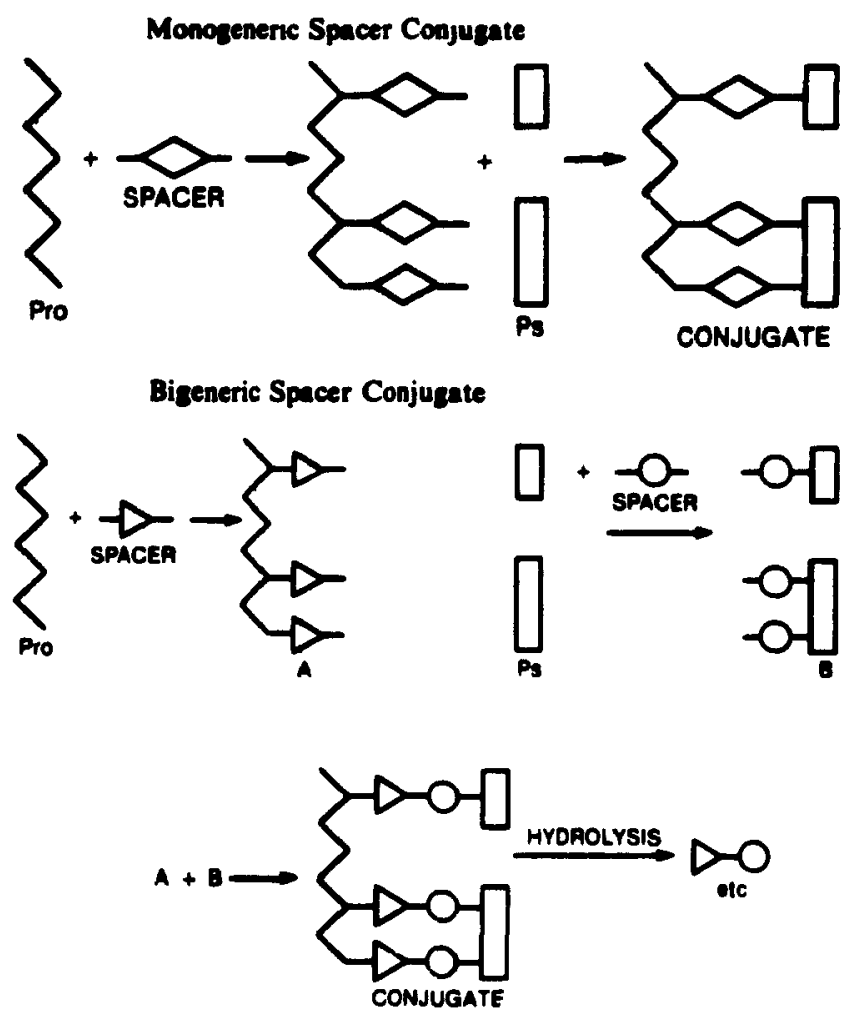

Scheme 4

between the protein and PRP is indeed covalent. The nature of the linking bond in the previously described conjugates could not be identified with certitude and instead, its covalency was indirectly inferred. In this new approach, both the protein and PRP are functionalised with a bifunctional spacer molecule. The remaining valency is selected in such a way that they can react with each other to form a stable covalent bond. Furthermore, the bigeneric spacer molecule is stable to acidic conditions which will degrade the conjugate. The presence of this molecule will therefore prove that the conjugate is indeed 
covalently linked. The chemistry is summarized in Scheme 5. The degradation product, aminoacid 6 containing a thioether linkage, could be easily assayed both qualitatively and quantitatively.

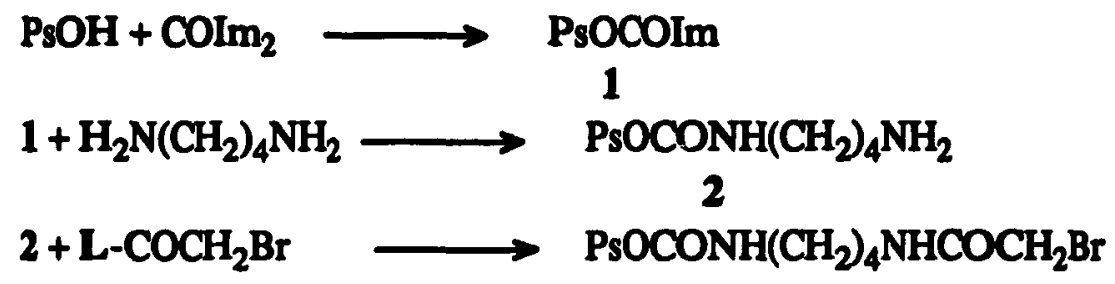

$\mathrm{CH}_{3} \mathrm{CONH}$

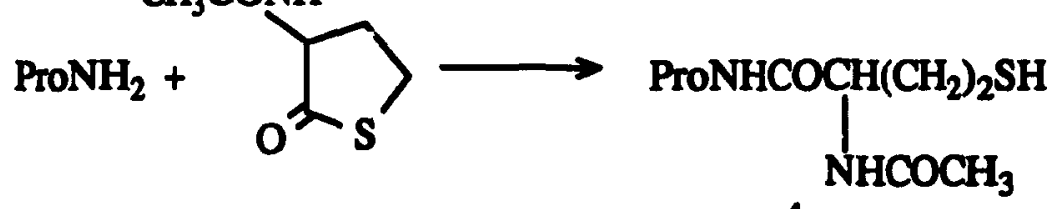
4

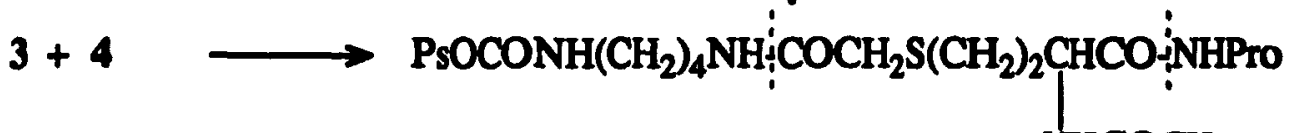
$\mathrm{NHCOCH}_{3}$

\author{
5 \\ $5+\mathrm{H}_{3} \mathrm{O}^{+} \longrightarrow \mathrm{HO}_{2} \mathrm{CCH}_{2}-\mathrm{S}\left(\mathrm{CH}_{2}\right)_{2} \underbrace{\mathrm{CHCOOH}}_{6}$ \\ Abbreviations:- Ps= Polysaccharide, $\mathrm{Im}=$ imidazole, $\mathrm{L}=$ leaving group \\ Pro $=$ Protein
}

Scheme 5

A conjugate of PRP (whole polymer) and the outer membrane protein of group B Nisseria meningitidis was prepared and characterized by the method described in the last paragraph ${ }^{20}$. Granoff and coworkers then administered this conjugate to 117 children ranging from 2-83 months of age. Nearly all the children produced protective levels of antibodies with significant levels of IgG which were boostable by either the conjugate or PRP alone. 


\subsection{Conchusions}

In summary it can be said that PRP conjugates, especially the covalently-linked ones, have been proven to be effective in conferring immunogenicity in infants who are unresponsive to the PRP polysaccharide alone. However, only the short term effects of these conjugates are known. Potentially toxic reagents are used in the synthesis of the conjugates and new antigenic determinants are created in the process. The biologic consequences of exposure of these conjugate vaccines to humans are still undetermined and, according to one author, licensure of these vacccines is still years away ${ }^{21}$. Also, a direct comparison of the various conjugates have not yet been performed. Therefore, the efficacy and safety of one relative to another remains largely unknown.

So far two broad classes of covalent PRP conjugates have been described. Both are reasonably safe and are capable of raising useful titers of protective antibodies even in young children. The first ones are the conjugates prepared from the intact polymer such as the ones described by $\mathrm{Tai}^{13}$ and Granoff ${ }^{19,20}$. The main feature of these conjugates is that a spacer is necessary to link the entire polysaccharide to the carrier molecule. Also, the polysaccharide will be inevitably cross-linked to the protein carrier at random points along its backbone. Any antibody response against the spacer may lead to an unnecessary and even toxic immunological side-reactions. For example, the conjugate with an adipic acid dihydrazide spacer described by Schneerson ${ }^{12}$ in 1980 has not, to our knowledge, undergone clinical trials; it is plausible that the dihydrazide spacer could not be proven to be totally innocuous in humans.

The other class of PRP conjugates is the one described by Anderson ${ }^{14}$. 18, :vhere fragments of the polysaccharide are used instead of the whole polymer. The advantages are numerous; it has been reported that fragments of a polysaccharide antigen have more 
T-dependent character. Moreover, the spacer between the oligomer to the protein is derived from PRP itself thus lessening any spacer-mediated side effects. Two methods for generating fragments of PRP have been described. In the first one, PRP is depolymerised with acid to give oligomers with one reducing terminus (assuming that the polymer is totally linear). The resulting conjugate will thus consist of the protein attached to C-1 of a ribitol whose C-3 is linked to the C-5 of another ribitol via a phosphate group. Anderson also reported that the oligosaccharides had between three and ten units. It is not likely that the composition of the mixture will be consistent from one batch to the other. The vaccine efficacy may, as a result, also vary.

Egan and co-workers ${ }^{22}$ have done ${ }^{31}$ P NMR studies on the end groups of the PRP polysaccharide and have found that in addition to an intense peak at $1.09 \mathrm{ppm}$, weaker downfield signals at $3.95,18.85$ and $20.83 \mathrm{ppm}$ were also detected. By comparison with known compounds, these signals were assigned to a terminal phosphate, a D-ribosyl 2, 3-cyclophosphate and a D-ribitol 4, 5-cyclophosphate respectively. These workers also showed that the terminal phosphates of model compounds could be converted to the cyclophosphate moiety with the aid of carbodiimide. However, one could envisage an acid catalyzed mechanism to accomplish the same transformation (Scheme 6). Therefore during

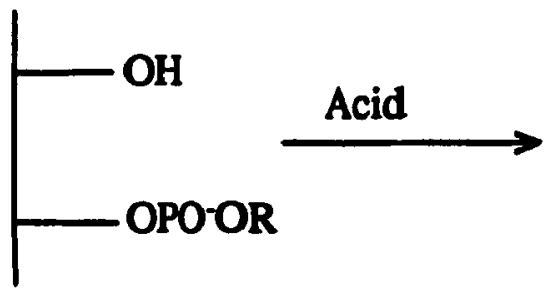

Scheme 6

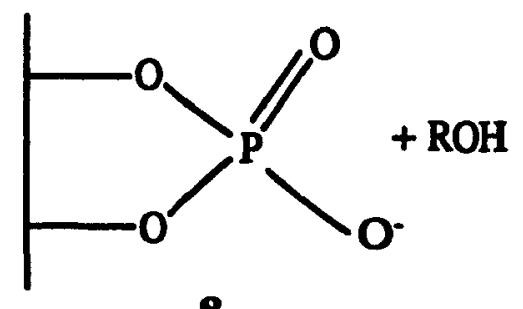

8

acid depolymerization, it is logical to expect the formation of a reasonable quantity of these cyclophosphates. Unfortunately no NMR studies have been performed on the acid 
hydrolyzed polymer to confirm this hypothesis. The cyclophosphate termini may not have any effect on conjugates prepared from the whole polysaccharide. On smaller fragments (3-10 units) the effect of these termini on vaccine efficacy and safety is not known.

The second approach which uses periodate to generate fragments of PRP by cleavage of the vicinal diols of the ribitol portion to give, after gel chromatography, oligomers with a degree of polymerization of 8 and 20 . These oligomers are thus very likely to have two aldehydic terminii which can thus bind to one or two separate protein molecules or both aldehydes can link to the same carrier forming a loop. It was determined that the conjugates were monomeric i.e. each aldehyde was bound to one protein molecule. However, the loop formation has not been excluded. The extent to which the polysaccharide is singly attached or doubly attached is also not known. Anderson also suggested that the doubly linked saccharides may be prevented from accessing the antigen-binding sites because of steric factors ${ }^{18}$. The activity of these conjugates were also size dependent in contrast to the acid-cleaved series. Many factors thus still remain unclear in these conjugates. 


\section{Chapter 2}

2.1 Aim and rationale of the project.

PRP or fragments of it has been shown by various workers to be a hapten, which when attached to various protein carrier molecules, has been found to induce protective levels of antibodies in infants under one year of age. The identity of the fragments and the conjugates obtained by the two reported procedures is not well defined. We thus sought an approach by which any ambiguity could be avoided, i.e present the hapten in a well defined form where the end-group composition and the chain length will be known. Anderson has already shown that conjugates of a 3-10 unit oligosaccharide were effective. Therefore the possibility exists that a few ribosyl-ribitol-phosphate units accessible through chemical synthesis (solution or solid-phase) would suffice. Moreover, our approach would allow us to positively correlate immunogenicity to the size of the hapten. We believe that the determination of the most antigenic hapten is important since it will enable the administration of smaller but optimal doses, which undoubtedly, will be beneficial.

Several groups, including one from our laboratory, have reported their efforts in this area. The earliest one was from Garegg and co-workers, where the synthesis of the following basic structures, the 1-O- $\beta$-D-ribofuranosyl-D-ribitol $9^{23}$ and its 5-phosphate $10^{24}$ were described. The latter had no immuriolugical activity. The spacer containing p-aminophenyl $\beta$-D-ribofuranoside 3-(D-ribit-5-yl phosphate) $11^{25}$ was also mentioned but no biological evaluation has yet been reported for this compound. Compound 9 was obtained by transesterification of orthobenzoate 12 with ribitol 13 followed by mercury (II) bromide mediated rearrangement of the resulting ribitol orthoester 14 to the corresponding $\beta$-ribofuranoside and finally, the appropriate deprotection sequence.

More recently, van Boom and coworkers reported in preliminary form ${ }^{26}$ the 


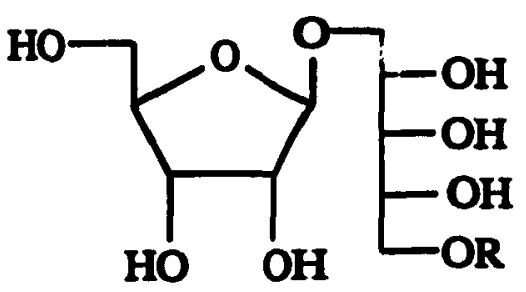

9. $\mathrm{R}=\mathrm{H}$ 10. $\mathrm{R}=\mathrm{PO}_{3}{ }^{2-}$

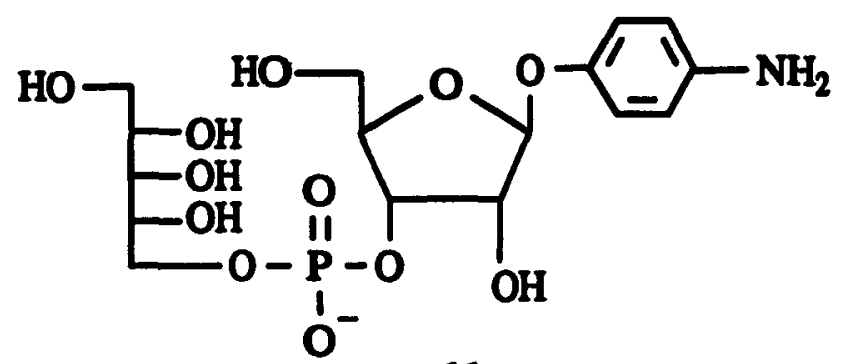

11

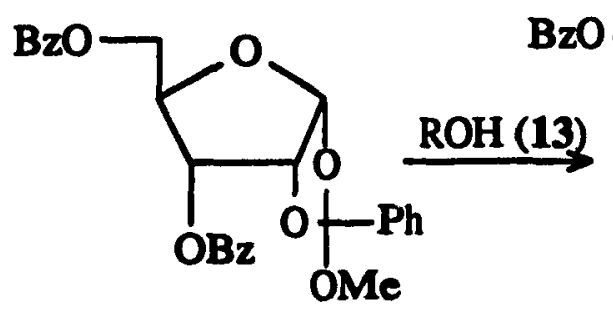

12

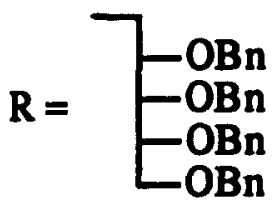

synthesis of a dimeric and trimeric unit carrying a glycinamide spacer 15 on the 5-hydroxyl of the terminal ribitol and also provided full experimental details of their work elsewhere 27. 28. They also reported that the trimer with the spacer showed immunological activity which was comparable to conjugates prepared from natural PRP. Soon after, Wang from our laboratory reported the synthesis of a tetramer ${ }^{29}$ of PRP via a very similar approach. A suitably functionalised dimer was coupled to another dimer giving the tetramer. Due to the presence of three chiral phosphate groups (i.e. 8 diastereomers), the TLC of the products appeared as numerous spots, some of which had identical $R f$ values as the starting materials. Purification was as a result almost impossible. A suitably protected ribose 
spacer was also described. Linkage of this spacer via a phosphate moiety to the tetramer on the $3^{\prime}$ position was also attempted ${ }^{30}$. Unfortunately, the products obtained from this reaction could not be characterized due to the use of large excesses of a reagent and the inability to purify the products. Not surprisingly, this hapten, when coupled to a protein showed no immunogenicity in animal trials.

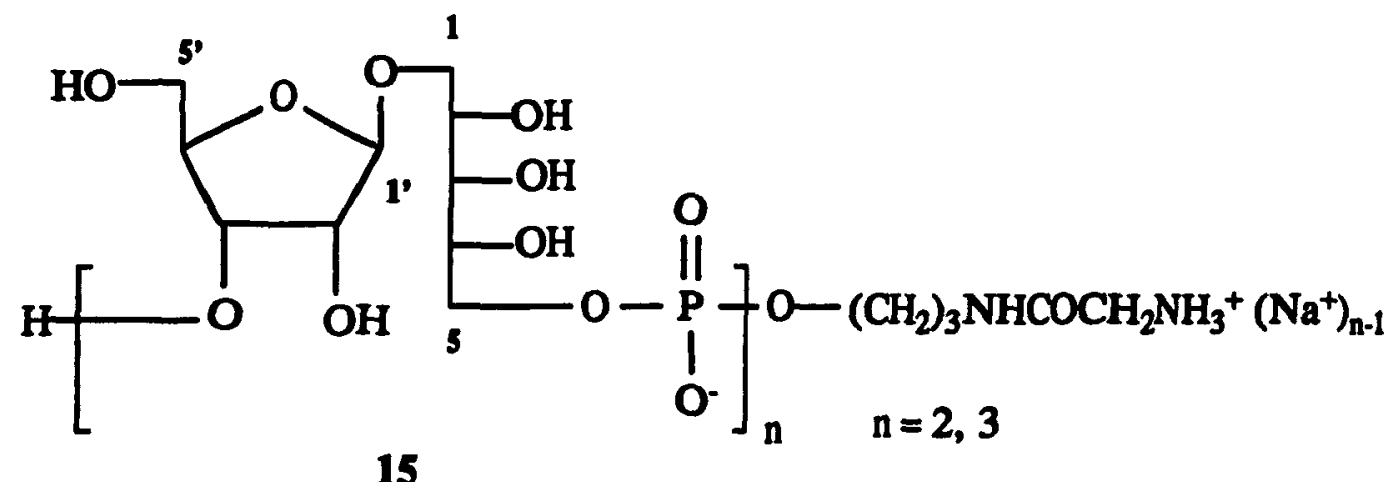

Both approaches had many common features. For example, the ribosyl-ribitol moeity was constructed by glycosidation of tetra-O-acetyl- $\beta$-D-ribofuranoside (or 2,3,5-tri-O-benzoyl 1-O-acetyl- $\beta$-D-ribofuranoside in van Boom's case) with a suitably protected ribitol. In the former the anomeric position was activated under Koenigs-Knorr conditions, whereas van Boom used trimethylsilyl triflate as glycosidation catalyst. The 2-0-acetyl or the 2-0-benzoyl groups provided the necessary neighbouring group participation to steer the incoming ribitol to the desired $\beta$-anomeric configuration.

Any syntheses of oligomers of the Hib polysaccharide has to take the following into consideration. Out of the seven hydroxyls that constitute the basic unit of the ribosyl-ribitol moiety only two, the $3^{\prime}$ and 5-OH, are necessary for chain elongation. (see 15). The differentiation of the two crucial hydroxyls should pose no problems because of their dissimilarity. However, the differentiation of the 2' and 3' hydroxy groups is not easy; Ogilvie et al ${ }^{31}$ have developed a methodology by which a ribonucleoside can be selectively 
tert-butyldimethylsilylated at the 2' and 5' sites in good yields. However, it appears that this reaction is not general; attempts by Wang ${ }^{30}$ failed to give any selectivity, perhaps due to the absence of the base which might furnish some directional effects.

In order to differentiate between the $2^{\prime}$ and the $3^{\prime}$ hydroxy groups both successful syntheses of the Hib oligosaccharides made use of Markiewicz protecting ${ }^{32}$ group, the tetraisopropyldisiloxane-1,3-diyl moiety, to selectively bridge the $3^{\prime}$ and 5' hydroxy groups (16). The free 2' hydroxy was then masked with a benzyloxymethyl (BOM) group since the bifunctional silyl moiety was unstable to the strongly basic conditions required to attach a benzyl group. It was found that the BOM group was not compatible with the amino group

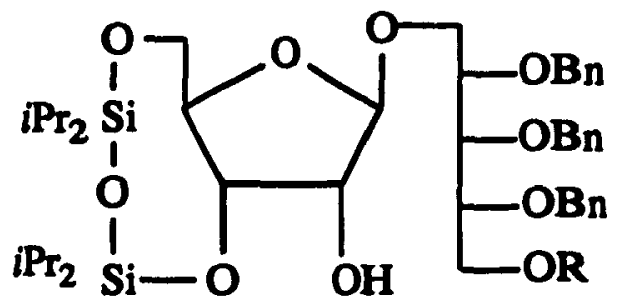

16

spacer used by van Boom ${ }^{28}$. During deprotection, the BOM groups liberated formaldehyde which reacted under reductive amination conditions with the spacer amino group to form the corresponding methyl and the dimethyl amine derivative. Desilylation followed by selective protection of the primary 5' hydroxy group as a tert-butyldimethylsilyl ether or the corresponding diphenyl derivative leaves the 3' hydroxy open for coupling to the 5-position of another suitably protected ribosyl-ribitol unit through a phosphate bond. Extensive protecting group manipulation is therefore required at a fairly late stage of the synthesis. Also, the use of a silyl ether to block the 5 ' hydroxy introduces another deprotection step later on: Both previous syntheses of fragments of PRP made use of phosphate protecting groups winich were cumbersome to remove. The methyl group in Wang's case required refluxing in tert-butylamine for $24 \mathrm{~h}$ and removal of the 0-chlorophenyl groups in van 
Boom's case required treatment with syn-pyridine-2-carboxaldoxime/ $/ N^{1}, N^{1}, N^{\beta}, N^{\beta}$ tetramethylguanidine for $48 \mathrm{~h}$. Therefore, we felt that the synthesis could be improved if the following could be achieved:

(1) differentiation of the 2 and 3 hydroxyls at an early stage so as to avoid the use of the expensive bifunctional silyl blocking group;

(2) avoidance of the use of BOM groups should the need to use spacers with terminal amino groups arise;

(3) protection of all non-participating hydroxyls as benzyl ethers to simplify the deprotection sequence; and

(4) use of a different phosphate protecting group which is easier to remove.

Inspired by earlier reports by Wang ${ }^{30}$ and Garegg ${ }^{23}$, we decided to make use of an orthoacetate such as $\mathbf{1 7}$ as starting intermediate for glycosidation. The use of this compound will allow us to meet all the requirements mentioned above. The advantages are numerous; the 1 and 2 hydroxy groups are selectively masked thus in effect differentiating between the 2 and the 3-hydroxyls of the ribose portion. Furthermore, the 1,2 orthoacetate can easily be converted to a 2-O-acetyl halo-ribofuranoside which can be coupled to the ribitol component under Koenigs-Knorr conditions and finally the resulting 2-O-acetyl group will provide the necessary neighbouring participation to give the proper anomeric stereochemistry.

The syntheses of various different 5-O-protected ribitols have already been described by Wang ${ }^{30}$, the ideal one in his case being the 2,3,4-tri-0-benzyl-5-0-pivaloyl ribitol $^{29}$, whereas van Boom used the corresponding 5-0-allyl derivative ${ }^{26}$. The choice of a protecting group for the $\mathbf{5}$ hydroxy of the ribitol portion merits some consideration. It was found ${ }^{30}$ that in order for glycosidation to occur successfully in terms of yields and desired 


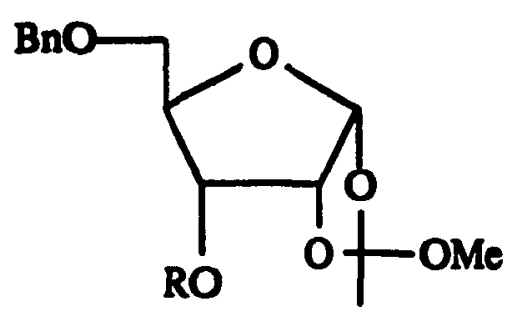

17

anomeric purity, the reaction had to proceed under acidic conditions; if neutral or basic silver salts such as silver (I) oxide and silver carbonate were used, an orthoester was isolated as a major product. For example, coupling the ribitol 18 with bromo-ribofuranoside 19 in the presence of silver carbonate resulted in the formation of orthoester 20 exclusively ${ }^{33}$. Similarly, acidic silver catalysts such silver perchlorate yielded an orthoester if the reaction medium was buffered with an acid scavenger such as tetramethylurea or sym-collidine. The use of acidic silver salts precludes the use of acid-labile groups such as trityl or 4-methoxy benzyl groups as was demonstrated by Wang. We therefore protected the 5 hydroxyl of the ribitol as its allyl ether as it is stable to a wide range of conditions. Since the 3 hydroxy group of the orthoester has to be temporarily blocked during the glycosidation, we again opted for its corresponding allyl ether thus allowing one single deprotection to free both crucial hydroxyls.

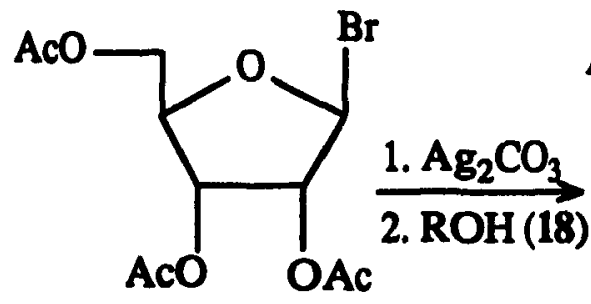

19

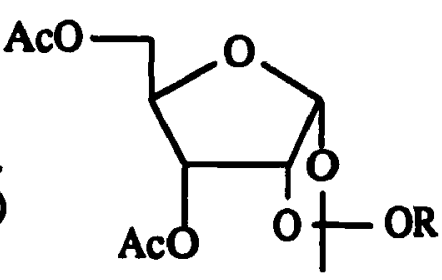

20

\subsection{Synthesis of the orthoacetate.}

The orthoester was synthesized as follows. Benzylation of the known 2,3-O-isopropylidene methyl ribofuranoside $21^{34}$ with benzyl bromide, sodium hydride and 
tetra-n-butylammonium iodide 35 gave the fully protected compound 22 in $96 \%$ yield.

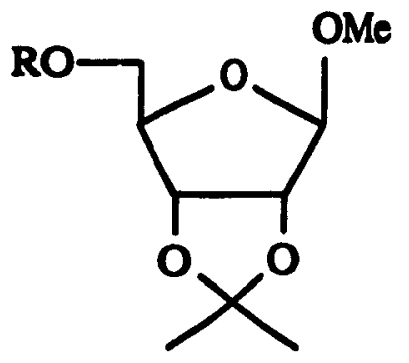
21. $R=H$

22. $R=O B n$

Conversion of 22 to triacetate 24 was achieved in a two-step one pot reaction. The hydrolyzable functions were removed by the action of an aqueous solution of acetic acid at $85^{\circ} \mathrm{C}$; the water and acetic acid were then removed by several coevaporations with toluene. Acetylation of resulting triol 23 with acetic anhydride, pyridine and DMAP yielded 24 as an anomeric mixture $(\sim 6: 4 \beta / \alpha)$ in quantitative yields. The direct acetylation from 22 using a mixture of acetic acid, acetic anhydride and an acid catalyst was also attempted. However, the isolation of the desired product required chromatography and was not amenable to large scale reactions. The triacetate 24 was then treated with a solution of anhydrous hydrogen chloride in dry methylene chloride. Evaporation of the solvent afforded the unstable chloro riboside $\mathbf{2 5}$ which was used without purification in the following step.

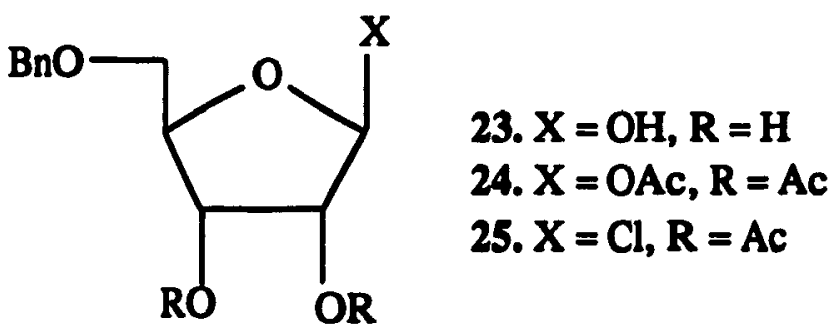

Reaction of $\mathbf{2 5}$ with dimethylformamide dimethyl acetal according to the procedure of Hanessian and Banoub ${ }^{36}$ afforded the orthoester 26 in good yields. The 3-O-acetyl group was then transformed to the corresponding allyl ether in another two-step one pot sequence. Hydrolysis of the acetate group using a catalytic amount of sodium methoxide in methanol gave an alcohol which was then converted to its allyl ether 27 using sodium hydride, allyl 
bromide and a catalytic amount of tetra-n-butylammonium iodide. No chromatographic separation was necessary for the compounds described except on the final orthoacetate 27.

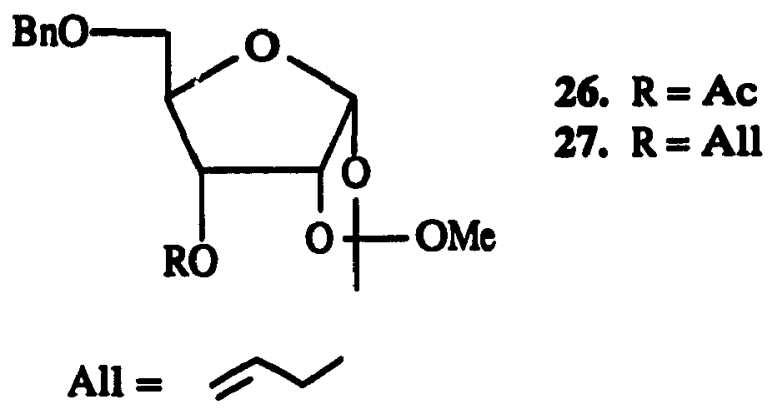

\subsection{Synthesis of the ribitol}

The right appendage of PRP, i.e the ribitol substrate was prepared according to the procedure of Wang ${ }^{30}$. Acid-catalyzed reaction of ribose with ethanethiol gave the corresponding dithioacetal which was then selectively monomethoxytritylated at the 5-position giving 28. Benzylation of the triol followed by detritylation gave the requisite intermediate 30. Allylation of the 5-hydroxyl gave the fully protected dithioacetal 31 which was then treated with mercury (II) chloride and mercury (II) oxide in aqueous acetone to yield an aldehyde which was without purification, reduced with sodium borohydride to the required ribitol 32 in good yields. The ribitol could be purified by Kugelrohr distillation.

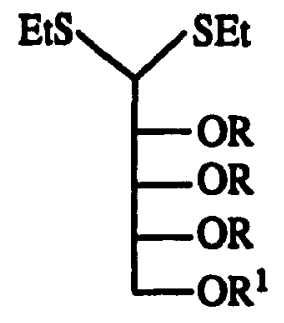
28. $R=H, R^{1}=M M T$
29. $R=B n, R^{1}=M M T$
30. $R=B n, R^{1}=H$
31. $R=B n, R^{1}=$ All

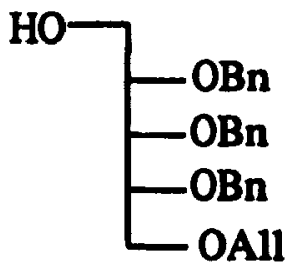

32

Although this approach is not very efficient, we did not improve it until at a later stage as the dithiocaetal 30 was donated to us in sufficient amounts by Dr. Y. Upeslacis of Lederle Labortatories. The fully protected dithioacetal 31 could be prepared more 
efficiently from methyl-2,3-O-isopropylidene- $\beta$-ribofuranoside 21. Allyiation of the 5 hydroxy group yielded the fully protected ribofuranoside $\mathbf{3 3}$ and the acid hydrolysis of the isopropylidene group in the presence of methanol gave the diol 34 which was then reacted with ethanethiol and zinc chloride to give the dithioacetal 35. Direct reaction of $\mathbf{3 3}$ with ethanethiol/zinc chloride also gave 35, albeit in lesser purity. Benzylation under standard conditions yielded the fully protected dithioacetal which was spectroscopically ( ${ }^{1} \mathrm{H}$ NMR) indistinguishable from allyl ether 31 prepared earlier.

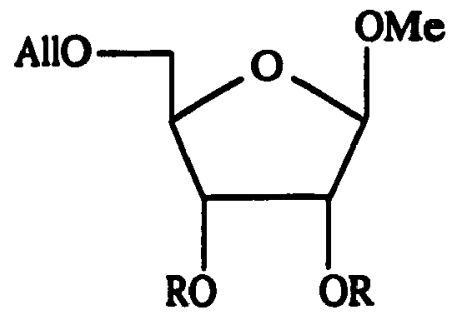

33. $\mathrm{R}=\mathrm{CMe}_{2}$

34. $\mathrm{R}=\mathrm{H}$

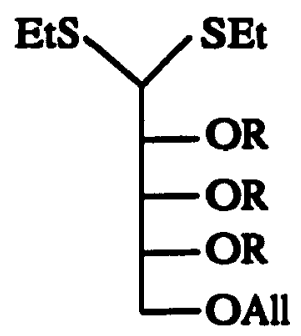

35. $\mathrm{R}=\mathrm{H}$

31. $\mathrm{R}=\mathrm{Bn}$

\subsection{Glycosidation}

With both key intermediates in hand, the construction of the ribose-ribitol bond was attempted using two methods. The first one involved transesterification with the ribitol (as in Garegg synthesis) followed by mercury (II) bromide mediated rearrangement to the glycoside. In our hands, this approach failed due to inability to effect the transesterification. Therefore, the other alternative which involved the conversion of orthoacetate 27 to the corresponding chloro-ribofuranoside 37 followed by Koenigs-Knorr glycosidation, was selected. Thus, treatment of the orthoester 27 with trimethylsilyl chloride ${ }^{37}$ gave 36 in excellent yields. The ${ }^{1}$ H NMR of the crude product showed the disappearance of the methyl and the methoxy singlets and the anomeric proton appeared as a singlet indicating that the chlorine was in the $\beta$ anomeric configuration. This chloride was then without purification added to silver perchlorate and 4A molecular sieves in acetonitrile at $-40^{\circ} \mathrm{C}^{38}$. The formation of a silver chloride precipitate was almost instantaneous. Addition of ribitol 32 to the mixture then gave the $\beta$-adduct exclusively in $80 \%$ yield. The 
identity of 37 was confirmed by ${ }^{1} \mathrm{H}$ NMR and ${ }^{13} \mathrm{C}$ NMR. Only a sharp singlet was observed at $4.90 \mathrm{ppm}$ and $105.2 \mathrm{ppm}$ respectively indicating that only the desired anomer was present. The 2'-0-acetyl group was then hydrolyzed with sodium methoxide and the resulting alcohol benzylated to give our target molecule 38 where all the non-participating hydroxyls were benzylated.

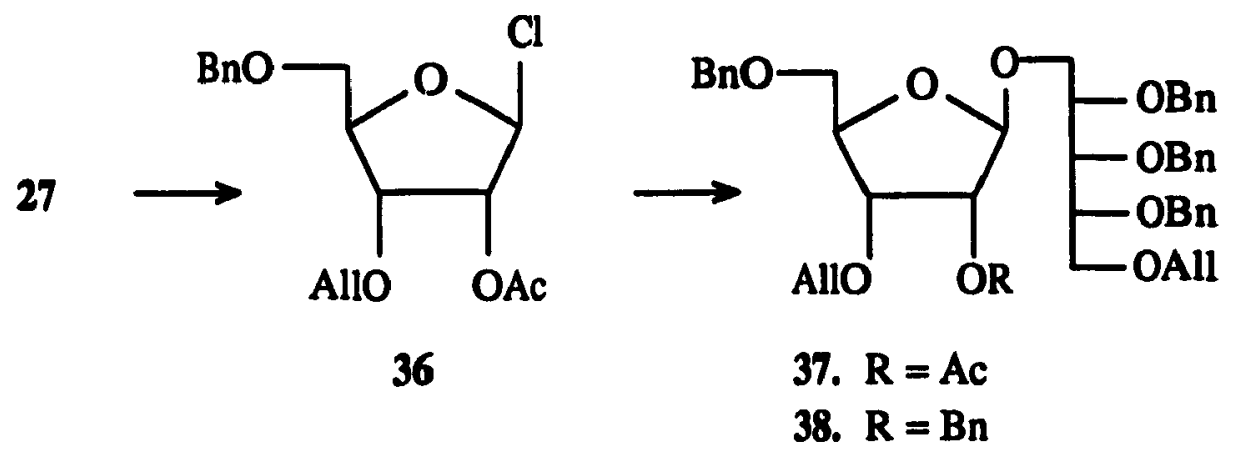

The direct coupling of the ribitol 33 to the orthoacetate 27 was also attempted. We speculated that the reaction of the orthoester with trimethylsilyl triflate (TMSOTf) could give the oxocarbonium-triflate ion pair 39 which could then be trapped with the ribitol.

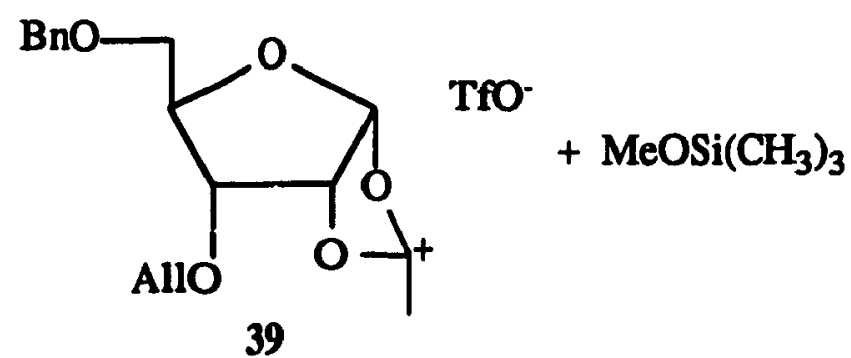

Neighbouring participation would again provide the desired stereochemistry. Thus, one equivalent of TMSOTf was added to a solution of the orthoester in methylene chloride. TLC monitoring showed that after one hour at it all the starting material was consumed and a new more polar spot, presumably the hydrolyzed carbonium ion, was observed. The ribitol was then added. Unfortunately, only small amounts of the required product was detected on TLC; therefore, this approach was not pursued any further. 
The two allyl groups were then removed by Corey's ${ }^{39}$ method in which the allyl ethers were first isomerised to their vinyl counterparts 40 by the action of tris(triphenylphosphine)rhodium(I) chloride in refluxing aqueous ethanol. ${ }^{1} H$ NMR of the crude mixture indicated that the allyl groups have been indeed converted to the vinyl ethers which existed as a mixture of cis-trans isomers. Oxymercuration with mercury (II) chloride and mercury (II) oxide in aqueous acetone ${ }^{40}$ yielded the unstable hemiacetals which in situ decomposed to the desired diol 41 . In our hands, the yields obtained in this reaction were not very satisfactory (55-65\%), an alternative was therefore sought.

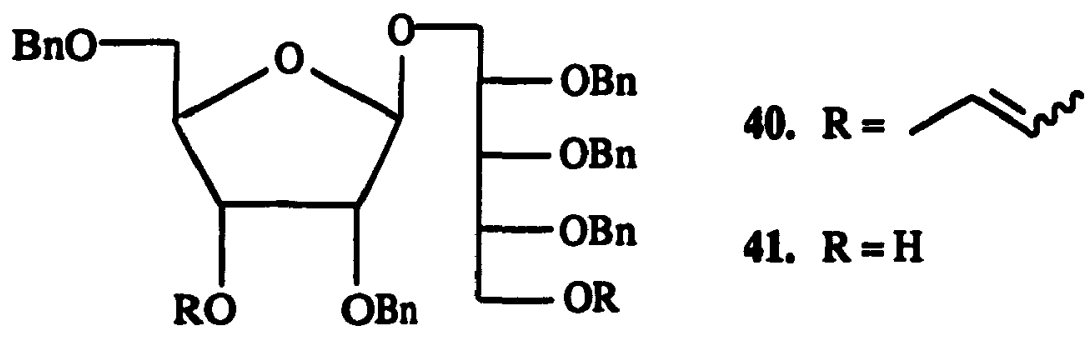

In a recent publication, Hutchins ${ }^{41}$ reported that ( $\pi$-allyl)palladium complexes could be reduced by lithium triethylborohydride to give the corresponding alkene in good yields. Thus, when a solution of the di-allyl ether 38 in dioxane was refluxed in the presence of catalytic $(0.02 \mathrm{eq})$ tetrakis(triphenylphosphine)palladium(0) and three equivalents of lithium triethylborohydride for less than one hour the desired diol $\mathbf{4 1}$ was obtained cleanly and in excellent yields (80-90\%). The ${ }^{1} \mathrm{H}$ NMR of the compound obtained was identical to that of the diol obtained by Corey's deallylation procedure. The primary alcohol was then selectively masked by reaction with monomethoxytrityl chloride, pyridine and DMAP giving the trityl ether $\mathbf{4 2}$.

\subsection{Methods for forming phosphate linkages}

In order to form phosphate linkages between two substrates, one needs the reactive phosphorus derivative of one substrate which can be coupled to the other hydroxy 


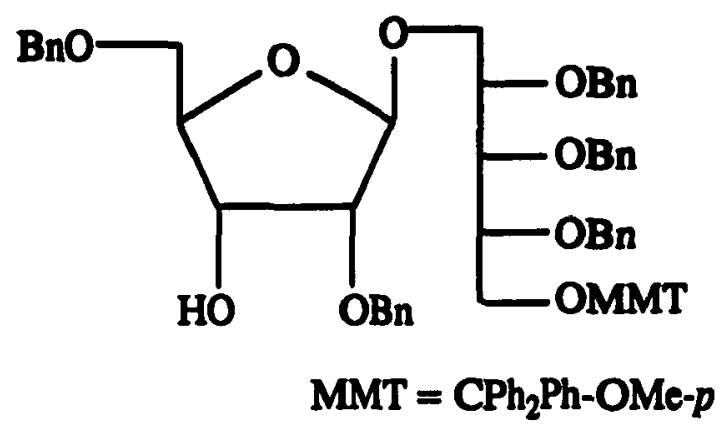

42

component. Many phosphorylating derivatives have been developed during the course of studies of oligonucleotide syntheses for both solution and solid-phase approaches. For example, there is the phosphodiester ${ }^{42}$ and the phosphotriester ${ }^{43}$ approach, the phosphite-triester ${ }^{44}$ approach and more recently the modified phosphite-triester approach ${ }^{45}$ also called the phosphoramidite approach. The latter is probably the method of choice nowadays. The intermediate phosphoramidite is stable and requires no special handling precautions, yet the phosphorous-nitrogen can be activated with a weak acid such as tetrazole. The protonated nitrogen derivative can then be displaced by the hydroxyl of the second component (scheme 7). In situ oxidation of the phosphite with aqueous iodine then affords the required phosphate.

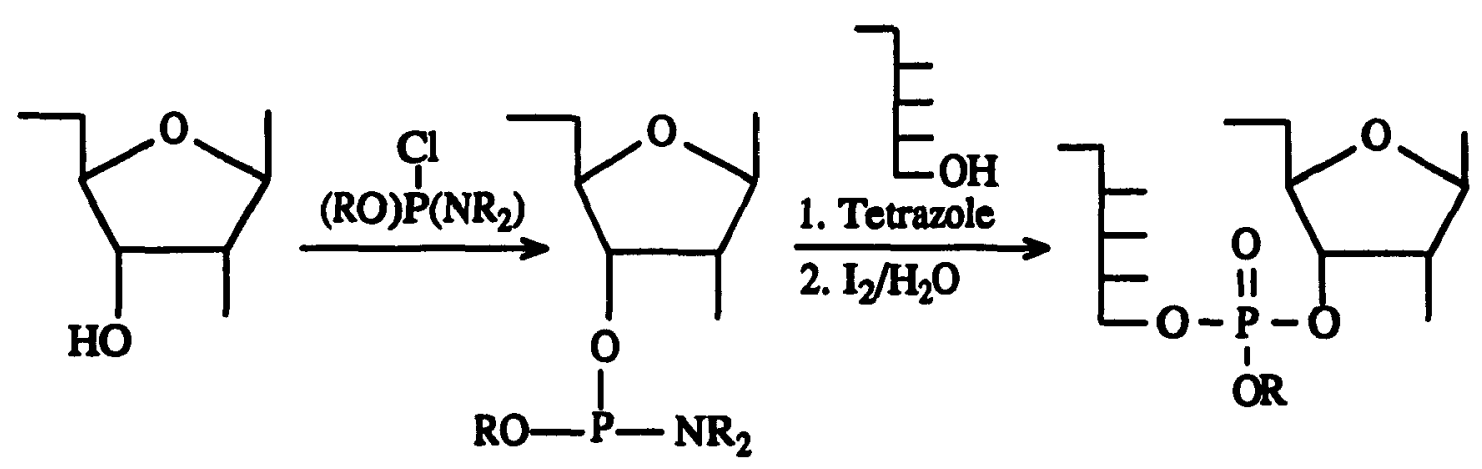

Scheme 7

Of the two commercially available phosphoramidites, we opted for the 2-cyanoethyl 
$N, N$-diisopropylchlorophosphoramidite rather than its methyl counterpart for several reasons, the major one being that the cyanoethyl protecting group can be easily cleaved with concentrated ammonia whereas deprotection of the methyl derivative requires refluxing tert-butylamine. Also, if the need to synthesize large fragments of the polysaccharide by a solid-phase approach were to arise, the cyanoethyl protected phosphate would be more advantageous as the ammonia-decyanoethylation ${ }^{46}$ sequence would also cleave the ester linkage between the support and the compound thereby reducing the number of deprotection steps. The other reason was purely speculative; in the synthesis of a tetramer of the PRP polysaccharide using $N, N$-diisopropylmethylchlorophosnhoramidite as the phosphorylating agent ${ }^{30}$, Wang observed that his product appeared as numerous spots on TLC. This inhomogeneity is simply due to the fact that the phosphate moiety is chiral and with three phosphates in his molecule there could be in theory eight diastereomers; purification was, as a result, difficult. We reasoned that, perhaps with a differently protected phosphate, the products would be chromatographically more homogeneous.

\subsection{Synthesis of a dimeric fragment of PRP}

The alcohol 42 was phosphorylated using 2-cyanoethyl $N, N$ diisopropylchlorophosphoramidite and diisopropylethylamine in $\mathrm{THF}^{45}$ to give the cyanoethyl phosphoramidite $\mathbf{4 3}$ in excellent yields. As expected the product survived an aqueous workup and silica gel chromatography. The ${ }^{31} \mathrm{P}$ NMR showed the expected signal at $149.8 \mathrm{ppm}$. Since 43 was to be coupled to the 5-hydroxy function of another ribose-ribitol component, the 3' hydroxyl had to be blocked with a protecting group which could be removed independently of the fragile phosphotriester linkage and the trityl ether. The levulinate ester possesses all these characteristics. Alcohol $\mathbf{4 2}$ was converted to its levulinate ester 44 by reaction with levulinic acid, DMAP and the coupling agent DCC ${ }^{47}$. Both the starting material and the levulinate ester had the same Rf value on TLC but the 
identity of the product could be easily confirmed by NMR. The ${ }^{1}$ H NMR was also radically different from the other ribofuranosyl-ribitol derivatives; for example the anomeric proton appeared as a doublet with a coupling of $2 \mathrm{~Hz}$ whereas in all previous intermediates the anomeric proton was invariably a sharp singlet. Furthermore, all the signals of the ribosyl portions were well resolved and could be assigned to their respective protons whereas in the other intermediates, the ${ }^{1} \mathrm{H}$ NMR were not as characteristic. The key intermediate 45 was then obtained by detritylation of levulinate ester 44 using a $5 \%$ solution of trichloroacetic acid (TCA) in methylene chloride. The ${ }^{1} \mathrm{H}$ NMR of this compound also followed the same trend.

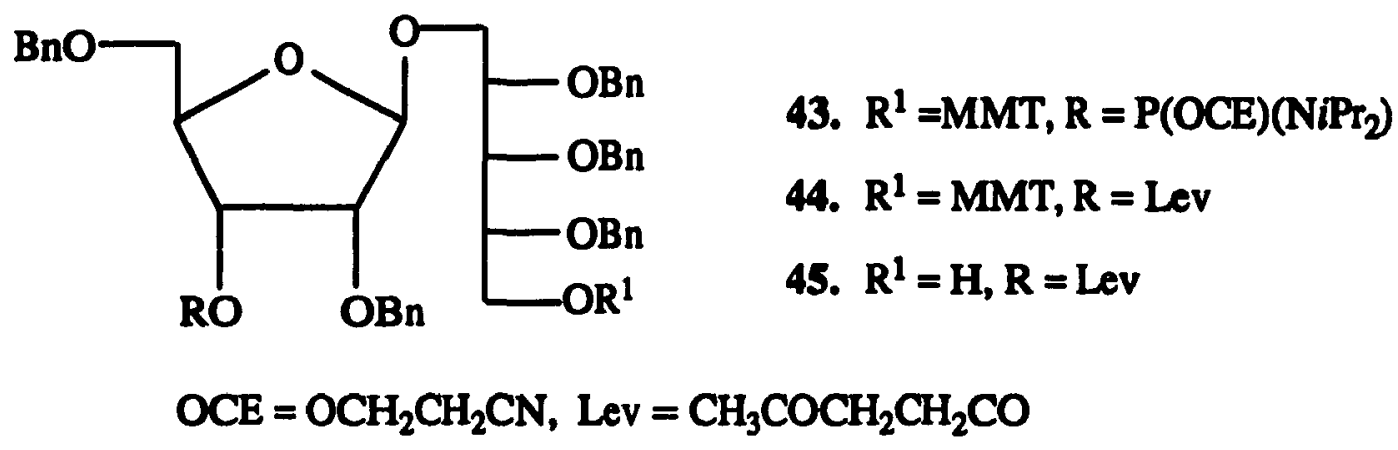

The coupling of 43 to 45 was then achieved by adding alcohol 45 to a solution of the phosphoramidite $\mathbf{4 3}$ and an excess of freshly sublimed tetrazole in dry acetonitrile ${ }^{48}$. The resulting phosphite was then oxidised with aqueous iodine to give the tetrasaccharide 46 in 85-90\% yield. Its ${ }^{31}$ P NMR was typical of chiral phosphate triesters. It showed two equal signals at -1.27 and $-1.65 \mathrm{ppm}$ indicating that both diastereomers of the phosphate were present. This reaction was readily scaled up and the dimer, which would eventually be used as an important building block, could be obtained in multigram quantities.

We also attempted to determine if the tetrazole activated phosphoramidite would show any selectivity between a primary and a secondary alcohol. If such a reaction proved 


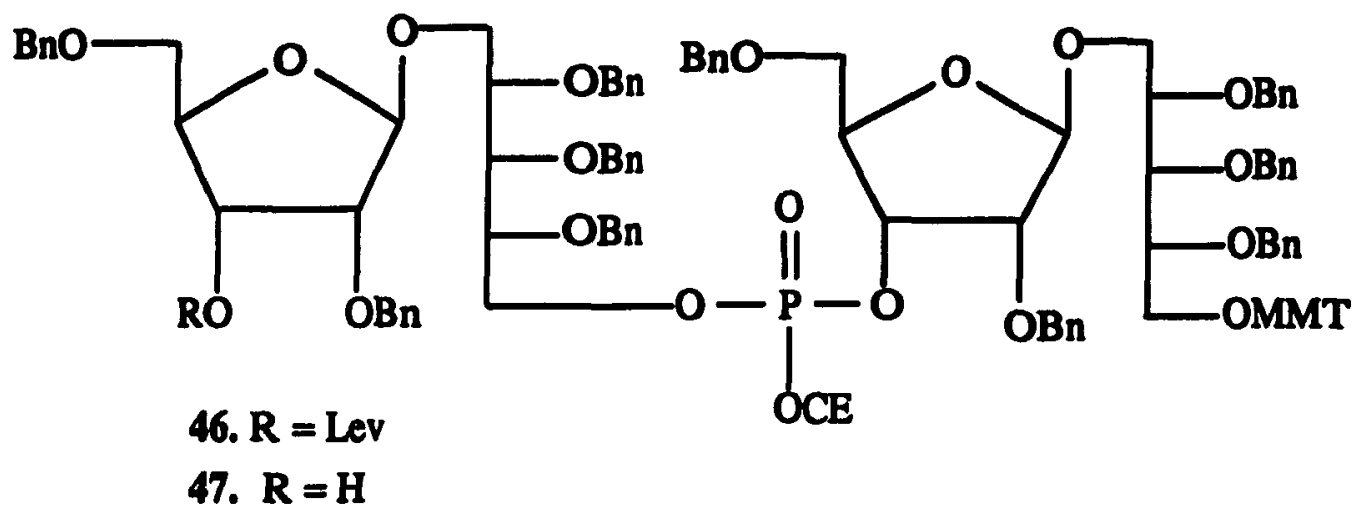

to be feasible, one could envisage the coupling between diol 41 and phosphoramidite 43 to give alcohol 47 thus rendering the levulinate protection-deprotection sequence superfluous. The diol 41 was therefore added to an ice cold solution of one equivalent of phosphoramidite 43 and excess tetrazole in acetonitrile. The reaction was carefully monitored by TLC. After $10 \mathrm{~h}$, TLC revealed the presence of two new spots with similar Rf

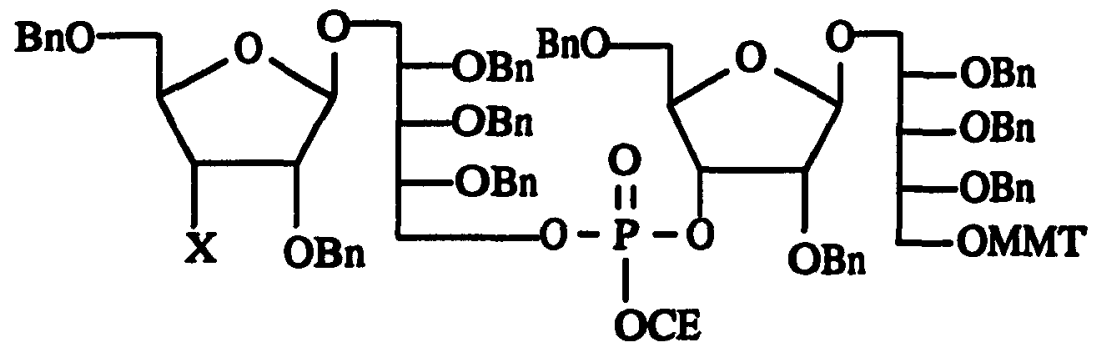

47. $\mathrm{X}=\mathrm{OH}$

48. $X=$

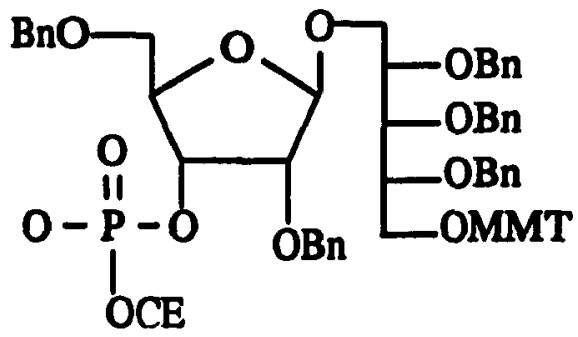

values which were separated by preparative TLC to yield two compounds in approximately 1:1 ratio. The less polar spot showed the expected ${ }^{31}$ P NMR $(-1.13,-1.49 \mathrm{ppm})$ and the ${ }^{1} \mathrm{H}$ 
NMR had a doublet at $3.5 \mathrm{ppm}$ which disappeared upon treatment with $\mathrm{D}_{2} \mathrm{O}$. Furthermore, the ${ }^{1} \mathrm{H}$ NMR was superimposable on that of alcohol 47 obtained by delevulination of dimer 46. This compound was therefore most likely to be the desired alcohol 47. The other compound had four peaks in the ${ }^{31}$ P NMR and the ${ }^{1} \mathrm{H}$ NMR was featureless. On the basis of its ${ }^{31}$ P NMR, we reasoned that there were probably two phosphate groups therefore the compound must have structure 48. The coupling reaction therefore showed no selectivity.

\subsection{Deprotection and characterization of the dimer}

In order to characterise this important intermediate and test our deprotection sequence, it was fully deblocked as follows. The levulinate ester was removed independently from the other masking groups by the action of $0.5 \mathrm{M}$ hydrazine in pyridine-acetic acid buffe ${ }^{47}$ to give alcohol 47. ${ }^{31} \mathrm{P}$ NMR confirmed that the phosphate-triester group was intact. The trityl group was removed next using a solution of TCA in methylene chloride. Treatment of this diol with concentrated ammonium hydroxide effected decyanoethylation efficiently; the reaction was over almost instantaneously. Hydrogenolysis of the benzyl groups in the presence of $10 \% \mathrm{Pd} / \mathrm{C}$ at 30 psi yielded the tetrasaccharide as the ammonium phosphate salt. The compound was then passed through a $\mathrm{Na}^{+}$form ion exchange column. Lyophilization gave the fully deprotected tetrasaccharide as sodium salt 49 . The ${ }^{31} \mathrm{P},{ }^{13} \mathrm{C},{ }^{1} \mathrm{H}$ NMR was identical to the reported data $^{30}$. Also, the high resolution FAB mass spectrum was well within acceptable limits.

\subsection{Design of the spacer.}

The poly-ribosyl-ribitol-phosphate or fragments of it can be an effective immunogen when attached to a carrier molecule. A spacer must comprise of a bifunctional molecule, preferally with a hydroxyl which can be attached to the oligosaccharide via a phosphate bond. The other functionality must be able to react with the protein (carboxylic acid or 


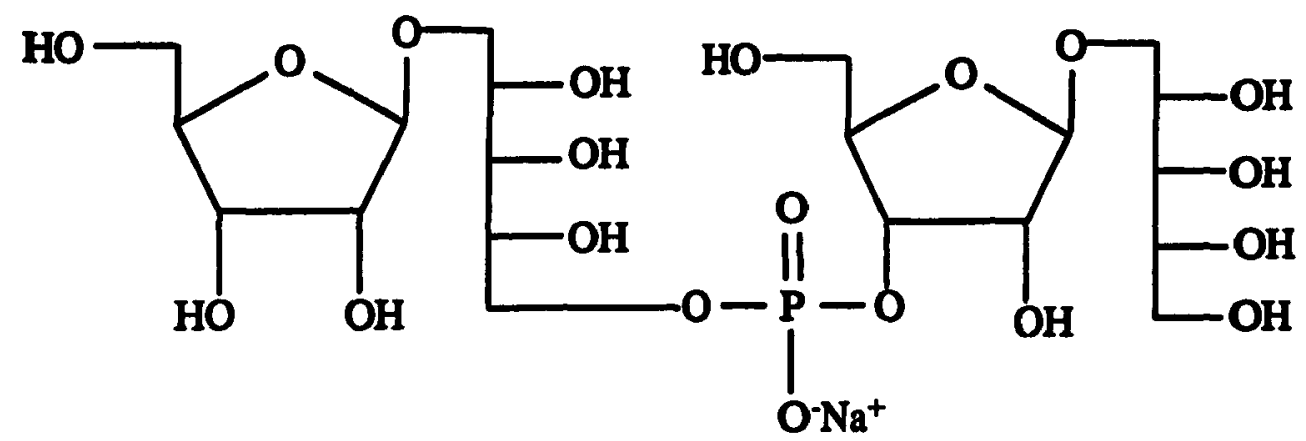

49

amino groups). Potential candidates are aldehydes (reductive amination), amines (amide formation), thiols (oxidative disulfide formation) and activated carboxyl groups which can react with the amino funtionalities of the protein. Various spacers have been used to link the synthetic oligosaccharide to the carrier. Garegg reported the use of a p-aminophenyl derivative 11. However, no biological results have so far been described for this compound. A trimer of PRP carrying a glycinamide spacer $\left(-\mathrm{O}-\left(\mathrm{CH}_{2}\right)_{3} \mathrm{NHCOCH}_{2} \mathrm{NH}_{2}\right) 15$ was successfully linked (presumably with carbodiimide) to a tetanus toxoid molecule and the conjugate was reported to elicit a very promising immune response. As mentioned earlier, the use of any spacer unit brings with it the risk of eliciting an immune response in a host against the spacer. This possibility thus argues against using any spacer at all. Therefore it was felt that the ideal spacer would be one derived from a representative part of the molecule. Such a spacer will therefore have the structural feature of $\mathbf{5 0}$ or $\mathbf{5 1}$.

The spacer 51 where $X$ is an aldehyde has already been described by Wang $^{30}$. The aldehydic functionality is, we believe, ideal as the linking step will be very specific. Aldehydes will only react with the amino groups of the proteins under reductive amination conditions. Other functionalities such as the amino group requires carbodiimide to effect linkage. Under these conditions significant cross linking in the protein will also take place. Thiols are also incompatible with catalytic hydrogenolysis of the benzyl ethers. The spacer 


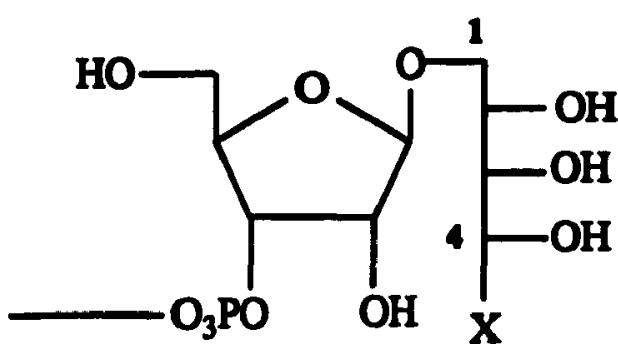

50

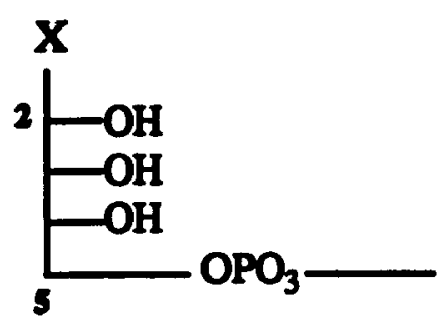

51

$$
\mathrm{X}=\mathrm{CHO}, \mathrm{CH}_{2} \mathrm{NH}_{2}, \mathrm{CH}_{2} \mathrm{SH}, \mathrm{CH}_{2} \mathrm{X}, \mathrm{COY}
$$

with structure $51(\mathrm{X}=\mathrm{CHO})$ is also more easily accessible as it can in principle be directly derived from D-ribose, whereas spacer $50(\mathrm{X}=\mathrm{CHO})$ can be derived in a simple manner from the costly L-ribose (D-ribose $\$ 0.35 / \mathrm{g}$, L-ribose $\$ 60 / \mathrm{g}$ ). Therefore, preparation of spacer $\mathbf{5 0}$ is not very practical.

In the design of the spacer, we also strove to maintain our initial consideration for keeping all the unneeded hydroxy groups blocked with hydrogenolyzable groups so as to diminish the number of deprotection steps. Having decided to use a ribose spacer for reasons mentioned before, we opted for the spacer described by Wang, i.e. benzyl-2,3-O-benzylidene- $\beta$-D-ribofuranoside 52. Again the benzyl groups can be hydrogenolyzed thus freeing the aldose which can then be attached to the carrier protein using the appropriate reagent.

\subsection{Synthesis of the spacer.}

The spacer was synthesized by stirring a DMF solution of ribose, benzyl alcohol and benza: ${ }^{2}$ ehyde dimethyl acetal under vacuum in the presence of acid. The desired compound was obtained in $\mathbf{4 0 \%}$ yield as a 1:1 mixture of exo and endo isomers of the benzylidene moiety. Phosphorylation with the cyanoethyl phosphoramidite in the presence 
of diisopropylethylamine gave the crucial intermediate 53. The ${ }^{31 P}$ NMR showed the expected signal (139.5, $143.4 \mathrm{ppm})$.

The synthesis of oligosaccharides of PRP involve a large number of repetitive steps and is therefore well suited for a solid-phase approach, especially for large oligomers (e.g. > 10 units). We therefore decided to devise a strategy which would prove useful should the

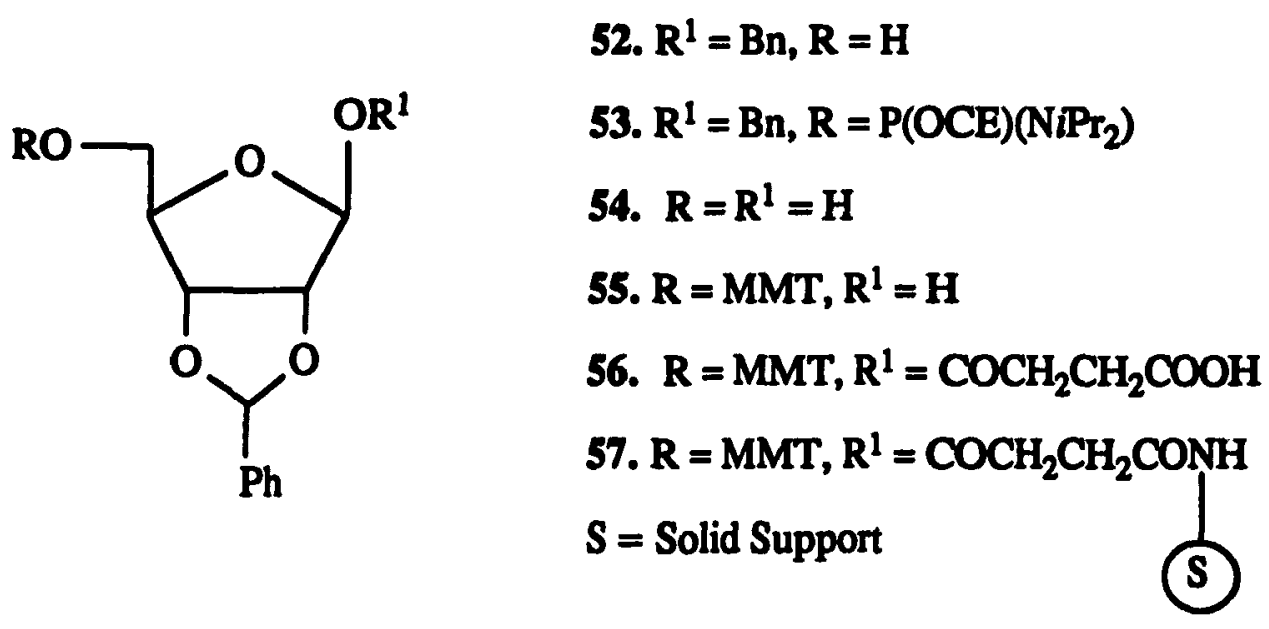

solid-phase synthesis of oligosaccharides of PRP attached to the spacer be necessary. Since the spacer is to be linked to the 3' position PRP oligomer, we envisaged the initial linkage of the spacer to the support followed by addition of units of PRP. Our proposed scheme for the modified spacer starts with 2,3-O-benzylidene D-ribofuranoside 54. The 5-hydroxyl can be monomethoxytritylated to give 55 and finally the succinate monoester 56 of the anomeric alcohol is prepared (succinic anhydride/pyridine/DMAP). The free acid portion can be activated by conversion to the corresponding labile pentachlorophenol ester. Reaction of the alkyl amine termini of the solid support with the activated ester will thus attach the spacer to the support by forming amide 57. Detritylation then liberates the primary alcohol and the addition of a phosphoramidite (e.g. 43) will give the monomer-spacer. The last sequence can be repeated until the desired chain length has been 
obtained ${ }^{49}$. The final product can then be cleaved from the support by treatment with ammonium hydroxide.

\subsection{Strategies towards building oligomers of PRP attached to the spacer}

With the apppropriate reagents in hand, the synthesis of larger fragments and their deprotection could be attempted. Since the relation between immunogenic activity and the number of units of the polysaccharide has not yet been established, we decided to construct five oligomers of the Hib polysaccharide by a blockwise approach. All of them will be carrying the D-ribose spacer at the 3' site. Our strategy was to couple the spacer $\mathbf{5 3}$ to the previously described trityl alcohol 42 (page 29) and delevulinated dimer 47 (page 32) to yield the monomer-spacer and the dimer-spacer respectively. Hydrolysis of the monomethoxytrityl group of the terminal ribitol will yield an alcohol which can react with the phosphoramidite moiety of another PRP unit, thus allowing chain elongation. Since a blockwise approach is more efficient than a stepwise approach, we decided to use the phosphoramidite of tetrasaccharide (dimer) 47 as the key building block. Thus, the coupling of this phosphoramidite with the monomer-spacer and dimer-spacer will give the trimer-spacer and the tetramer-spacer respectively. Similarly, addition of the tetrasaccharide to the trimer-spacer will afford the pentamer-spacer.

Thus, the alcohol 47 was converted to the phosphoramidite 58 using the standard procedure. The synthesis of this intermediate was not without problems; purification of the phosphoramidites were usually performed by chromatography on silica gel and eluting with an appropriate solvent mixture containing $1-2 \%$ vol/vol triethylamine (TEA). When this purification procedure was attempted on 58, decyanoethylation of the central phosphotriester occured thus reducing the yields drastically. However, the use of dry solvents and a $0.5 \%$ TEA solution and a rapid flow rate brought the yields to satisfactory 
levels (75-90 \%). The structure of this phosphoramidite was confirmed by ${ }^{31 P}$ NMR; two peaks at -1.77 and $-1.35 \mathrm{ppm}$ could be attributed to the phosphate and downfield signals at 149.8 and $150.0 \mathrm{ppm}$ were attributed to the phosphoramidite moiety.

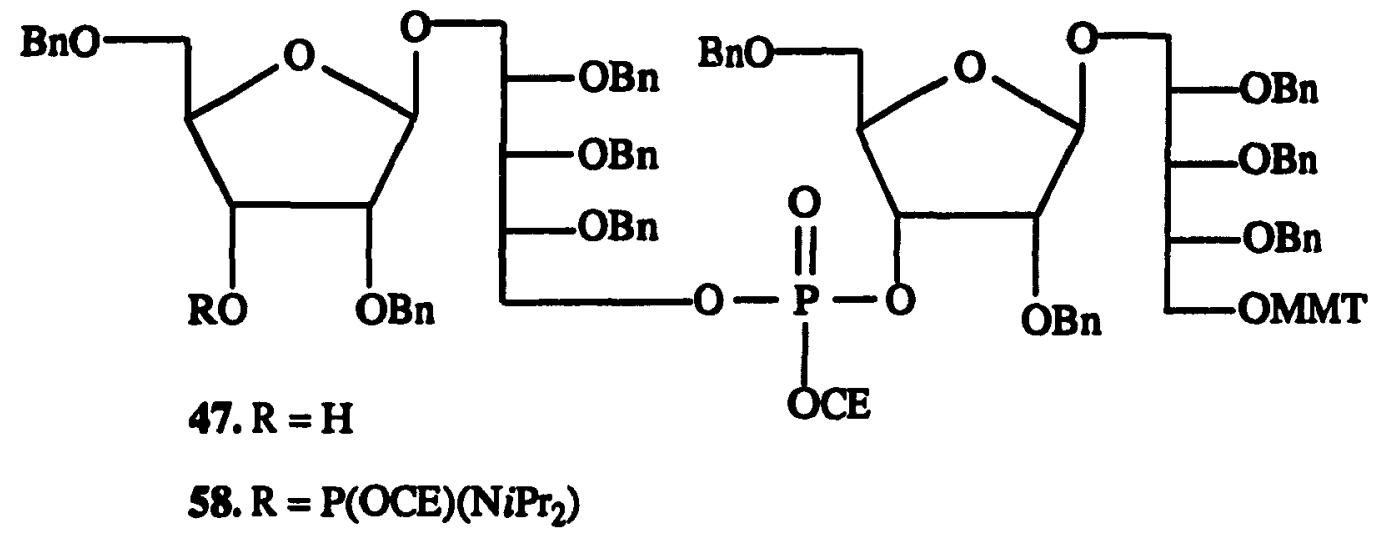

\subsection{Synthesis of the monomer-spacer}

The building of the oligomers could then be attempted. Coupling of the phosphorylated spacer 53 and the alcohol 42 (page 29) gave the monomer-spacer 59 in excellent yields. The TLC showed three new overlapping spots which could be separated with some difficulty. The ${ }^{31}$ P NMR of each of these compounds showed a sharp peak in the $-2 \mathrm{ppm}$ region indicating that coupling has indeed taken place. Due to the presence of exo and endo isomers in the spacer and the chirality of the phosphate there could be a possibility of four diastereomers. As a result the ${ }^{31} \mathrm{P}$ NMR was more complex.

\subsection{Deprotection of the monomer-spacer 59}

Nevertheless, we were confident that we had the monomer-spacer 59 in hand and it was then decided to fully deprotect the trisaccharide in order to characterize it. The trityl ether was hydrolyzed and treatment of the product with concentrated ammonium hydroxide hydrolysed the cyanoethyl protecting group of the phosphate. Hydrogenolysis at $30 \mathrm{psi}$ in the presence of $10 \% \mathrm{Pd} / \mathrm{C}$ gave a product which had a ${ }^{31} \mathrm{P}$ NMR signal at $0.73 \mathrm{ppm}$ as 


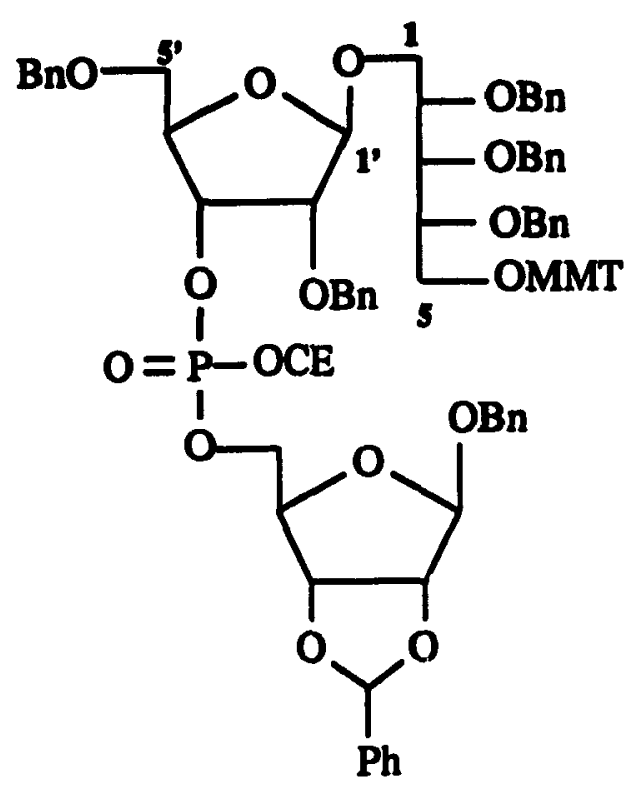

59

expected and a small peak at $0.27 \mathrm{ppm}$. However, both the anomeric patterns in the ${ }^{1} \mathrm{H}$ and ${ }^{13} \mathrm{C}$ NMR spectra were totally unexpected. The ${ }^{1} \mathrm{H}$ NMR indicated the presence of only a sharp singlet at $4.87 \mathrm{ppm}$ whereas ${ }^{13} \mathrm{C} \mathrm{NMR}$ had a single peak at $109.5 \mathrm{ppm}$. It was very unlikely that the anomeric $\mathrm{H}$ or $\mathrm{C}$ signal for an alkyl ribofuranoside would overlap on the signal of a free ribose. Furthermore, the $3^{\prime}$ proton appeared at a characteristic region ( $\sim 4.4$ ppm) and the integration indicated that the anomeric singlet comprised of only one proton. Also, Bock has reported that the ${ }^{13} \mathrm{C}$ NMR of free ribose had signals at 97 and $101 \mathrm{ppm}^{50}$ for the $\alpha$ and $\beta$ - anomer respectively and in our case, these regions were devoid of any signals.

The FAB mass spectra provided a clue to the answer; a peak at $521\left(\mathrm{M}+\mathrm{H}^{+}\right)$instead of 519 indicated that the aldose had unfortunately been reduced to the ribitol 60 . The overreduction was totally unexpected. According to Rylander ${ }^{51}$, catalytic reduction of aldehyde to the alcohol using palladium metal catalyst is inefficient, for is tance, he reported that pressures of the order of $300-4500$ psi are required. Initially, we reasoned that 
perhaps the activated nature of the hemiacetal species contributed to its ease of reduction. However, Cadotte et al ${ }^{52}$ reported that a hemiacetal was stable to catalytic reduction using palladium on caithon at 1200 psi. At ambient pressures and with careful monitoring of the hydrogen consumption, wh could obtain some desired compound but the process was slow and monitoring the uptake of hydrogen was very tedious. There was also the danger that with larger oligomers (i.e more benzyl groups), the hydrogenolysis might not go to completion. Also, in all the trials, FAB mass spectrometry indicated the presence of some overreduced products.

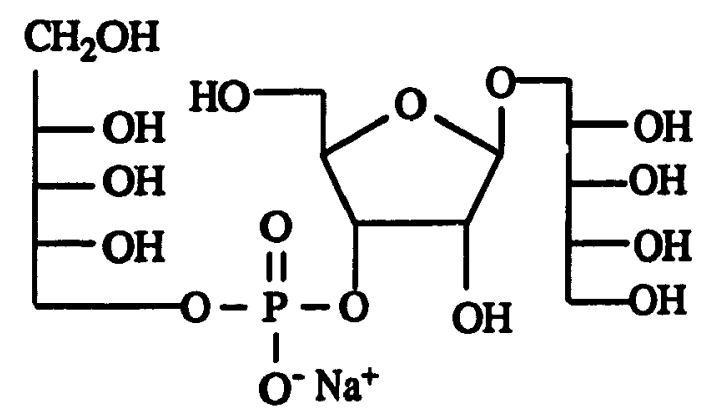

60

It was therefore apparent that a protecting group which could be removed after hydrogenolysis of the benzyl groups was required for the anomeric center of the spacer. The following criteria must therefore be met: this protecting group must withstand catalytic reduction, mildly acidic conditions (TCA) and basic media $\left(\mathrm{NH}_{4} \mathrm{OH}\right)$. Aisc, its deprotection should preferably not require highly acidic medium because of the phosphodiester linkages. We opted for the tert-butyldimethylsilyl (TBDMS) ${ }^{53}$ group as it would probably fulfil all the requirements mentioned.

\subsection{Synthesis of the silylated spacer}

The desired silylated spacer was then prepared as follows; reaction of ribose with benzaldehyde in the presence of acid and anhydrous copper sulfate gave the 
2,3-O-benzylidene-D-ribofuranoside 54 which was then monomethoxytritylated to give 55 . Silylation of the anomeric alcohol with TBDMSCl and imidazole afforded compound 61 as a mixture of anomers $(\alpha / \beta=1: 3.5)$. Removal of the trityl group was best achieved with anhydrous TCA in methylene chloride; use of commercial TCA was often accompanied with partial desilylation as well. At this stage, the anomeric mixture was separated by chromatography and only the $\beta$-anomer was used in the subsequent reactions. Phosphorylation of alcohol 62 using standard conditions provided us with the key intermediate 63. (31P NMR 148.6, $148.8 \mathrm{ppm}$ ). This sequence also provided us with an unexpected bonus. The benzylidene acetal existed as one single isomer (presumably the more stable exo isomer); ${ }^{1} \mathrm{H}$ NMR showed only one singlet at $5.5 \mathrm{ppm}$ for the benzylidene acetal proton. We were therefore assured of simpler and more easily interpretable NMR spectra (at least for the smaller oligomers).

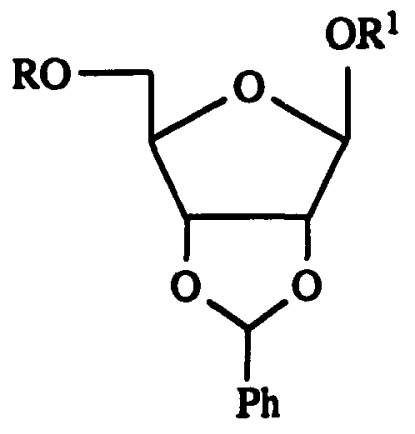
54. $R=R^{1}=H$
55. $R:=M M T, R^{1}=H$
61. $R=M M T, R^{1}=T B D M S$
62. $R=H, R^{1}=$ TBDMS
63. $\mathrm{R}=\mathrm{P}(\mathrm{OCE})\left(\mathrm{NiPr}_{2}\right)$, $\mathrm{R}^{1}=\mathrm{TBDMS}$

Should the need for the construction of large fragments on a solid support arise, the silylated spacer may also be adapted. The same sequence described above can be used with the exception that the p-methoxybenzylidene acetal is used to protect the 2, 3 hydroxyls. This acetal can be reduced by a variety of methods (e.g. sodium cyanoborohydride/trimethyl silyl chloride ${ }^{54}$ or DIBAL- ${ }^{55}$ ) to give a $\mathrm{p}$-methoxy benzyl ether and the free hydroxyl. The free hydroxyl will thus allow the linkage of the spacer to the solid support by the method decribed earlier. Although several researchers $54,55,56,57$ 
have obtained excellent regioselectivities in the reduction of $p$-methoxybenzylidene acetals by using different combinations of reducing agents and Lewis acids, we have so far failed to selectively cleave the 2,3-0-acetal of model compounds. We believe that it is not likely that the mixture of the 2 or 3 linked spacer will be of any consequence in the construction of larger oligomers.

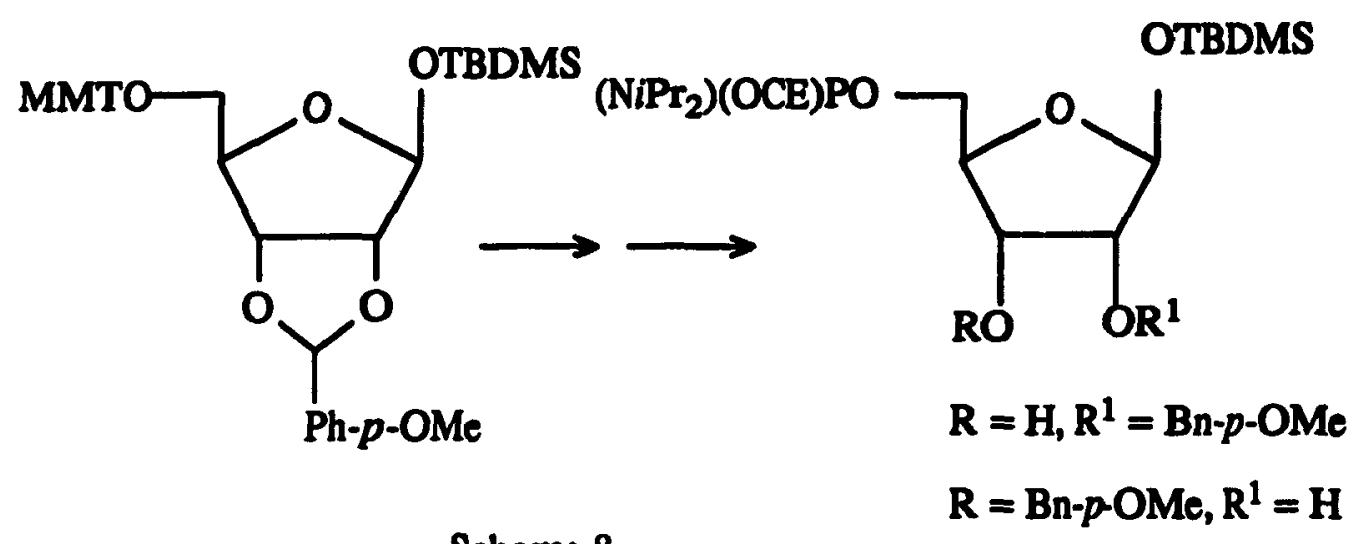

Scheme 8

\subsection{Synthesis and deprotection of monomer-spacer}

Coupling of phosphoramidite 63 with alcohol 43 in the presence of excess tetrazole (7-10 eq.) and subsequent oxidation yielded the monomer-spacer $64(n=1)$ in excellent yields (90\%). It was also a pleasant surprise to find that the TLC was well resolved and the product also appeared as a homogeneous spot. Spectroscopic analysis was, as expected, much easier; ${ }^{31} \mathrm{P}$ NMR showed two peaks at -2.0 and $-2.1 \mathrm{ppm}$ for the two diastereomers. The identity of the compound was then confirmed by characterisation of its fully deprotected analog. We also wanted to test the feasibility of the deprotection sequence. After detritylation with TCA under anhydrous conditions, the phosphate was deprotected using ammonium hydroxide. The resulting ammonium phosphate derivative was purified by preparative TLC. Debenzylation at 40 psi afforded the silylated trisaccharide $66(n=1)$ which was purified by $\mathrm{Na}^{+}$ion-exchange chromatography. After lyophilization, a white 


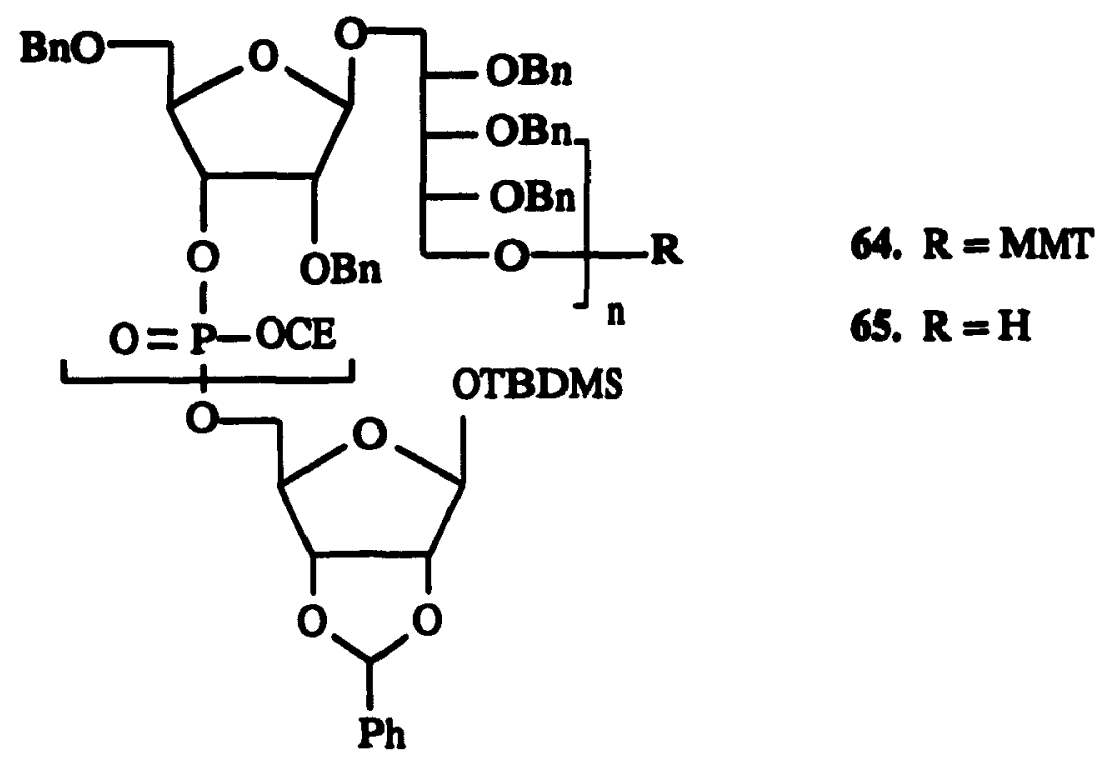

powder was obtained. The characteristic signals in the ${ }^{1} \mathrm{H}$ NMR were the two methyl singlets at $0 \mathrm{ppm}$, the tert-butyl singlet at $0.7 \mathrm{ppm}$, the $\mathrm{H}-3^{\prime}$ multiplet and the two anomeric singlets at 4.8 and $5.1 \mathrm{ppm}$, all of them integrating in the correct proportions. The ${ }^{13} \mathrm{C}$ NMR was also very instructive; fifteen sugar carbons could be accounted for of which a number showed P-C coupling. ${ }^{31} \mathrm{P}$ NMR showed one peak at $0.16 \mathrm{ppm}$ and the FAB mass spectra confirmed the presence of a compound of mass 632 .

Encouraged by these results, we then diveried our efforts towards finding a suitable desilylating agent. TBDMS ethers have been removed by a variety of reagents, the most common ones being acids and naked fluoride ions. Both are not very practical for our use; acids might destroy the fragile phosphodiester linkage and naked fluoride ions such as tetra$n$-butylammonium fluoride requires the use of aprotic solvents such as THF or DMF. Our compound and especially the larger oligomers are probably more water soluble and also the removal of the polar and higher boiling solvents such as DMF and DMSO is impractical. We then decided to evaluate the possibility of using potassium hydrogen fluoride $\left(\mathrm{KHF}_{2}\right)$ as 


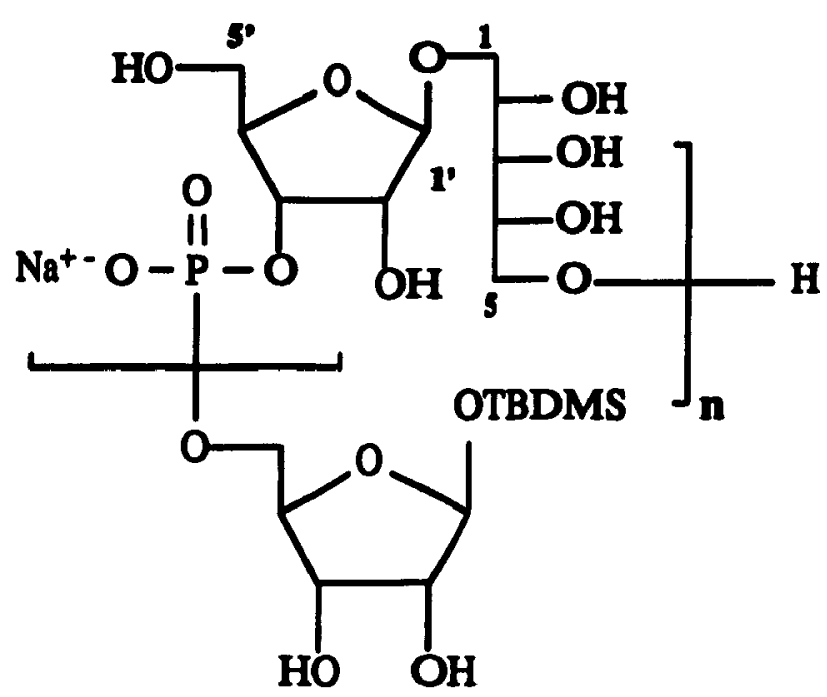

66

a desilylating agent on a model compound. When a solution of TBDMS ribofuranoside 67 (obtained from hydrogenolysis of 62 ) in methanol/water was treated with $\mathbf{K H F}_{2}$, desilylation was prompt and complete. An aqueous solution of $\mathbf{X H F}_{2}$ was slightly acidic (pH 3-4), and fearing that the acidity might be deleterious to the phosphodiester linkages, the fluoride solution was buffered to $\mathrm{pH} 6$ with pyridine and this system was found to work equally well on our model compound.

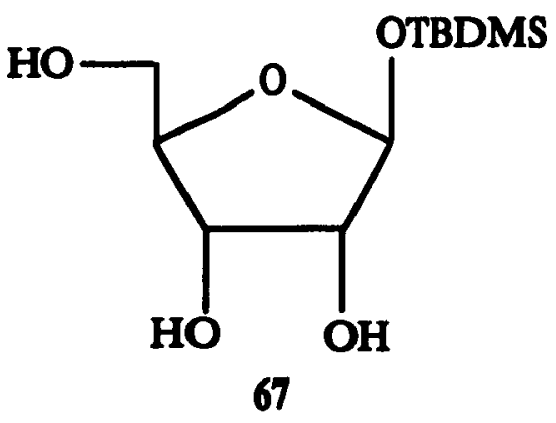

Therefore, the silylated monomer-spacer $66(n=1)$ was treated with a buffered solution of $\mathbf{K H F}_{2}$ and allowed to stir overnight in a polypropylene vessel. A Benedict's test at this point indicated the presence of a reducing sugar. The monomer was then purified by washing the solution with organic solvents. Subsequent passage through a $\mathrm{Na}^{+}$ion 
exchange column, eluting with water, and lyophilization yielded the desired compound as a white powder. The ${ }^{1} \mathrm{H}$ NMR showed complete abseric of silyl signals. Furthermore, the anomeric region now contained three signals one of which $(4.87 \mathrm{ppm})$ could be ascribed to the riboside proton (H-1'). The two other signals which appeared as doublets could be assigned on the basis of their coupling constants to the $\beta$ and $\alpha$ anomeric proton of the ribose spacer. ${ }^{13} \mathrm{C}$ NMR added proof to our interpretation. A signal at 109.5 was assigned to $C-1^{\prime}$, and the $\beta$ and $\alpha$-anomer of ribose showed signals at 99.2 and $103.9 \mathrm{ppm}$ respectively. The last two signals were well in agreement with the findings of Bock (101 and 97 ppm respectively). ${ }^{50}$ As expected, the ${ }^{31}$ P NMR showed a single peak at $0.2 \mathrm{ppm}$. And finally, high resolution FAB mass spectroscopy recorded an exact mass of 519.10909 $\left(\mathrm{M}+\mathrm{H}^{+}\right)$whereas the calculated value was 519.10616.

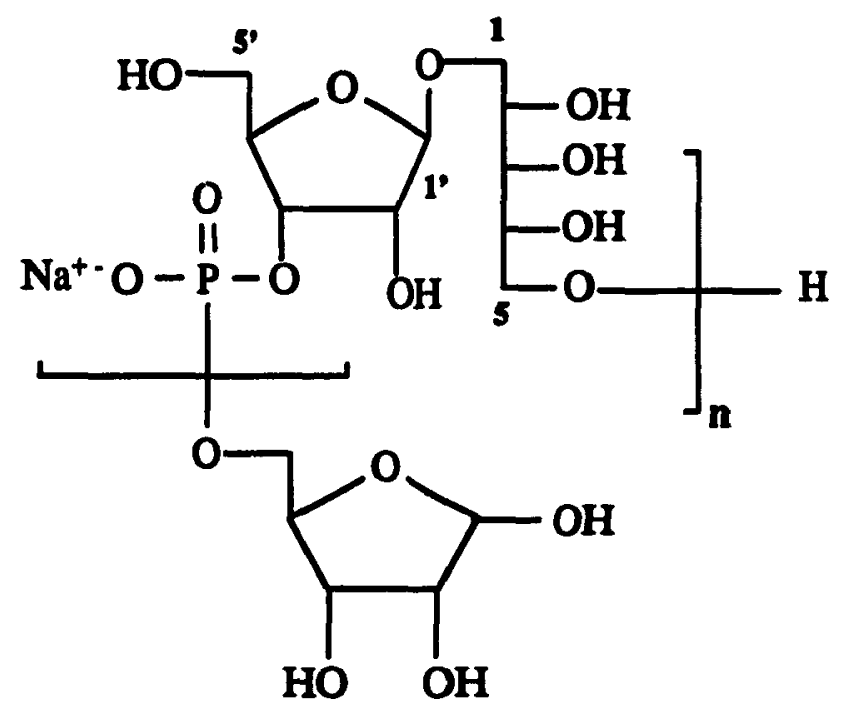

68

\subsection{Synthesis of oligomers of PRP attached to the spacer}

Feeling that our goal (oligomers $n=1-5$ ) was now within reach, we embarked on the constuction of larger fragments of the Hib polysaccharide. The monomer-spacer $64(n=1)$ was then detritylated using anhydrous trichloroacetic acid and addition of the resulting 
alcohol $65(n=1)$ to the phosphoramidite 58 and tetrazole gave good yields of the trimer-spacer $64(n=3)$. The ${ }^{31} \mathrm{P}$ NMR were as expected not as characteristic as for the monomer-spacer due to the possibility of having all eight diastereomers. Similarly, the pentamer-spacer $64(n=5)$ was obtained by reaction of phosphoramidite 58 with detritylated trimer-spacer $65(n=3)$. The ${ }^{31} P$ NMR was very complex due to the possible presence of thirty two diastereomers. Nevertheless, we felt that the reactions have proceeded to completion as desired. Our reaction conditions made use of a large excess of tetrazole (7-10 eq) and as much phosphoramidite 58 as we could afford (1.3-1.8 eq) in order to drive the reaction to completion. The coupling reactions were also allowed to proceed for $72 \mathrm{~h}$ instead of the usual $24 \mathrm{~h}$. The TLC were also sufficiently resolved to indicate that the reaction was complete and little if any starting material remained.

The synthesis of the dimer-spacer could have been done by a stepwise fashion, i.e., spacer $+1+1$, but since we had some delevulinated dimer 47 available, we opted for the more efficient blockwise approach. Thus, the dimer-spacer $64(n=2)$ was prepared by reaction of the delevulinated dimer 47 and phosphorylated spacer 63. The ${ }^{31}$ P NMR pattern could easily be accounted for since it showed the requisite four equivalent peaks indicating that all four diastereomers were present. Finally, the tetramer-spacer $64(n=4)$ was obtained by treatment of the detritylated dimer-spacer $65(n=2)$ and the phosphoramidite 58. The yields obtained for the couplinmg reaction were in the 70-85\% range.

\subsection{Deprotection protocol}

The deprotection were then carried out as described for the monomer-spacer. The decyanoethylation step was allowed to proceed for 24 hours with the larger oligomers as shorter reaction times resulted, in one case, in incomplete reaction. All the compounds were characterized at the silyl-oligomer stage and also after full deprotection. We found 
that in onder to obtain final products which are as pure as possible the following sequence was ideal. After decyanoethylation, the product was purified by preparative TLC using mixtures of toluene and methanol and developing twice. The purified material could then be extracted from the silica gel scrapings with a 1:1 mixture of ethyl acetate and methanol. Hydrogenolysis then yielded the silylated oligomer. An aqueous solution of the compound was then washed twice with methylene chloride, once with ether and then finally with pentane. This washing sequence was found to remove all organic impurities. Passage through a $\mathrm{Na}^{+}$ion exchange column converted the phosphates to the sodium derivative. $A$ similar washing sequence was used after the desilylation step and no pyridine was detected in the ${ }^{1} \mathrm{H}$ NMR spectra. This procedure enabled us to obtain pure material as established by NMR $\left({ }^{1} \mathrm{H},{ }^{13} \mathrm{C},{ }^{31} \mathrm{P}\right)$.

It is interesting and perhaps not totally unexpected to note that in the ${ }^{1} \mathrm{H}$ and ${ }^{13} \mathrm{C}$ NMR for both the silylated polysaccharides and the fully deprotected ones, the anomeric protons or carbons of the ribosyl-ribitol moieties were identical. Similarly the ${ }^{31} \mathrm{P}$ signals for the the phosphate groups linking the ribosyl-ribitol groups were identical (for example, the phosphate connected to the ribose spacer appeared at 0.1-0.2 ppm whereas, all others appeared at $0.6-0.7 \mathrm{ppm}$. Only the ${ }^{13} \mathrm{C}$ NMR of the silylated dimer-spacer showed two barely resolved signals $(109.5,109.6 \mathrm{ppm})$ for the anomeric carbons of the ribosyl-ribitol moieties. The non anomeric pattern $\left({ }^{13} \mathrm{C}\right.$ and $\left.{ }^{1} \mathrm{H}\right)$ for all the oligomers was also very similar. Therefore, integration of the anomeric protons and carbons of the spacer and the ribosyl-ribitols provided us with an efficient means to establish the length of the chain. Similarly, the intensities of the spacer phosphate signals relative to the other phosphates confirmed the length of the oligosaccharide. FAB mass spectrometry analysis was unfortunitely feasible for only up to the silylated trimer-spacer and up to the fully deprotected dimer-spacer. Nevertheless, we are confident that the NMR analyses 
performed were sufficient to confirm the identities of the compounds reported.

\subsection{Biological evaluation of the haptens}

All the fully deprotected oligosaccharides $68(n=1-5)$ were then sent to Lederie Laboratories for preparation of the conjugates and biological evaluation. The carrier protein was the outer membrane protein of Haemophilus influenzae type b. The selection of this protein was governed by many factors; it was thought that a protein derived from the bacteria itself might avoid any immunological side-reactions due to the protein. Furthermore, several workers have already shown that these proteins can induce a protective response against the Hib bacteria ${ }^{8}$. This new immunogen may thus prove to be superior to other combinations of protein-hapten. Thus, the oligomers were treated with the protein in the presence of sodium cyanoborohydride. The $\mathrm{pH}$ was maintained at 6.7 throughout the reaction. The resulting conjugate was then administered to mice and the anti-Hib antibody response was monitored. However, only two out of ten mice showed a response. It was then decided to subject the complex to chemical degradation followed by protein analysis which involve the quantitative monitoring of the lysine residue by HPLC. The amount of this amino acid in the conjugate relative to that of the untreated protein thus provide a good approximation of the extent of conjugate formation. It was found that only the tetramer-spacer $68(n=4)$ showed barely detectable evidence of conjugate formation. These results were thus very promising as the amount of conjugate formed was virtually outside the detection limits of the HPLC and yet some of the animals gave a positive response.

At this point we decided to find the favorable conditions for the reductive amination of an amino group with a hemiacetal moiety. Accurate $\mathrm{pH}$ control in these reactions is important; the imminium ion formation which is rate determining is favored by low $\mathrm{pH}$ (Scheme 8). These conditions $(\mathrm{pH}<4)$ unfortunately also promote the reduction of the 


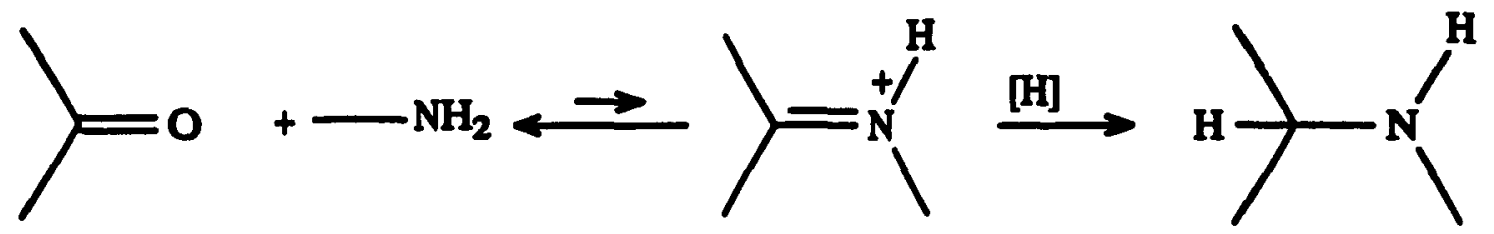

Scheme 8

carbonyl group ${ }^{58}$. Furthermore, the phosphodiester linkages might not survive high acid concentration. The reaction was therefore attempted at pHs ranging from 5 to 8 . Incidentally, Anderson prepared conjugates of acid-hydrolysed PRP with a protein by incubation for 18 days at $37^{\circ} \mathrm{C}$ and $\mathrm{pH}$ 8. We did not have sufficient quantities of the oligomers 68 for much experimentation, therefore we made use of a model compound, D-ribose. Thus an aqueous of solution of D-ribose and excess of benzylamine $(10 \mathrm{eq})$ was buffered to $\mathrm{pH} 5,6,7,8( \pm 0.2)$ and treated with sodium cyanoborohydride. The reaction was monitored by the Benedict's test for reducing sugars. It was found that the rate of reaction was $5 \approx 6>8>7$.

The formation of conjugates of haptens 68 with the above mentioned protein was once again attempted at $\mathrm{pH} 6$. This time the amino acid analysis indicated, as expected, excellent coupling of the oligosaccharide to the protein. Several test animals were then injected with the conjugate. This time it was found that all the animals including the controls gave inconsistent results. A viral infection of unrelated origin seemed to have afflicted all of the animals. The testing was thus temporarily suspended until the exact cause could be determined. 
Chapter 3

Attempted synthesis of fragments of the Escherichis coll K100 capoular polysaccharide.

The immune system recognition capability is not infaillible. Very often different immunogens or antigens can induce identical responses. The capsular polysaccharide of Escherichia coli K100 (E. coli) bacteria has been found to be antigenically and immunologically cross-reactive with that from Haemophilus influenzae type b bacteria. However, E. coli is not known to cause any invasive diseases in humans In fact, the bacteria sometimes occur naturally in the intestinal tracts of humans. It has also been postulated that the presence of these bacteria have contributed to the establishment of natural immunity against Hib diseases found in the majority of adults. Some authors have even suggested that feeding infants with live E. coli might be an efficient immunisation protocol. Unfortunately, the presence of larger than usual numbers of the E. coli bacteria in the faecal excretion of Hib patients have led researchers to believe that E. coli have somehow depressed the children's resistance against Hib.

In an effort to explain the cross reactivity the structure of the capsular polysaccharide of $\mathrm{E}$. coli has been determined by mass spectral studies 59 and more recently, by NMR ${ }^{60}$. Its structure is virtually identical to the Hib capsular polysaccharide. Both of them consist of D-ribofuranosylribitol moieties linked through phosphate bonds. The only difference lies in the position of the glycosidic linkage. The structure of the E. coli polysaccharide was found to be $\rightarrow 3)-\beta-D-R i b f-(1 \rightarrow 2)-D-r i b i t o l-5-\left(\mathrm{PO}_{4} \rightarrow 69(2-\mathrm{PRP})\right.$ as opposed to the $\rightarrow 3)-\beta-D-R i b f-(1 \rightarrow 1)-D-r i b i t o l-5-\left(\mathrm{PO}_{4} \rightarrow\right.$ for PRP. The similarity between the two capsular polysaccharide have led Schneerson and others to postulate that the E. coli polysaccharide, either by itself or as conjugates might be an alternative vaccine against Hib infections ${ }^{61}$. 


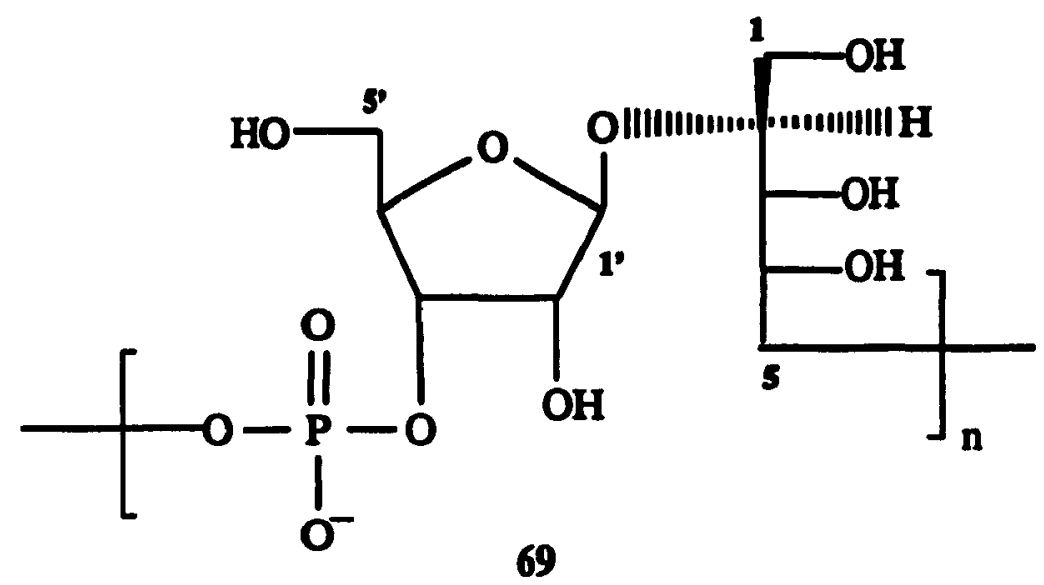

The similarity between the 2-PRP and PRP prompted us to seek an approach to synthesise the basic structure and oligomers of the polysaccharide attached to a ribose spacer. The synthesis of this compound can be viewed as the attack of 2-hydroxy group of a D-ribitol derivative to a a suitably activated ribose derivative. The latter can obviously be derived from the orthoester used in the synthesis of PRP. Since the two crucial hydroxyls are still at the 3 ' and the 5 positions, the same retrosynthetic approach as for PRP holds. The major difficulty in the synthesis of 2-PRP resides in obtaining the appropriate 2-hydroxy ribitol derivative. A similar problem has been encountered in the synthesis of Haemophilus influenzae type a polysacharide, in this case a 4-hydroxy D-ribitol moiety was involved. This intermediate was obtained by selective phase-transfer benzylation of the 1-hydroxyl of a 1, 4-di-hydroxy ribitol derivative. The requisite intermediate was obtained in $50 \%$ yield ${ }^{62}$.

A recent report by Chen and Joulli ${ }^{63}$ described the characterisation of the reaction product of D-ribonolactone with benzaldehyde in the presence of hydrochloric acid. They confirme that the product consisted exclusively of the 3,5-0-benzylidene derivative 71. It is therefore evident that glycosidation of alcohol 71 with the chlororibofuranoside 36 


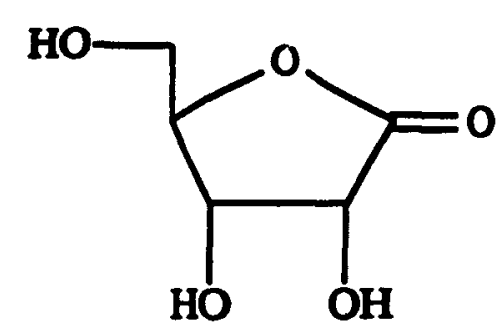

70

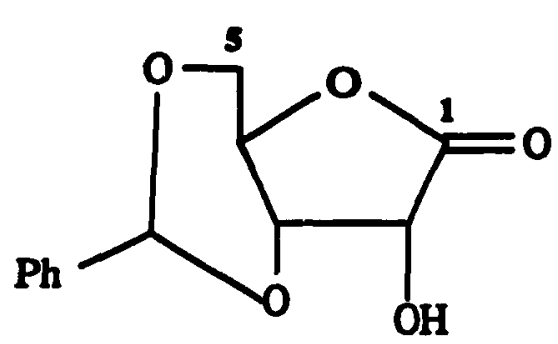

71

derived from orthoester 27 will afford a disaccharide which after reduction of the lactone and protecting group manipulations will afford the basic structure of 2-PRP (Scheme 9).

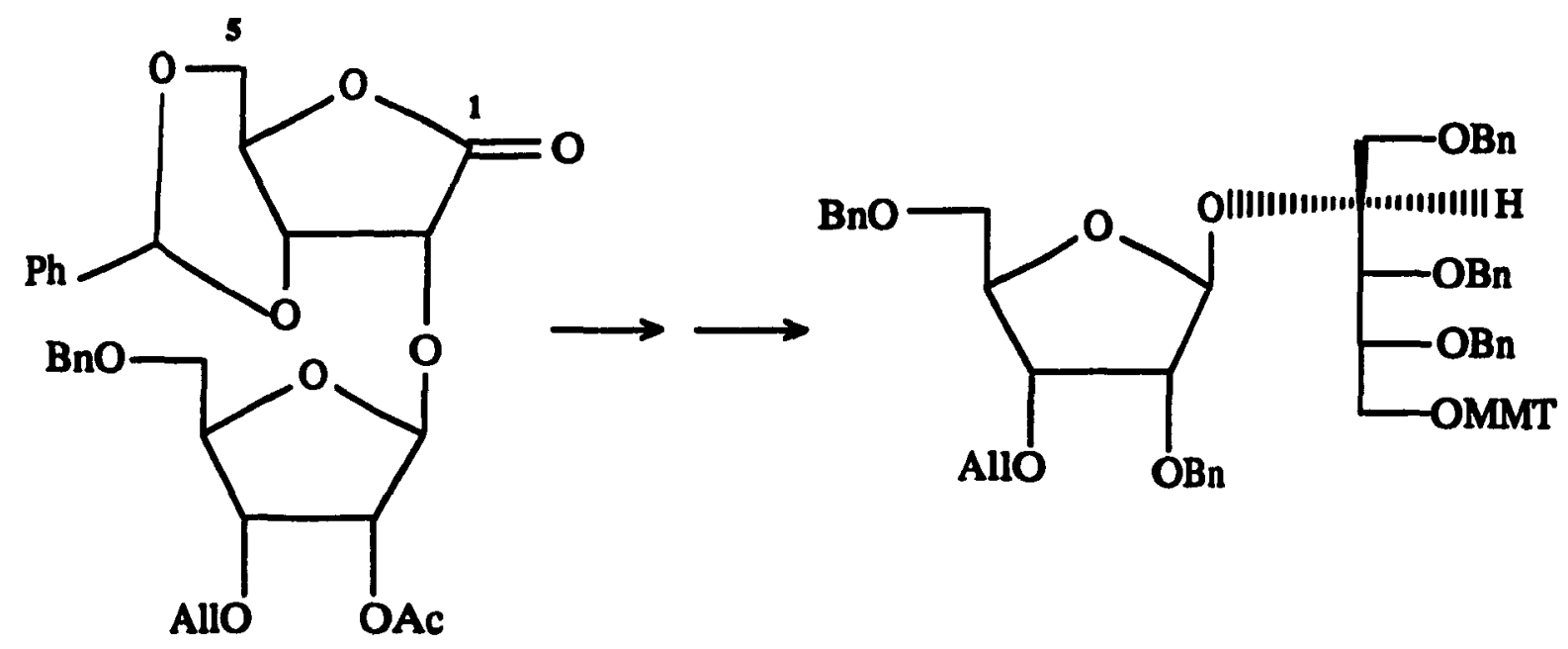

Scheme 9

The 3' and 5 hydroxy groups can also be deblocked independently from each other and can be functionalised as for the PRP synthesis.

The protected ribonolactone 71 was prepared according to the procedure of Chen and Joullie ${ }^{63}$ and was obtained in excellent yields as a crystalline pioduct. When the glycosidation under the previously described conditions was attempted, we were faced with an unexpected problem; the lactone was almost insoluble in all common organic solvents. 
The solubility in acetonitrile at $-40^{\circ} \mathrm{C}$, i.e. under the glycosidation conditions, was almost nil. Attempts at running the reaction at higher temperatures $\left(-20^{\circ} \mathrm{C}, 0^{\circ} \mathrm{C}, 22^{\circ} \mathrm{C}\right)$ were not very successful. The desired product was obtained in very low yields (< 15\%) and the reaction mixture also contained some unidentified products. The use of DMF as co-solvent was unsuccessful. It was evident that the lactone moiety was contributing to the insolubility of the compound. Therefore we sought an indirect approach where the lactone group was reduced at an earlier stage to give the suitably protected ribitol.

This implies that the 2-hydroxyl has to be protected first to enable the differentiation between the two secondary alcohols $(2-\mathrm{OH}$ and $4-\mathrm{OH})$ that will result from the reduction of the lactone. We also planned to mask the non participating hydroxyls as benzyl ethers. The choice of protecting group for the 2-hydroxyl was therefore determined by many factors; it must withstand hydride reducing agents and the strong basic conditions required to form benzyl ethers. Moreover, its formation and removal must be compatible with the fairly acid labile benzylidene group. Silyl ethers which are potential candidates were not selected because of possible migration during benzyl ethers formation. The highly acid labile 1-methyl-1-methoxethyl ether ${ }^{54}$ was selected instead.

A solution of lactone 71 in DMF was therefore treated with 2-methoxypropene and catalytic pyridinium $p$-toluenesulfonate at $0^{\circ} \mathrm{C}$. The desired ketal 72 was obtained in excellent yields as a crystalline material. Reduction of the lactone with sodium borohydride failed to give any product. We therefore resorted to lithium aluminum hydride as a reducing agent to yield the desired diol 73. Conversion to the benzyl ethers 74 followed by a brief treatment with $20 \%$ aqueous acetic acid yielded the key intermediate 75 in good yield.

Glycosidation of alcohol 75 with chlororibofuranoside 36 (derived from orthoacetate 


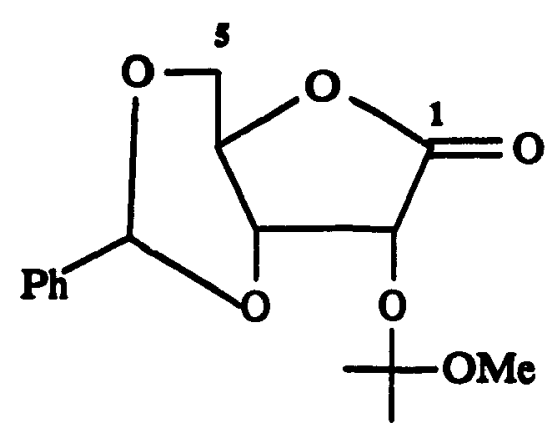

72

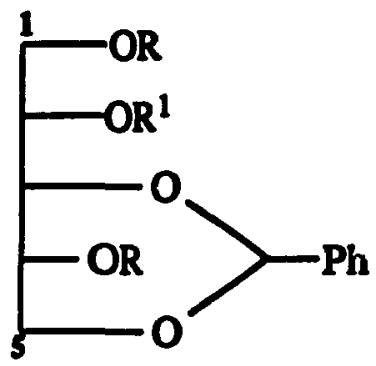

73. $\mathrm{R}=\mathrm{H}, \mathrm{R}^{1}=\mathrm{C}\left(\mathrm{CH}_{3}\right)_{2} \mathrm{OCH}_{3}$

74. $\mathrm{R}=\mathrm{Bn}, \mathrm{R}^{1}=\mathrm{C}\left(\mathrm{CH}_{3}\right)_{2} \mathrm{OCH}_{3}$

75. $R=B n, R^{1}=H$

27) gave a product which, we initially believed, was the 2-PRP derivative. Hydrolysis of the 2'-O-acetyl group with base followed by cleavage of the benzylidene group with aqueous trifluoroacetic acid gave a triol. The ${ }^{1} \mathrm{H}$ NMR of this compound showed three $\mathrm{D}_{2} \mathrm{O}$ exchangeable protons which appeared as sharp doublets indicating that all of them were secondary. Furthermore, monomethoxytritylation of this compound under standard conditions failed indicating the absence of any primary alcohols.

It therefore appeared that under the acidic condition of glycosidation, the 3,5-0-benzylidene of the ribitol migrated giving 2,3-0-benzylidene-1,4 di-0-benzyl-5-hydroxy ribitol (Scheme 10). As a result, the 5-hydroxyl reacted with the carbonium ion giving a 1-PRP derivative 76 with the ribitol in the L-configuration. Subsequent protecting group manipulations thus gave secondary alcohol 76a and finally triol 77.

This stategy was therefore abandoned until an alternative which avoids the use of acid sensitive masking groups could be found. 

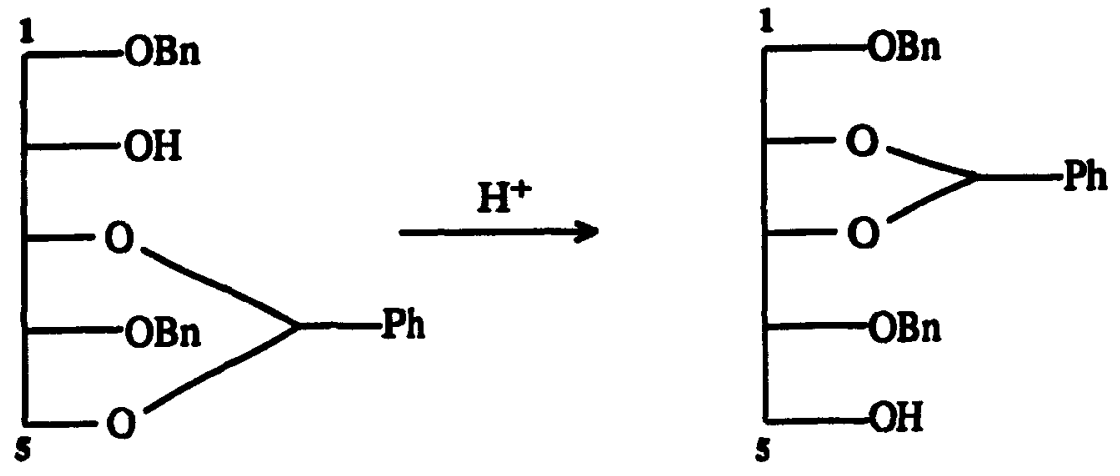

Scheme 10

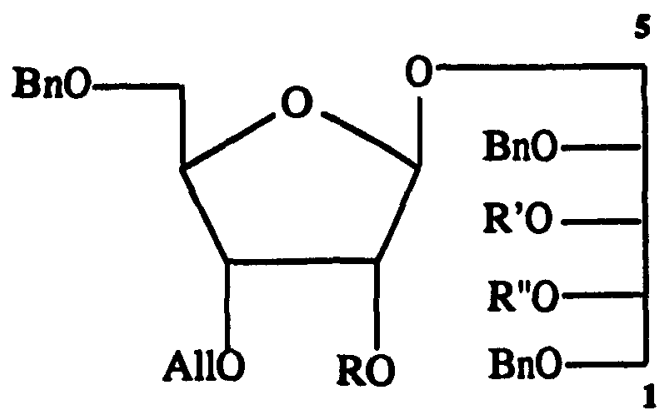

76. $R=A c, R^{\prime}, R^{\prime \prime}=C H P h$

76a. $R=H, R^{\prime}, R^{\prime \prime}=C H P h$

77. $R=R^{\prime}=R^{\prime \prime}=H$ 


\section{Chapter 4}

\subsection{Attempts at obtaining the ribosyl-ribitol molety by a more efficient approach.}

We have developed an efficient approach at securing the ribosyl-ribitol unit of PRP where the deprotection sequence is simplified. However, a fairly large number of steps involving protection-deprotection sequences are involved; we therefore sought to develop a more efficient approach which would be amenable to large scale synthesis.

This project arose from one interesting observation. We attempted the synthesis of 2,3-O-benzylidene D-ribofuranoside 54 by stirring a solution of ribose, benzaldehyde dimethyl acetal and camphorsulfonic acid (CSA) in DMF under water aspirator vacuum. We reasoned that the methanol formed would be removed under the reaction conditions thereby driving the reaction promptly to completion. The reaction was fast as expected but the crystalline product obtained gave a ${ }^{1} \mathbf{H}$ NMR which was not compatible with the expected product. No exchangeable protons could be detected even in dilute samples. Furthermore, integration indicated that the anomeric region contained three protons and the aromatic region had ten protons. We therefore concluded that the compound was 1,5:2,3-di-O-benzylidene $\beta$-D-ribofuranoside 78. The mass spectrum and elemental analysis of the compound confirmed our deductions. Reaction of D-ribose with p-methoxy benzaldehyde dimethyl acetal under similar conditions yielded the corresponding 1,5:2,3-di-O-( $p$-methoxybenzylidene) $\beta$-D-ribofuranoside 79. In this case, the reaction had to be catalyzed with pyridinium camphorsulfonate; the use of camphorsulfonic acid failed to give any of the desired product.

We realized that compound 78 or the more reactive p-methoxy derivative 79 had potential as the glysosyl acceptor for PRP synthesis. Our proposed scheme would require two selective acetal cleavages. The first one involves the opening of the 1,5 acetal 


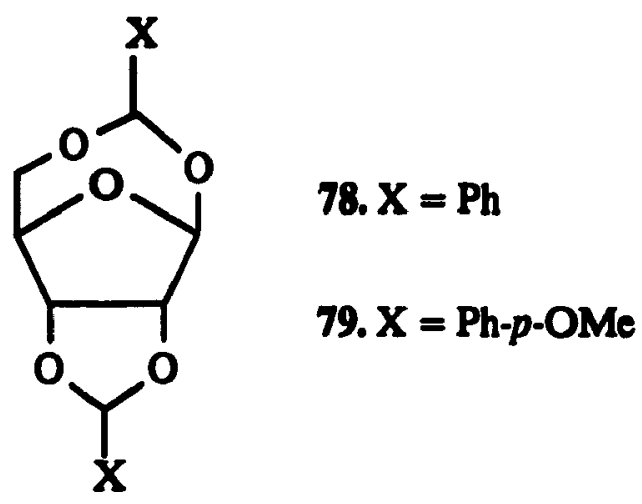

independently of the 2,3 acetal to give the 5-O-benzyl derivative (or the p-methoxybenzyl derivative). Glycosidation with ribitol 18 would therefore afford the ribosyl-ribitol unit. Opening of the 2, 3 acetal would then hopefully give the 2-O-benzyl derivative 42 (see page 29) or the corresponding $p$-methoxybenzyl compound as a major product (Scheme 11).

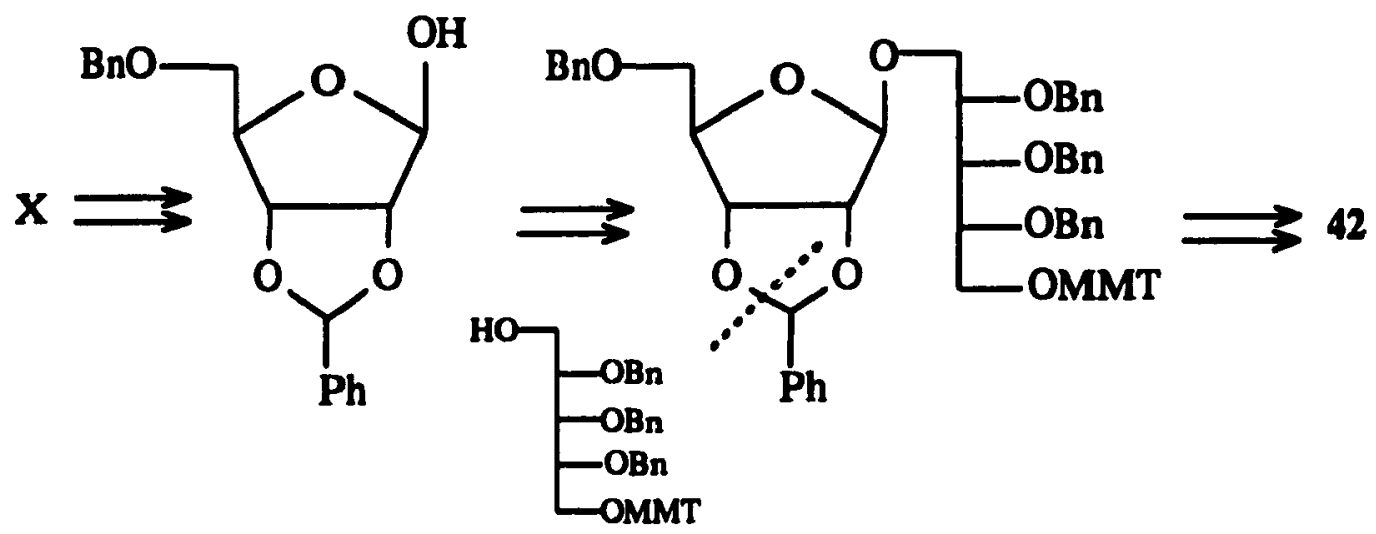

18

Scheme 11

Acetals have been traditionally cleaved by mixtures of a reducing agent and a Lewis acid. However, the opening of the 1,5 acetal will yield a ribose derivative in the hemiacetal form which is subject to further reduction. Therefore, reducing agents such as lithium aluminum hydride or sodium borohydride are to be avoided. Several authors have reported the use of sodium cyanoborohydride $\left(\mathrm{NaCNBH}_{3}\right)$ in conjunction with a Lewis acid such as TMSCl or trifluoroacetic acid to cleave p-methoxybenzylidene acetals $s^{54,56,57}$. High yields 
and stereospecificities were obtained. A useful property of $\mathrm{NaCNBH}_{3}$ is that it reduces aldehydes or ketones efficiently at low $\mathrm{pH}(<4)$ only58. Therefore, we reasoned that TMSCl might be the ideal Lewis acid for this type of cleavage.

Thus, TMSCl was added to solution of 78 and sodium cyanoborohydride in acetonitrile at $0^{\circ} \mathrm{C}$. TLC indicated the presence of two spots of similar Rf. After desilylation, the mixture was separated by chromatography yielding the desired product 80 and compound 52 obtained earlier in a 6:1 ratio. The overall yield was 56\%. The selectivity was promising but the yields were too low to be of any practical use. The low yield and poor regioselectivity was attributed to the lower reactivity of the benzylidene derivative compared to the $p$-methoxy counterpart. The next logical step was therefore to attempt this reaction on the corresponding di-p-methoxybenzylidene derivative 79.

The p-methoxy derivative was indeed more reactive, the 1,5-0-acetal could be opened at $-40^{\circ} \mathrm{C}$ and the reaction was over in less than one hour. As expected, the product was obtained in higher yields (65-75\%) and only the desired material 81 was obtained. The 2,3-O-acetal was also untouched. The identity of this compound could be easily be confirmed by ${ }^{1} \mathrm{H} \mathrm{N}_{v}$ : 2 . The anomeric proton appeared as a doublet which collapsed to a singlet upon treatment with $\mathrm{D}_{2} \mathrm{O}$ indicating that the hydroxyl lies on the anomeric carbon and exists exclusively as the $\beta$-anomer. Furthermore, the 2,3-0-( $p$-methoxybenzylidene) acetal existed as one isomer (possibly the more stable exo isomer). According to one report, the predominance of one isomer is determining in obtaining any regioselectivity in the cleavage of the acetal bond ${ }^{57}$.

\subsection{Approaches for glycosidation.}

The formation of the glycosyl bond could then be attempted. Recently, Schmidt 


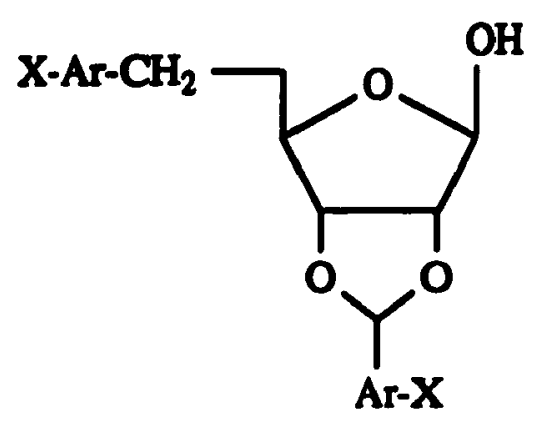

80. $X=H$

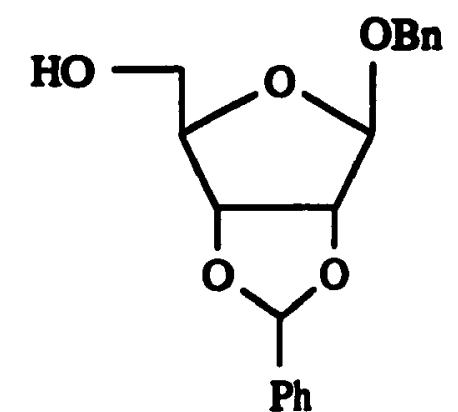

52

81. $X=p-O M e$

reported that furanoses such as $\mathbf{8 1}$ could be directly 1-0-alkylated by initially forming an alkoxide with a strong base such as sodium hydride or potassium $t$-butoxide. Reaction with an alkyl triflate then gave the alkyl glycoside in excellent yields and stereoselectivity ${ }^{66}$. Thus alcohol 18 was converted to the corresponding triflate $18 \mathrm{a}$ by the action of trifluoromethanesulfonic anhydride and triethyl amine. A solution of 81 in THF was treated with potassium $t$-butoxide and the triflate $18 \mathrm{a}$ was then added. No new products were formed; it seemed that 81 slowly decomposed under the basic conditions. Various bases such as sodium hydride and $n$-butyl lithium were used but to no avail.

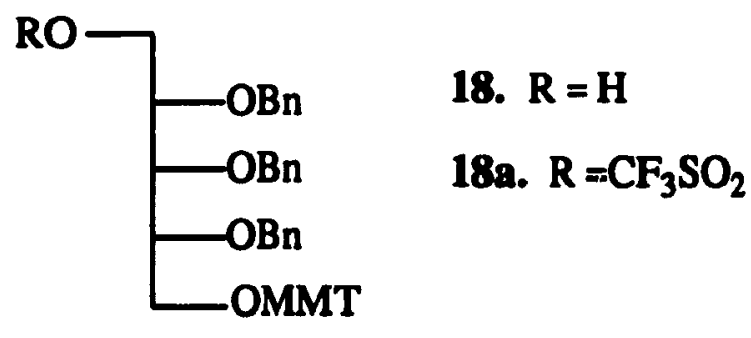

The anomeric alcohol 81 could also converted to the corresponding chloro-riboside 82 by treatment with methanesulfonyl chloride and an excess of tetraethylammonium chloride according to the procedure of Perlin ${ }^{67}$. This compound was found to be sufficiently stable to be purified by silica gel chromatography. However, Koenigs-Knorr 
glycosidation with ribitol 18 using silver perchlorate/collidine, silver carbonate, silver (I) oxide and silver acetate failed to give any desired products, perhaps due to the stability of 82 relative to a chloro 2-O-acetyl ribofuranoside derivative.

Recently, Fraser-Reid and Mcutoo ${ }^{68,69}$ reported that n-pentenyl pyranosides could be activated with iodonium dicollidine perchlorate $\left(\mathrm{I}^{+}\left(\mathrm{coll}_{2}\right)_{2} \mathrm{ClO}_{4}{ }^{-}\right)$giving a carbonium ion which upon addition of an alcohol gave the corresponding alkyl glycoside (Scheme 12).<smiles>[Y]C[C@]12CCC[O+]1[C@@H](OC)C([R20])[C@H]2[CH]C</smiles>

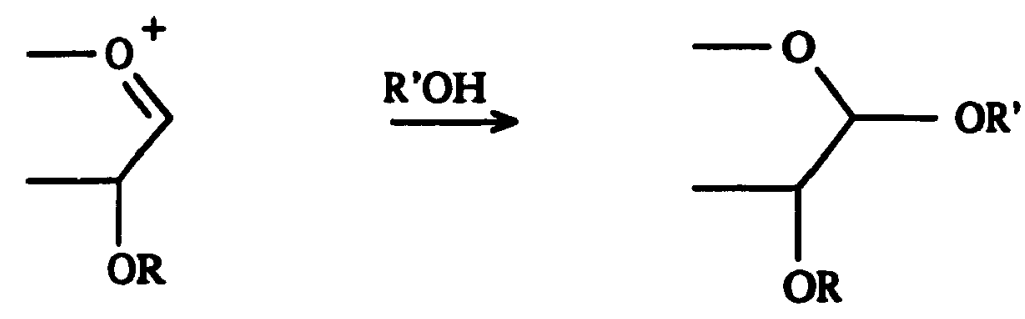

$\mathbf{R}=\mathrm{Bn}, \mathbf{T B D M S}$

Scheme 12

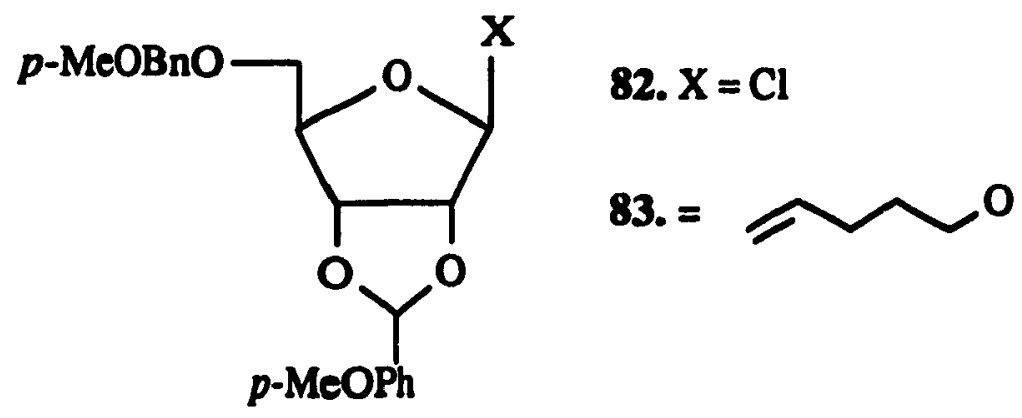

The alkyl pyranoside was isolated in $60 \%$ yield. However, there was no selectivity; the 
ratio of $\alpha / \beta$ anomers was 1:1.

We therefore reasoned that the pentenyl derivative 83 would be a suitable intermediate. The reaction medium was also reported to be neutral. The desired n-pentenyl glycoside 83 was then prepared in $\mathbf{4 0 \%}$ yield by a modification of a procedure described by Perlin ${ }^{67}$. Alcohol 79 was treated with mesyl chloride as for the preparation of 82 but an excess of tetra- $n$-butylammonium bromide was used instead. The resulting bromo glycoside was then treated with an excess of 4-penten-1-ol (5 eq) giving 83 in the $\beta$-anomeric form exclusively. When this reaction was attempted with the ribitol 18 (only a slight excess was used, $1.3 \mathrm{eq}$ ) no desired product was isolated. Interestingly, the methine (CH) proton of the p-methoxybenzylidene acetal 83 appeared as two singlets indicating that the acetal has rearranged under the weakly acidic conditions $\left(\mathrm{Et}_{3} \mathrm{~N} . \mathrm{HBr}\right.$ ). The pentenyl glycoside 83 was then treated with iodonium collidine perchlorate followed by ribitol 18. No desired products was obtained; instead some detritylation occured. The reaction was also attempted with the allyl ribitol 32 (page 25). At this stage, the approach involving 81 was abandoned due to failure to construct the ribosyl-ribitol moiety. 


\section{APPENDIX}

\section{Towards the synthesis of Goniothalenol}

Overview

It was found that the ethanolic extract of the stem bark of Goniothalamus giganteus (Annonaceae) was very toxic during the P388 in vivo antileukemic screen. Partitioning of the extracts between water and methylene chloride followed by chromatography gave several fractions, some of which were significantly toxic to brine shrimp. These fractions were further chromatographed yielding $0.43 \%$ of a compound which had a novel tetrahydrofurano-2-pyrone skeleton 84. The relative configuration of all the assymetric centers were determined by $\mathrm{X}$-ray analysis.

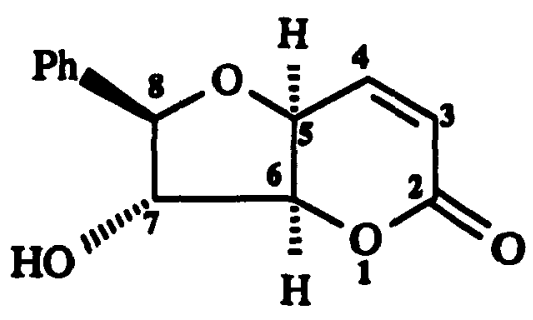

84

Retrosynthetic analysis

We approached this problem by envisaging bond disconnections depicted in Scheme 13. The lactone moiety can be derived from a tetrahydrofuran ring carrying an aldehyde and alcohol equivalent in the proper stereochemistry. The construction of the terahydrofuran ring can be thought of as a nucleophilic attack of the 5-hydroxyl on C-8 which bears a suitable leaving group. Further bond disconnections, namely introduction of the phenyl ring via a Grignard reaction on an aldehyde reveals that $\mathrm{C}-4$ to $\mathrm{C}-8$ backbone can be derived from diacetone glucose 85 . Furthermore, three of the four assymetric centers C-5, C-6 and C-7 originate from the glucose backbone, only the stereochemical outcome of C-8 remains to be determined.

The selection of the protecting group for the free hydroxyl of diacetone glucose is 

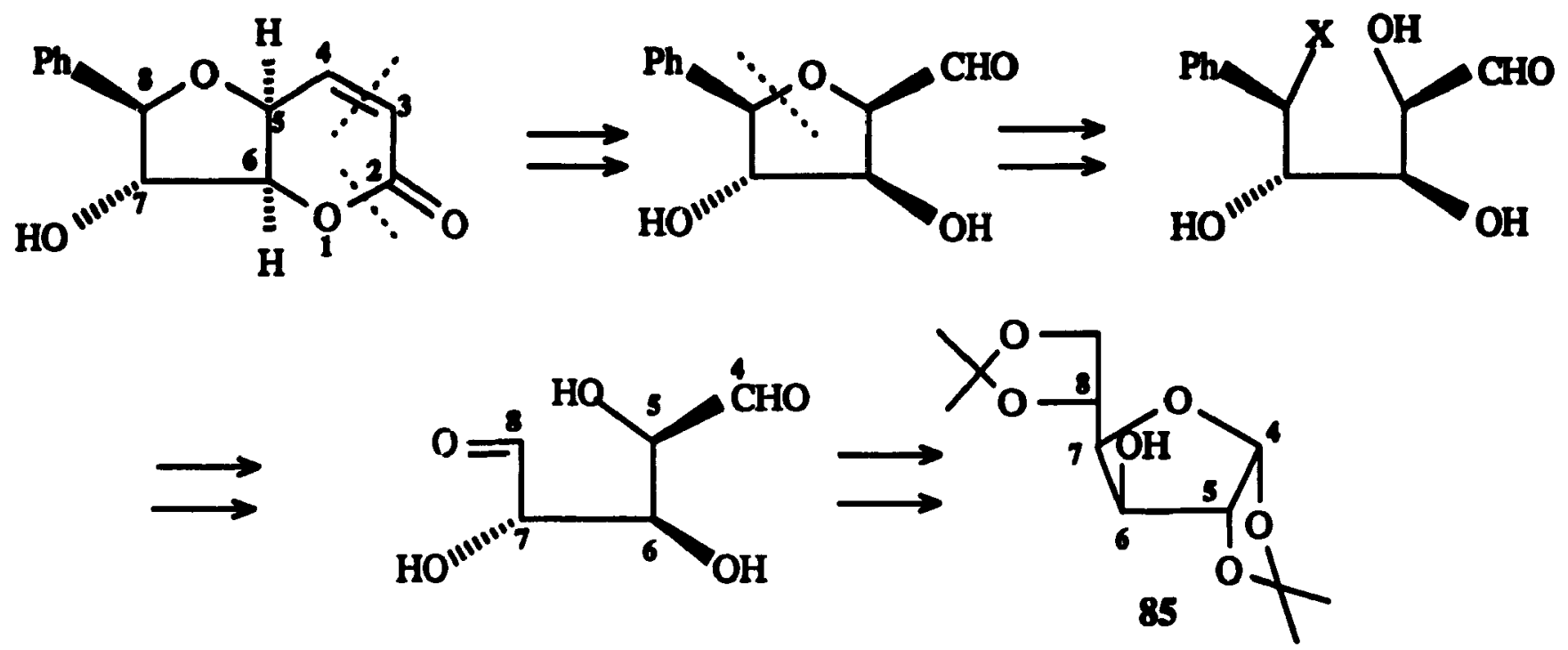

Scheme 13

not easy. The ideal one will be a benzyl ether since it can withstand a wide variety of conditions ranging from basic (Grignard reaction) to acidic for the formation of the tetrahydrofuran ring (See later). However, removal of the benzyl group might pose an insurmountable problem, Goniothalenol carries a secondary benzyl ether (C-8) which will most probably react under most debenzylation conditions.

Nevertheless, we decided to carry on with the benzyl ether, we reasoned that even if no selectivity can be obtained, this wrk will serve as useful model studies to secure the tetrahydrofuran ring. Diacetone glucose 85 was therefore benzylated according to the procedure of Czemecki et al ${ }^{35}$ giving 86. Selective hydrolysis of the 5, 6-0-isopropylidene group with 70\% aqueous acetic acid followed sodium periodate cleavage of diol 87 afforded aldehyde 88 in good yields. Treatment of 88 with phenyl cuprate yielded an easily separable mixture of two alcohols $89 \mathrm{a}$ and $89 \mathrm{~b}$ in approximately 1:1 ratio. At this stage the stereochemistry of the new assymmetric center was not known. Treatment of each isomer separately with ethanethiol/zinc chloride afforded triols $90 \mathrm{a}$ and $90 \mathrm{~b}$ in excellent yields. The formation of the tetrahydrofuran ring could then be attempted. We reasoned that C-8 
(goniothalenol numbering) being benzylic is prone to carbonium ion formation. Under dehydration conditions one could therefore expect the formation of stable carbonium ion at C-8 which would then be attacked by the 5-hydroxyl. In practice we could not find the right conditions to effect the ring closure. An alternative was therefore sought.

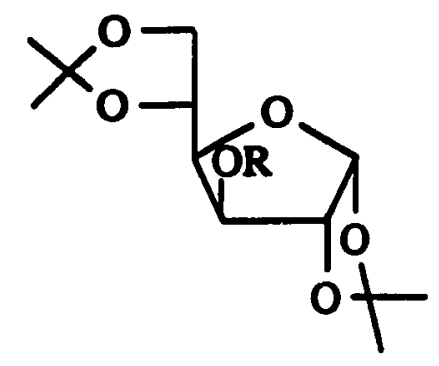

85. $R=H$

86. $R=B n$

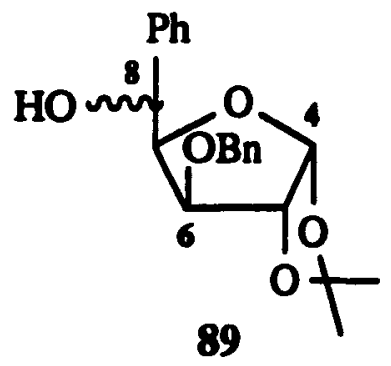

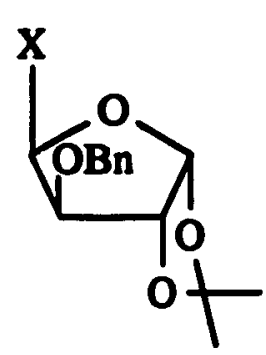

87. $\mathrm{X}=\mathrm{CH}(\mathrm{OH})-\mathrm{CH}_{2} \mathrm{OH}$

88. $\mathrm{X}=\mathrm{CHO}$

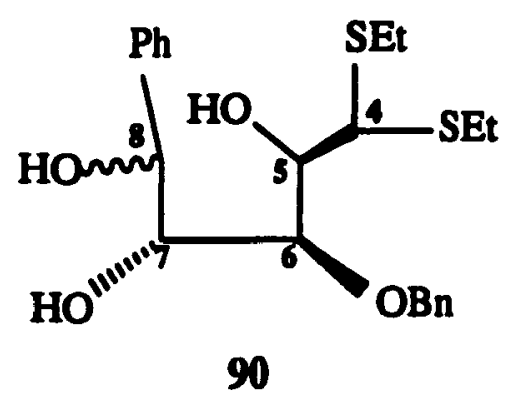

In a communication, Kelly and VanRheenen ${ }^{70}$ described an efficient prostaglandin synthesis from a cyclopropyl intermediate. It was found that the solvolysis of orthoesters of type 91 to give the rearranged alcohol 92 was best achieved with the use of anhydrous formic acid. We therefore reasoned that under similar conditions the 7,8-orthoformate of triol 90 might be converted to the benzylic carbonium ion which could react with the 5-hydroxyl thus effecting ring closure. The triol 90a was then treated with trimethyl orthoformate and pyridine hydrochloride in benzene yielding a 3.5:1 mixture of the 7,8and 5, 7 orthoformates 93. The 5-membered $(7,8)$ orthoformate was then isolated by chromatography and treated with anhydrous formic acid. After chromatography, the tetrahydrofuran 94 was isolated in about $45 \%$ yield. The 5,7-orthoformate also yielded 
similar products upon treatment formic acid indicating that rearrangement to the more stable 5-membered ring has occured.

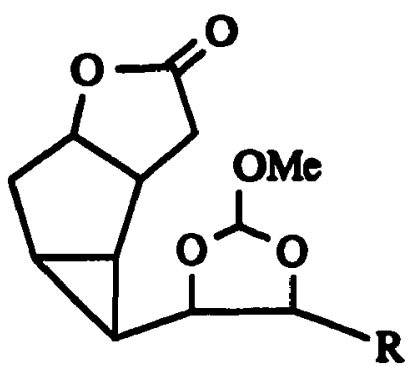

91

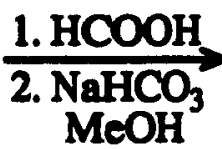

$\mathrm{MeOH}$

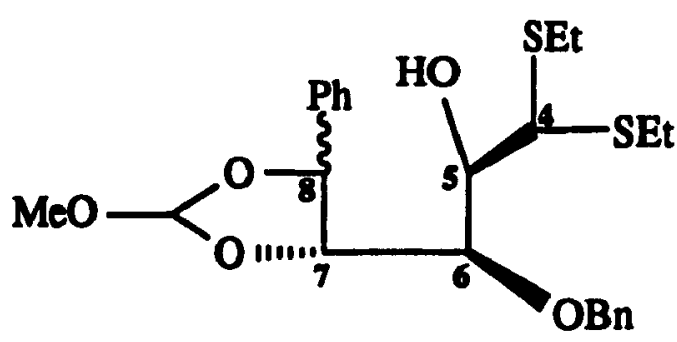

$+5,7$-isomer

93

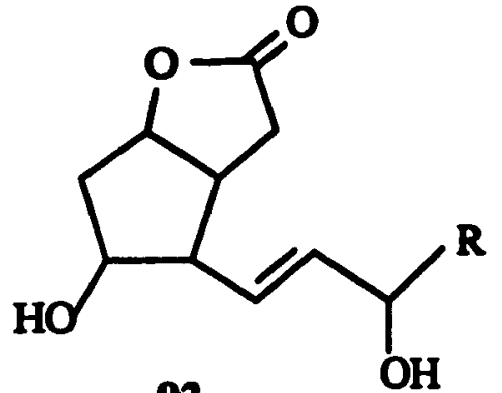

92

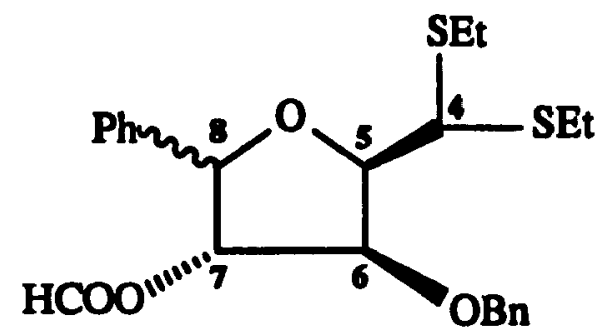

94

We have shown that the tetrahydrofuran ring of Goniothalenol can be constructed by our proposed scheme. However, debenzylation of the 6-hydroxyl can be problematic due to the presence of a secondary benzyl position (C-8) in the molecule. It was therefore decided to develop a new protecting group which might be suitable for the synthesis of Goniothalenol. This group must withstand both acidic (zinc chloride, formic acid) and basic conditions (phenyl cuprate) conditions. It occured to us that the ideal blocking group will be one which is initially stable to a variety of conditions but which can be converted to an unstable one once it has served its purpose.

In a recent communication Sekine and Hata described a novel protecting group, the 4, 4', 4"--tris(4, 5-dichlorophthalimido)trityl group 9571. This trityl group was very acid (80\% acetic acid, room temperature, $24 \mathrm{~h}$ ) stable compared to the trityl or monomethoxy 
trityl ethers. However, hydrolysis of the phthalimido groups with $1 \mathrm{M}$ hydrazine in pyridine-acetic acid buffer gave the extremely unstable $4,4^{\prime}, 4^{\prime \prime}$-triaminotrityl ether which decomposed in situ to the corresponding alcohol. Like all trityl ethers, 95 is very selective for primary alcohols; it will therefore not be useful for Goniothalenol synthesis. It occured<smiles>[R]OC(C)(C)c1ccc(N2C(=O)c3cc(Cl)c(Cl)cc3C2=O)cc1</smiles>

95

to us that the $p, p^{\prime}$-dinitrobenzhydryl ethers (DNB) might be a potential alternative. As opposed to trityl groups, benzhydryl ethers of secondary alcohols are readily formed. The DNB ether was expected to be as stable as a benzyl or benzhydryl ether yet reduction of the nitro groups should give an acid labile p,p'-diaminobenzhydryl ether (Scheme 14).

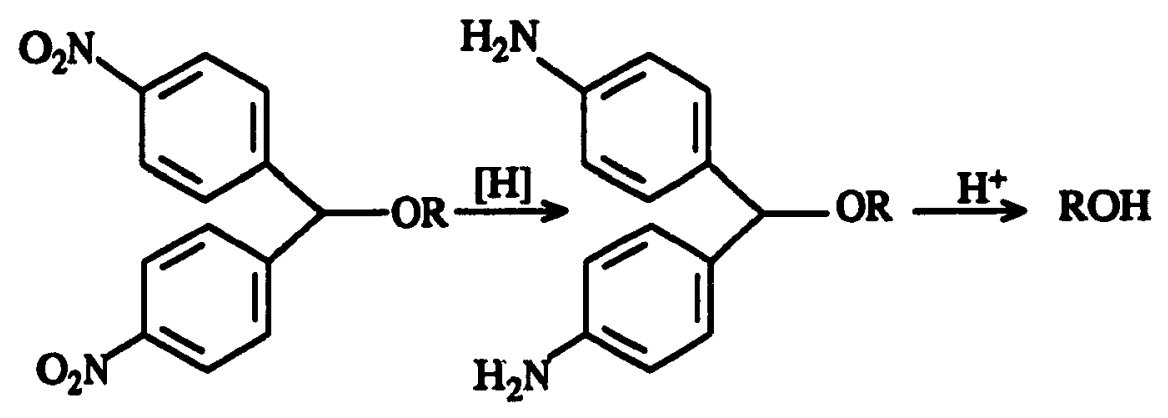

Scheme 14

Initially we attempted the synthesis of DNB ethers by the reaction of a sodium alkoxide (formed by reaction of an alcohol with sodium hydride in DMF) with the known p, $p^{\prime}$-dinitrobenzhydryl chloride72. Since the reaction did not proceed as expected, we investigated the usefulness of bis(p-nitrophenyl)diazomethane 98 as protecting agent. The 
latter was synthetized as follows. The benzophenone 96 was first prepared by the procedure of Kulin and Leffek ${ }^{72}$; diphenylmethane was selectively nitrated at the para position using a mixture of sulfuric and nitric acids. Oxidation with chromic acid yielded benzophenone 96 which was converted to the corresponding tosylhydrazone 97 with p-toluenesulfonhydrazide. Finally, the diazo compound was obtained as a red solid by heating a suspension of the tosylhydrazone 97 in $1 \mathrm{M}$ sodium hydroxide for $3 \mathrm{~h}^{73}$ (Scheme 15).
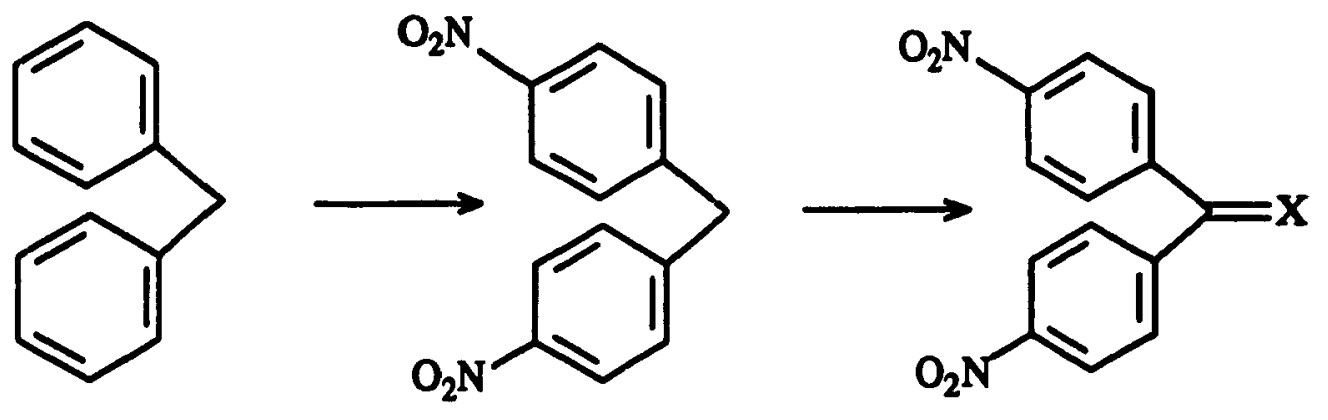

Scheme 15

96. $X=0$

97. $X=$ NNHTs

98. $\mathrm{X}=\mathrm{N}_{2}$

The conversion of an alcohol to its DNB ether was best carried out by adding 0.5-1.05 eq $\mathrm{BF}_{3} .0 \mathrm{Et}_{2}$ to a solution of alcohol $(1 \mathrm{eq})$ and diazo compound $98(1.2-1.5 \mathrm{eq})$ in methylene chloride at $-20^{\circ} \mathrm{C}$ to $25^{\circ} \mathrm{C}$. The reaction was usually complete in a few hours. Thus, the DNB ether of cholestanol 99, cholesterol 100, nonynol 101 and lactone 102 were obtained in 91-96\% yield. Interestingly, the protection of the 3-OH of 1,2:5,6-di-O-isopropylidene-D-glucose 85 did not proceed as expected. Instead $\mathrm{BF}_{3} . \mathrm{OE}_{2}$ catalyzed rearrangement of the isopropylidene group at 0-5,6 to 0-3,5 followed by etherification at 0-6 occured cleanly in good yield. Thus, only the ether 103 was isolated in 94\% yield by quenching the reaction with dry triethylamine. If quenching was carried out 
with water, the diol $85 a$ was obtained in $89 \%$ yield. Similarly, treatment of DNB ether 103 with $70 \%$ acetic acid at $40^{\circ} \mathrm{C}$ gave the diol $85 \mathrm{a}$ which was chracterized as its diacetate derivative; the ${ }^{1} H$ NMR spectrum showed the typical downfield shifts for only the H-3 (5.36 $\mathrm{ppm}, \mathrm{d})$ and $\mathrm{H}-5(5.21 \mathrm{ppm}, \mathrm{m})$. In order to test the selectivity of the reagent for primary versus secondary alcohols the easily obtained 3-O-tert-butyldiphenylsilyl derivative of $1,2-0$-isopropylideneglucofuranose $104^{74}$ was treated with reagent 98 . Only the ether 104a, obtained from mono derivatisation of the alcohol, was formed in $82 \%$ yield. 2,3,4-Tri-O-benzyl-D-ribose diethyl dithioacetal 105 was transformed to its DNB ether $105 \mathrm{a}$ in $97 \%$ yield. Hydrolysis of the dithioacetal function $\left(\mathrm{HgCl}_{2} / \mathrm{CdCO}_{3}\right)$ and reduction of the resulting aldehyde with sodium borohydride gave ribitol 106 in $84 \%$ yield. It was then converted by standard methods to its monomethoxytrityl ether 106a. Finally, the etherification of 1-adamantol 107 in moderate yield (80\%) is notable.

DNB ethers, similar to benzyl ethers and nitrobenzyl ethers are stable to a wide variety of conditions including strong acid, organometallic reagents, oxidizing agents, and some reducing agents (e.g., $\mathrm{NaBH}_{4}$ ). Selective cleavage of DNB ethers is possible in the presence of acetals, thioacetals, ketals, esters, as well as allyl, benzyl, THP, MEM, MTM, silyl and trityl ethers. Conversely, most of these protecting groups may be selectively removed in the presence of a DNB ether. The cleavage of DNB ethers to form the corresponding alcohols is best effected by catalytic hydrogenation $\left(\mathrm{H}_{2} / \mathrm{PtO}_{2}\right)$ of the ethers in aqueous methanol with or without cosolvent (e.g., THF) at $25^{\circ} \mathrm{C}$ at ambient pressure for a few hours. The resulting diaminobenzhydryl ethers were then hydrolysed by treatment with mild acid, such as a pH 3 or pH 4 buffer solution. Thus, the DNB ethers 99a, 103, 104a, 105a, 106a and 107a were cleaved to give the corresponding alcohols 99, 103a, 104, 105, 106b and 107 in good yields (Table 3). It is possible to cleave the DNB ethers having alkenyl or alkynyl functionalities such as $100 \mathrm{a}$ and $101 \mathrm{a}$ by using a different catalyst or a 

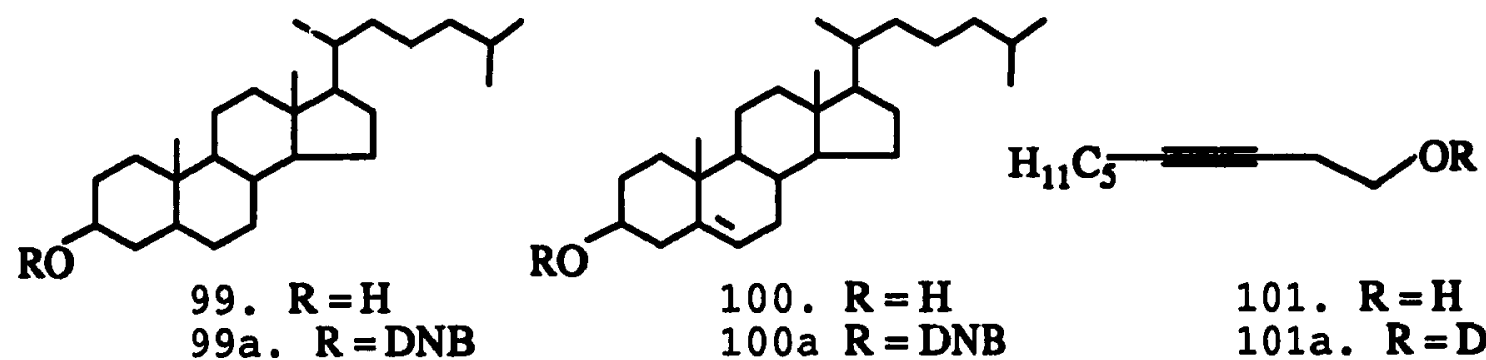

RO

$$
\begin{array}{ll}
\text { 100. } & R=H \\
\text { 100a } & R=D N B
\end{array}
$$

101. $R=H$

101a. $R=D N B$

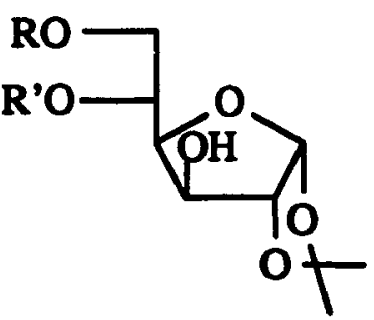

$$
\text { 85. } \mathrm{R}, \mathrm{R}^{\prime \prime}=\mathrm{CMe}_{2}
$$$$
\text { 85a. } R=D N B, R^{\prime}=H
$$

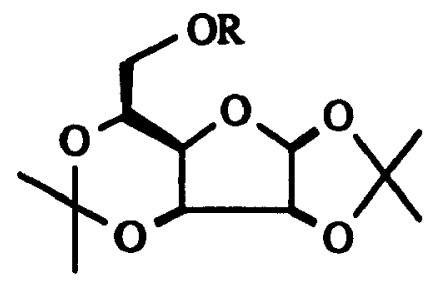

$$
\begin{aligned}
& \text { 102. } \quad R=H \\
& 102 a . \quad R=D N B
\end{aligned}
$$

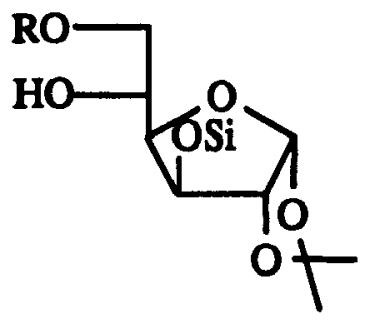

104. $R=H$

104a. $R=D N B$

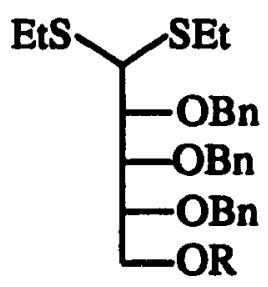

105. $R=H$

105a. $R=$ DNB
103. $\mathbf{R}=\mathrm{DNB}$

103a. $\mathbf{R}=\mathbf{H}$

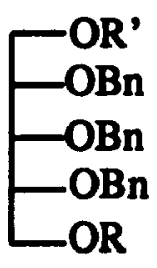

106. $R=D_{N B}, R^{\prime}=H$

106a. $R=D^{\prime}, R^{\prime}=M R$ 106b. $R=H, R^{\prime}=$ MMT

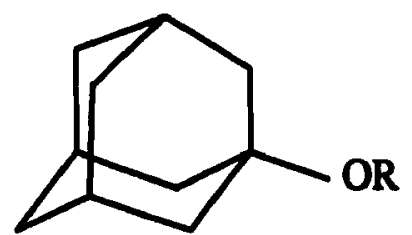

107. $R=H$

107a. $R=D N B$

$$
\mathrm{Si}=\mathrm{SiPh}_{2} \mathrm{Bu}-\mathrm{t}
$$

$\mathrm{DNB}=\mathrm{CH}\left(\mathrm{PhNO}_{2}-p\right)$ 
chemical reduction. Thus, the ether 100a was cleaved by hydrogenation using nickel boride $\left(\mathrm{Ni}(\mathrm{OAc})_{2} / \mathrm{NaBH}_{4}\right)$ as catalyst followed by mild acid hydrolysis (Table 3, entry 2$)^{75}$. The ether $101 a$ was cleaved with $\mathrm{Fe}_{3}(\mathrm{CO})_{12}$ in toluene-methanol ${ }^{76}$, followed by treatment with silica gel to afford the alcohol (Table 3, entry 3).

Table 3. Results from the Cleavage of DNB Ethers

\begin{tabular}{ccllcc}
\hline entry & substrates (RODNB) & reagents & solvents & products (ROH) & yields ${ }^{\mathrm{b}}, \%$ \\
\hline 1 & $99 \mathrm{a}$ & $\mathrm{H}_{2} / \mathrm{PtO}_{2}$ & $\mathrm{MeOH}-\mathrm{THF}$ & 99 & 89 \\
2 & $100 \mathrm{a}$ & $\mathrm{H}_{2} / \mathrm{Ni}_{2} \mathrm{~B}$ & EtOH-THF & 100 & 81 \\
3 & $101 \mathrm{a}$ & $\mathrm{Fe}_{3}(\mathrm{CO})_{12}$ & toluene & 101 & 85 \\
4 & $102 \mathrm{a}$ & $\mathrm{H}_{2} / \mathrm{PtO}_{2}$ & $\mathrm{MeOH}-\mathrm{THF}$ & 102 & 84 \\
5 & $103 \mathrm{a}$ & $\mathrm{H}_{2} / \mathrm{PtO}_{2}$ & $\mathrm{MeOH}-\mathrm{THF}$ & 103 & 82 \\
6 & $104 \mathrm{a}$ & $\mathrm{H}_{2} / \mathrm{PtO}_{2}$ & $\mathrm{MeOH}-\mathrm{H}_{2} \mathrm{O}$ & 104 & 84 \\
7 & $105 \mathrm{a}$ & $\mathrm{H}_{2} / \mathrm{PtO}_{2}$ & $\mathrm{MeOH}-\mathrm{H}_{2} \mathrm{O}$ & 105 & 85 \\
8 & $107 \mathrm{a}$ & $\mathrm{H}_{2} / \mathrm{PtO}_{2}$ & $\mathrm{MeOH}-\mathrm{THF}-\mathrm{H}_{2} \mathrm{O}$ & 107 & 90 \\
\hline
\end{tabular}

All products were identified by comparison with authentic samples. bIsolated yields.

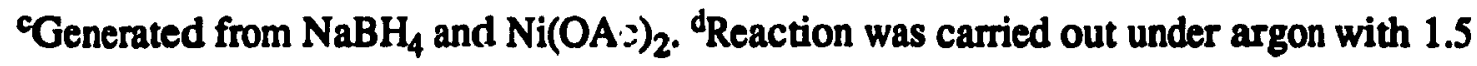
eq. of $\mathrm{Fe}_{3}(\mathrm{CO})_{12}$ and 5 eq. of $\mathrm{PhEt}_{3} \mathrm{NOH}$ (40\% in $\mathrm{MeOH}$ ) at room temperature for $2 \mathrm{~h}$, and then, after extractive workup, the mixture was acidified with silica gel. ${ }^{\circ}$ Obtained directly after hydrogenation.

In order to study the stability of the intermediate diaminobenzhydryl ether towards acid hydrolysis, various conditions for hydrolysis of $p p^{\prime}$-diaminobenzhydryl cholestanyl ether, obtained after hydrogenation of the DNB ether in neutral medium, were tested (Table 4). It was found to be stable at pH 5 but rapidly hydrolysed in $0.05 \%$ trifluoroacetic acid or $0.03 \mathrm{M}$ hydrogen chloride solution. Acidic resin and $0.05 \%$ acetic acid or $\mathrm{pH} 4$ buffer solution provided moderate acidic media, and the hydrolysis reaction was over in $6-8 \mathrm{~h}$ at room temperature. A very mild condition was found to be a pH 3 and $\mathrm{pH} 4$ buffer, in which 
the intermediate was hydrolysed smoothly to the alcohol and most other acid-labile groups, such as monomethoxytrityl unit, were not cleaved. For example, at pH 4 the DNB group of the fully protected ribitol 106a could be removed independently of the monomethoxytrityl group.

Table 4. Various Conditions for Acid Hydrolysis of $p, p^{\prime}$-Diaminobenzhydryl Cholestanylb Ether to Cholestanol 99a

\begin{tabular}{lcccccccc}
\hline reagents & $\mathrm{pH} 2$ & $\mathrm{pH} \mathrm{3}$ & $\mathrm{pH} \mathrm{4}$ & $\mathrm{pH} \mathrm{5}$ & $\mathrm{HCl}^{\mathrm{d}}$ & TFA $^{\mathrm{d}}$ & AcOH $^{\mathrm{e}}$ & resin $^{\mathrm{f}}$ \\
\hline $\mathrm{t}_{1 / 2}, \mathrm{~h}$ & 4 & 7 & 7 & $\mathrm{n} / \mathrm{r}$ & 0.5 & $<0.1$ & 3 & 3 \\
\hline
\end{tabular}

"All reactions were carried out in MeOH-THF (1:1 v/v) with same amount of starting material. bobtained from DNB ether $99 \mathrm{a}$ after hydrogenation $\left(\mathrm{H}_{2} / \mathrm{PtO}_{2}\right)$ in $\mathrm{MeOH}$-THF $(1: 1 \mathrm{v} / \mathrm{v}) .{ }^{9} 0.03 \mathrm{M} \mathrm{HCl} .{ }^{d} 0.05 \%$ trifluoroacetic acid (TFA). ${ }^{\circ} 0.05 \%$ AcOH ${ }^{f}$ Amberlite resin IRC-50 (H) from BDH. BMonitored by TLC, half life $\left(t_{1 / 2}\right)$ was obtained approximately from reaction time required for completion.

In conclusion, DNB ether has similar stabilities as benzyl or nitrobenzyl ether and be selectively cleaved in the presence of many other protecting groups.

Having developed a promising protecting group, we then focused our attention on the synthesis of Goniothalenol. However, we had to modify our strategy since 1,2:5,6-diisopropylidene $\alpha$-D-glucofuranose 85 reacts anomalously with the DNB group. We reasoned that the problem might probably be circumvented by the use of the known compound 10877, 78. After protecting the 3-hydroxyl group as its DNB ether, the double bond can be cleaved with ozone giving the aldehyde intermediate which can react with the phenyl Grignard reagent. At this point, Gesson ${ }^{79}, 80$ reported two syntheses of Goniothalenol, one of which was virtually identical to our earlier approach causing us to discontinue this project. 
72

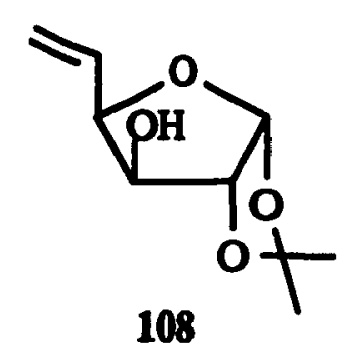




\section{Contribution to Knowledge}

1. A new and efficient approach to synthesize the ribosyl-ribitol unit of the capsular polysaccharide of Haemophilus influenzae type b bacteria was established.

2. The synthesis of oligomers of the polysaccharide attached to a ribose spacer was described. These compounds allows for a potential access to the development of an artificial vaccine against Haemophilus influenzae type b meningitis.

3. The preparation of a TBDMS protected ribose spacer and its subsequent deprotection by a new approach were described.

4. The development of a new hydroxyl protecting group was described. 


\section{EXPERIMENTAL}

\section{General Methods.}

Melting points were measured on Gallenkamp block and are uncorrected. Optical rotations were recorded on a Jasco DIP-140 digital polarimeter (Na lamp, 589 line) in chloroform unless specified otherwise. Thin-layer chromatography and flash chromatography were performed on Merck Silica Gel 60F 254 aluminum plates and Merck Silica Gel 60 (230-400 mesh) respectively. ${ }^{1} \mathrm{H}$ NMR spectra were obtained on Varian XL-200 and XL-300 spectrometers at 200 and $300 \mathrm{MHz}$ respectively. ${ }^{13} \mathrm{C}$ NMR spectra were recorded at 75.4 MHz on the Varian XL-300 spectrometer. Chemical shifts for both the ${ }^{1} \mathrm{H}$ and ${ }^{13} \mathrm{C}$ NMR are reported in $\delta$ units downfield of tetramethylsilane (TMS). ${ }^{31} \mathrm{P}$ NMR spectra were measured at $121.42 \mathrm{MHz}$ on a Varian XL-300 spectrometer using $5 \% \mathrm{H}_{3} \mathrm{PO}_{4}$ as external reference. All NMR spectra were obtained in chloroform-d $\left(\mathrm{CDCl}_{3}\right)$ unless specified otherwise. Low-resolution mass spectra (MS) were recorded on a HP 5984A or LKB 9000 spectrometers. High-resolution mass spectra were measured on a Du Pont 21-492B instrument.

All reactions were monitored by TLC and performed under an atmosphere of dry argon. Tetrahydrofuran (THF) was distilled from sodium and benzophenone prior to use. Methylene chloride was dried by refluxing over phosphorus pentoxide $\left(\mathrm{P}_{2} \mathrm{O}_{5}\right)$. Acetonitrile was distilled from $\mathrm{P}_{2} \mathrm{O}_{5}$ and refluxed over calcium hydride $\left(\mathrm{CaH}_{2}\right)$. Dioxane was distilled from $\mathrm{CaH}_{2}$. Tetrazole was purified by sublimation. Trichloroacetic acid was dried by distilling off the benzene-water azeotrope. 


\section{Chapter 2}

\section{Methyl 2,3-O-Isopropylidene- $\beta$-D-ribofuranoside. 21}

21 was prepared according to the method of Leonard and Carraway. J. Heterocycl. Chem. 1966, 3, 485.

\section{Methyl 5-O-benzyl-2,3-0-Isopropylidene- $\beta$-D-ribofuranoside 22.}

Sodium hydride (60\% oil dispersion, $10.20 \mathrm{~g}, 1.5 \mathrm{eq}$ ) was added to a solution of 21 $(50 \mathrm{~g})$ and tetra- $n$-butylammonium iodide $(0.90 \mathrm{~g}, 0.01 \mathrm{eq})$ in $500 \mathrm{ml}$ of dry THF. After complete evolution of hydrogen $(0.5 \mathrm{~h})$, benzyl bromide $(22 \mathrm{ml}, 1.2 \mathrm{eq})$ was slowly added. The mixture was stirred at room temperature for $6 \mathrm{~h}$. Florisil $(20 \mathrm{~g})$ was then added and the THF was removed under reduced pressure. Pentane $(200 \mathrm{ml})$ was then added to the slurry, filtration and washing the residue with $3 \times 200 \mathrm{ml}$ pentane followed by evaporation of the solvent gave an oil which was distilled to a colorless liquid (65 g, 90\%; Bp 130-135, 0.1 $\mathrm{mm} \mathrm{Hg}) .{ }^{1} \mathrm{H}$ NMR (200 MHz): 1.32, $1.49\left(2 \mathrm{~s}, 6 \mathrm{H}, 2 \mathrm{CH}_{3}\right), 3.29,\left(\mathrm{~s}, 3 \mathrm{H}, \mathrm{OCH}_{3}\right), 3.49(\mathrm{~m}$, $\left.2 \mathrm{H}, \mathrm{H}-5,5^{\prime}\right), 4.38$ (t, $\left.1 \mathrm{H}, \mathrm{H}-4, \mathrm{~J}=7.0 \mathrm{~Hz}\right), 4.55\left(\mathrm{~s}, 2 \mathrm{H}, \mathrm{CH}_{2} \mathrm{Ph}\right), 4.57$ (d, $1 \mathrm{H}, \mathrm{H}-2, \mathrm{~J}=$ $5.7 \mathrm{~Hz}$ ), 4.67 (d, $1 \mathrm{H}, \mathrm{H}-3, \mathrm{~J}=6.0 \mathrm{~Hz}), 4.97(\mathrm{~s}, 1 \mathrm{H}, \mathrm{H}-1), 7.34(\mathrm{~m}, 5 \mathrm{H}, \mathrm{ArH}) . \mathrm{MS}(\mathrm{CI}$, $\left.\mathrm{NH}_{3}, \mathrm{~m} / \mathrm{e}, \%\right) 312\left(\mathrm{M}+\mathrm{NH}_{4}{ }^{+}, 13.1\right), 280\left(\mathrm{M}+\mathrm{NH}_{4}{ }^{+}-\mathrm{MeOH}, 100\right)$.

\section{5-O-Benzyl 1,2,3 tri-O-acetyl-D-ribofuranoside 24.}

A solution of $22(26.25 \mathrm{~g})$ in $70 \%$ aqueous acetic acid $(120 \mathrm{ml})$ was heated to $80^{\circ} \mathrm{C}$ for $6 \mathrm{~h}$. Toluene was then evaporated from the solution until the smell of acetic acid could no longer be detected. The resulting oil was then dissolved in methylene chloride $(500 \mathrm{ml})$. To that solution was then added pyridine ( $36 \mathrm{ml}, 5 \mathrm{eq})$, DMAP $(1.0 \mathrm{~g}, 0.1 \mathrm{eq})$ followed by acetic anhydride $(34 \mathrm{ml}, 4 \mathrm{eq})$. After stirring for $0.5 \mathrm{~h}$ at room temperature, the excess acetic anhydride was quenched with methanol $(5 \mathrm{ml})$. The resulting solution was then washed with $1 \mathrm{~N} \mathrm{HCl}(200 \mathrm{ml})$, brine and dried over magnesium sulfate. Filtration of this 
suspension through a pad of silica gel eluting with ethyl acetate and removal of solvent under reduced pressure gave 24 as a pale yellow oil (quantitative). ${ }^{1} \mathrm{H}$ NMR (200 $\mathrm{MHz}$ ): $(\alpha / \beta, 25: 75)$ 1.90, 1.99, $2.05\left(\mathrm{~s}, 3 \mathrm{CH}_{3}\right), 3.58\left(\mathrm{~m}, 2 \mathrm{H}, \mathrm{H}-5,5^{\prime}\right), 4.29$ (m, $\left.1 \mathrm{H}, \mathrm{H}-4\right), 4.52$ (s, $2 \mathrm{H}, \mathrm{CH}_{2} \mathrm{Ph}$ ), 5.31 (d, $\left.1 \mathrm{H}, \mathrm{H}-3, \mathrm{~J}=3.7 \mathrm{~Hz}\right), 5.43(\mathrm{dd}, 1 \mathrm{H}, \mathrm{H}-2, \mathrm{~J}=4.7,6.5 \mathrm{~Hz}$ ), 6.09 (s, $H-1, \beta-H), 6.38(d, H-1, \alpha-H), 7.45(m, 5 H, A r-H)$.

\section{Orthoacetate 26.}

$200 \mathrm{ml}$ of dry methylene chloride saturated with anhydrous $\mathrm{HCl}$ at $0^{\circ} \mathrm{C}$ was added to a solution of $24(28 \mathrm{~g})$ in $25 \mathrm{ml}$ of methylene chloride. The solution was stirred for $18 \mathrm{~h}$ at $0^{\circ} \mathrm{C}$ and the solvent removed at reduced pressure. The acetic acid formed was then coevaporated with three portions of toluene $(100 \mathrm{ml})$. To a solution of the resulting oil in $200 \mathrm{ml}$ dry methylene chloride was then added dimethylformamide dimethylacetal (13.6 ml, $1.5 \mathrm{eq})$. After stirring for $3 \mathrm{~h}$ at $\mathrm{rt}$, the solution was filtered through a pad of silica gel and elution with ethyl acetate followed by removal of the solvent gave 26 as an oil ( $21 \mathrm{~g}, 80 \%)$. ${ }^{1} \mathrm{H}$ NMR (200 MHz): $1.59\left(\mathrm{~s}, 3 \mathrm{H}, \mathrm{CH}_{3}\right), 2.09\left(\mathrm{~s}, 3 \mathrm{H}, \mathrm{CO}_{2} \mathrm{CH}_{3}\right), 3.19\left(\mathrm{~s}, 3 \mathrm{H}, \mathrm{OCH}_{3}\right), 3.55$ (dd, $\left.1 \mathrm{H}, \mathrm{H}-5, \mathrm{~J}_{5-5^{x}}=11.1 \mathrm{~Hz}, \mathrm{~J}_{4.5}=4.1 \mathrm{~Hz}\right), 3.74\left(\mathrm{dd}, 1 \mathrm{H}, \mathrm{J}_{4-5^{\prime}}=2.5 \mathrm{~Hz}\right), 4.17(\mathrm{~m}, 1 \mathrm{H}$, $\mathrm{H}-4), 4.57\left(2 \mathrm{~d}, 2 \mathrm{H}, \mathrm{CH}_{2} \mathrm{Ph}, \mathrm{J}=12.1 \mathrm{~Hz}\right.$ ), 4.79 (dd, $1 \mathrm{H}, \mathrm{H}-3, \mathrm{~J} 34=5.3 \mathrm{~Hz}, \mathrm{~J}_{2-3}=8.8$ Hz),4.93 (t, $1 \mathrm{H}, \mathrm{H}-2, \mathrm{~J}=4.9 \mathrm{~Hz}), 5.96(\mathrm{~d}, \mathrm{H}-1, \mathrm{~J}=4.1 \mathrm{~Hz}), 7.32(\mathrm{~s}, 5 \mathrm{H}, \mathrm{ArH}) . \mathrm{MS}(\mathrm{CI}$, $\left.\mathrm{NH}_{3}, \mathrm{~m} / \mathrm{e}, \%\right): 356\left(\mathrm{M}+\mathrm{NH}_{4}^{+}, 36.7\right), 307\left(\mathrm{M}^{+} \cdot \mathrm{MeO}, 100\right)$.

\section{Orthoacetate 27.}

A solution of $26(21 \mathrm{~g})$ and sodium methoxide $(192 \mathrm{mg}, 0.1 \mathrm{equ}$.$) in 200 \mathrm{ml}$ methanol was stirred at it for $3 \mathrm{~h}$. The solvent was then removed at reduced pressure and replaced with THF (200 ml). Tetra- $n$-butylammonium iodide $(2.5 \mathrm{~g}, 0.1 \mathrm{eq})$ and sodium hydride ( $60 \%$ oil dispersion, $5.44 \mathrm{~g}, 2 \mathrm{eq}$ ) was then added to the solution of the alcohol and the mixture stirred for $1 \mathrm{~h}$. Allyl bromide $(12 \mathrm{ml}, 2 \mathrm{eq})$ was added and the mixture allowed 
to stir for $18 \mathrm{~h}$ at $\mathrm{nt}$. Water was carefully added and the mixture was concentrated in vacuo. The residue was dissolved in ether and the solution washed twice with brine, dried (Na, $\mathrm{SO}_{4}$ ) and concentrated. Flash chromatography of the residue (20\% ethyl acetate in hexanes) afforded the desired compound $(14 \mathrm{~g}, 77 \%)$ as a pale yellow oil. $[\alpha]^{23} \mathrm{D}+95.7$, (c 2.29, $\mathrm{CHCl}_{3}$ ). ${ }^{1} \mathrm{H} \mathrm{NMR}(200 \mathrm{MHz}): 1.70\left(\mathrm{~s}, 3 \mathrm{H}, \mathrm{CH}_{3}\right), 3.23$ (s, $\left.3 \mathrm{H}, \mathrm{OCH}_{3}\right), 3.60$ (dd, $1 \mathrm{H}$, $\left.\mathrm{H}-5, \mathrm{~J}_{5-5^{\circ}}=11.3 \mathrm{~Hz}, \mathrm{~J}_{4-5}=4.0 \mathrm{~Hz}\right), 3.82\left(\mathrm{~m}, 2 \mathrm{H}, \mathrm{H}-5^{\prime}, \mathrm{H}-3\right), 4.03\left(\mathrm{~m}, 3 \mathrm{H}, \mathrm{H}-4, \mathrm{CH}_{2}\right.$-vinyl), 4.59 (2 d, $\left.2 \mathrm{H}, \mathrm{CH}_{2} \mathrm{Ph}, \mathrm{J}=12.2 \mathrm{~Hz}\right), 4.69(\mathrm{t}, 1 \mathrm{H}, \mathrm{H}-2, \mathrm{~J}=4.4 \mathrm{~Hz}), 5.24(\mathrm{~m}, 2 \mathrm{H}$, vinylic- $\mathrm{CH}_{2}$ ), $5.90(\mathrm{~d}, 1 \mathrm{H}, \mathrm{H}-1, \mathrm{~J}=4.0 \mathrm{~Hz}$ ), $5.93(\mathrm{~m}, 1 \mathrm{H}$, vinylic-CH), $7.32(\mathrm{~s}, 5 \mathrm{H}, \mathrm{ArH})$. ${ }^{13}$ C NMR: $22.7\left(\mathrm{CH}_{3}\right), 49.5,68.0,71.4,73.4,77.4,78.1,78.7,104.2,117.9,124.7,127.7$, 128.4, 134.4, 137.0. MS (CI, $\left.\mathrm{NH}_{3}, \mathrm{~m} / \mathrm{e}, \%\right): 337\left(\mathrm{M}+\mathrm{H}^{+}, 10.9\right), 305\left(\mathrm{M}^{+} \cdot-\mathrm{MeO}, 100\right)$. HRMS ( $\left.\mathrm{Cl}, \mathrm{NH}_{3}, \mathrm{~m} / \mathrm{e}\right): \mathrm{C}_{18} \mathrm{H}_{25} \mathrm{O}_{6}\left(\mathrm{M}+\mathrm{H}^{+}\right)$calcd. 337.16524, found 337.16511.

\section{5-0-Allyl-2,3,4-tri-0-benzyl D-ribose diethyl dithioacetal 31.}

Sodium hydride (60\% oil dispersion) $(2.51 \mathrm{~g}, 1.5 \mathrm{eq})$ was added to a solution of 2,3,4-tri-O-benzyl D-ribose diethyl dithioacetal $31(22 \mathrm{~g})$ and tetra- $n$-butylammonium iodide $(1.545 \mathrm{~g}, 0.1 \mathrm{eq})$ in dry THF $(200 \mathrm{ml})$. After stirring the mixture for $1 \mathrm{~h}$ at $\mathrm{rt}$, allyl bromide ( $16 \mathrm{ml}, 3 \mathrm{eq}$ ) was added and allowed to react for $16 \mathrm{~h}$. Excess hydride was destroyed by careful addition of water. The oil resulting from the evaporation of the THF was dissolved in ether $(300 \mathrm{ml})$ and the solution washed with brine $(2 \times 200 \mathrm{ml})$, dried $\left(\mathrm{MgSO}_{4}\right)$ and concentrated to a yellow oil. (yield quantitative). The compound was used without purification in the next step. An analytical sample was purified by chromatography eluting with 5\% ether in petroleum ether. ${ }^{1} \mathrm{H}$ NMR $(200 \mathrm{MHz}) 1.15-1.26\left(\mathrm{~m}, 6 \mathrm{H}, 2 \mathrm{CH}_{3}\right)$, 2.57-2.71 (m, $4 \mathrm{H}, 2 \mathrm{SCH}_{2}$ ), 3.65-2.69 (m, $\left.2 \mathrm{H}, \mathrm{H}-5,5^{\prime}\right), 3.91-3.94\left(\mathrm{~m}, 2 \mathrm{H}, \mathrm{CH}_{2}\right), 3.99-4.16$ $(\mathrm{m}, 3 \mathrm{H}), 4.25$ (d, $1 \mathrm{H}, \mathrm{H}-1, \mathrm{~J}=3 \mathrm{~Hz}), 4.59-5.11$ (m, $\left.6 \mathrm{H}, \mathrm{PhCH}_{2}\right)$, 5.11-5.28 (m, $2 \mathrm{H}$, vinylic $\left.\mathrm{CH}_{2}\right)$, 5.81-5.89 (m, $1 \mathrm{H}$, vinylic $\left.\mathrm{CH}\right)$, 7.26-7.32 (m, $\left.15 \mathrm{H}, \mathrm{Ar}-\mathrm{H}\right)$. 


\section{Alternative method for the preparation of dithioacetal 31}

Methyl 5-0-allyl-2,3-0-isopropylidene- $\beta$-D-ribofuranoside 33.

Sodium hydride $(4.078 \mathrm{~g}, 1.5 \mathrm{eq})$ was added to a stirring solution of $21(16 \mathrm{~g}, 1 \mathrm{eq})$ and tetra-n-butylammonium iodide $(2.894 \mathrm{~g}, 0.1 \mathrm{eq})$ in $300 \mathrm{ml}$ dry THF at $\mathrm{rt}$. After $1 \mathrm{~h}$, allyl bromide ( $14 \mathrm{ml}, 2 \mathrm{eq}$ ) was added and stirring continued for $4 \mathrm{~h}$. Florisil $(20 \mathrm{~g}$ ) was then added to the reaction mixture and the solvent removed under vacuum. Pentane was then added to the residue filtration and evaporation of the pentane gave an oil which was distilled (BP 99-102 ${ }^{\circ} \mathrm{C}, 0.2 \mathrm{~mm} \mathrm{Hg}$ ) to a colorless oil (18.5 g, 97\%). ${ }^{1} \mathrm{H}$ NMR (200 MHz) 1.32, $1.4\left(2 \mathrm{~s}, 6 \mathrm{H}, 2 \mathrm{CH}_{3}\right), 3.32\left(\mathrm{~s}, 3 \mathrm{H}, \mathrm{OCH}_{3}\right), 3.34-3.53(\mathrm{~m}, 2 \mathrm{H}, \mathrm{H}-5,5), 4.02(\mathrm{~m}, 2 \mathrm{H}$, $\left.\mathrm{CH}_{2}\right), 4.34(\mathrm{~m}, 1 \mathrm{H}, \mathrm{H}-4), 4.58(\mathrm{~d}, 1 \mathrm{H}, \mathrm{H}-2, \mathrm{~J}=6 \mathrm{~Hz}), 4.68\left(\mathrm{dd}, 1 \mathrm{H}, \mathrm{H}-3, \mathrm{~J}_{3-2}=6 \mathrm{~Hz}, \mathrm{~J}_{3-4}=\right.$ $1 \mathrm{~Hz}), 4.97(\mathrm{~s}, 1 \mathrm{H}, \mathrm{H}-1), 5.16-5.34\left(\mathrm{~m}, 2 \mathrm{H}\right.$, vinylic $\left.\mathrm{CH}_{2}\right), 5.81-5.98(\mathrm{~m}, 1 \mathrm{H}$, vinylic $\mathrm{CH})$.

\section{Methyl 5-0-allyl- $\beta$-D-ribofuranoside 34}

A solution of compound $33(5 \mathrm{~g})$ in $200 \mathrm{ml}$ methanol and $25 \mathrm{ml}$ water containing 1 $\mathrm{ml}$ concentrated sulfuric acid was refluxed for $2 \mathrm{~h}$. The acid was quenched with saturated sodium bicarbonate solution and after evaporation of the methanol, the residue was extracted with ethyl acetate. The combined extracts were then washed with brine dried $\left(\mathrm{MgSO}_{4}\right)$ and concentrated to yield an anomeric mixture of the desired compound which was used without purification in the next step. ${ }^{1} \mathrm{H}$ NMR $(200 \mathrm{MHz})\left(\mathrm{CDCl}_{3}+\mathrm{D}_{2} \mathrm{O}\right) 3.30$ (s, $3 \mathrm{H}, \mathrm{OCH}_{3}$ ), 3.44-3.57 (m, $\left.2 \mathrm{H}, \mathrm{H}-5,5^{\prime}\right), 3.93-4.12(\mathrm{~m}, 5 \mathrm{H}), 4.78$ (s, 1H, H-1), 5.12-5.30 (m, $2 \mathrm{H}$, vinylic $\left.\mathrm{CH}_{2}\right), 5.80-5.89(\mathrm{~m}, 1 \mathrm{H}$, vinylic $\mathrm{CH}$ )

\section{5-0-Allyl D-ribose diethyl dithioacetal 35.}

Anhydrous zinc chloride $(2.357 \mathrm{~g}, 4 \mathrm{eq})$ was added to a solution of compound 34 (882 $\mathrm{mg}$ ) in ethanethiol ( $4 \mathrm{ml}$ ) at $\mathrm{rt}$. After stirring for $15 \mathrm{~min}$, the reaction was quenched 10 ml 0.1N HCl. The ethanethiol was then removed and the residue extracted with ethyl 
acetate. After drying $\left(\mathrm{MgSO}_{4}\right)$ and concentrating under vacuum, the compound was purified by chromatography eluting with $40 \%$ ethyl acetate in petroleum ether. (Yield $1.206 \mathrm{~g}, 94 \%)$. ${ }^{1} \mathrm{H}$ NMR (200 MHz) 1.27 (t, $\left.6 \mathrm{H}, 2 \mathrm{CH}_{3}\right), 2.61-2.78\left(\mathrm{~m}, 4 \mathrm{H}, 2 \mathrm{SCH}_{2}\right)$, 3.14-3.22 (m, $3 \mathrm{H}, 3 \mathrm{OH}), 3.70$ (m, $2 \mathrm{H}, \mathrm{CH}_{2}$ ), 3.86-4.00 (m, $5 \mathrm{H}$ ), 4.25 (d, $1 \mathrm{H}, \mathrm{H}-1, \mathrm{~J}=3$ $\mathrm{Hz})$, 5.17-5.31 (m, $2 \mathrm{H}$, vinylic $\left.\mathrm{CH}_{2}\right), 5.82-5.90(\mathrm{~m}, 1 \mathrm{H}, 3$ vinylic $\mathrm{CH})$

5-0-Allyl 2,3,4 tri-O-benzyl D-ribose diethyl dithioacetal 31.

Sodium hydride ( $60 \%$ oil dispersion, $9.73 \mathrm{~g}, 4 \mathrm{eq}$ ) was added to a solution of 35 (36 $\mathrm{g}, 1 \mathrm{eq})$ and tetra- $n$-butylammonium iodide $(11.23 \mathrm{~g}, 0.5 \mathrm{eq})$ in $50 \mathrm{ml}$ dry THF (1.3 l). After stirring for $1 \mathrm{~h}$ at $\mathrm{rt}$, benzyl bromide (28.9, 4 eq) was added and the stirring continued for 6 h. Florisil $(30 \mathrm{~g})$ was then added to the mixture and the THF was removed under vacuum. Pentane $(300 \mathrm{ml})$ was added and the mixture filtered through Celite washing the residue with pentane. After removal of the solvent, the oil was chromatographed (5\% ether in hexanes yelding $62.6 \mathrm{~g}(91 \%)$ of the desired compound. The ${ }^{1} \mathrm{H}$ NMR was superimposable on the spectrum of compound 31 prepared earlier.

\section{5-0-Allyl-2,3,4-tri-O-benzyl D-ribitol 32.}

Mercury (II) chloride ( $30 \mathrm{~g}, 2.5 \mathrm{eq}$ ) was added to a stirring suspension of mercury (II) oxide (yellow) (29 $\mathrm{g}, 2.5 \mathrm{eq})$ in a solution of $32(25 \mathrm{~g})$ in $10 \%$ aqueous acetone (500 $\mathrm{ml}$ ) at $\mathrm{rt}$. After $2 \mathrm{~h}$, the mixture was filtered through Celite washing with acetone. The residue obtained after removing the solvent was taken in methylene chloride $(400 \mathrm{ml})$ and washed with $10 \%$ potasium iodide solution $(3 \times 200 \mathrm{ml})$, brine, dried $\left(\mathrm{MgSO}_{4}\right)$ and concentrated. The resulting oil was then dissolved in methanol $(500 \mathrm{ml})$ and sodium borohydride $(3.36 \mathrm{~g}, 2 \mathrm{eq})$ was slowly added to the solution. After complete addition, the solution was evaporated to dryness and the residue was dissolved in methylene chloride $(400 \mathrm{ml})$. This solution was washed with brine $(2 \times 200 \mathrm{ml})$, dried $\left(\mathrm{MgSO}_{4}\right)$ and the solvent 
was removed in vacuo. The residue was purified by flash chromatography eluting with $25 \%$ ether in petroleum ether yielding 32 as a pale yellow oil; (yield $14.7 \mathrm{~g}, 72 \%$ )

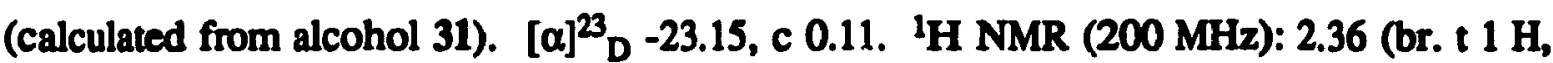
OH), 3.63-3.99 (m, $9 \mathrm{H}), 4.61-4.79\left(\mathrm{~m}, 6 \mathrm{H}, \mathrm{CH}_{2} \mathrm{Ph}\right), \quad 5.20-5.33\left(\mathrm{~m}, 2 \mathrm{H}\right.$, vinylic $\left.\mathrm{CH}_{2}\right)$, 5.84-5.98 (m, $1 \mathrm{H}$, vinylic CH), 7.33 (m, $15 \mathrm{H}, \mathrm{ArH}) . \mathrm{MS}$ (CI, $\left.\mathrm{NH}_{3}, \mathrm{~m} / \mathrm{e}, \%\right)$ : $463\left(\mathrm{M}+\mathrm{H}^{+}\right.$, 100). HRMS ( $\left.\mathrm{CI}, \mathrm{NH}_{3}\right)$ for $\mathrm{C}_{29} \mathrm{H}_{35} \mathrm{O}_{5}\left(\mathrm{M}+\mathrm{H}^{+}\right)$Calcd. 463.24836 Found 463.24845.

\section{2'-0-Acetyl-3'-0-allyl-5'-0-benzyl- $\beta$-ribofuranosyl}

\section{2,3,4-tri-0-benzyl-5-O-allyl-D-ribitol 37.}

Freshly distilled trimethylsilyl chloride (TMSCl) was added to a solution of orthoacetate $27(6.75 \mathrm{~g}, 20.10 \mathrm{mmol})$ in dry methylene chloride $(200 \mathrm{ml})$ at $\mathrm{rt}$. After stirring the solution for $\mathrm{lh}$, the solvent and excess TMSCl were removed under vacuum. A solution of the resulting oil in dry acetonitrile $(20 \mathrm{ml})$ was then added to a suspension solution of silver perchlorate $(4.57 \mathrm{~g}, 22.10 \mathrm{mmol})$ and finely powdered $4 \mathrm{~A}$ molecular sieves $(9 \mathrm{~g})$ in dry acetonitrile $(60 \mathrm{ml})$ at $-40^{\circ} \mathrm{C}$ and the mixture was stirred for $1 \mathrm{~h}$. The ribitol $32(4.64 \mathrm{~g}$, $10.05 \mathrm{mmol})$ in acetonitrile $(20 \mathrm{ml})$ was slowly added to the suspension. After $4 \mathrm{~h}$ at $-40^{\circ} \mathrm{C}$, solid sadium bicarbonate $(3 \mathrm{~g})$ was added and the solids were filtered through Celite washing with methylene chloride $(200 \mathrm{ml})$. Removal of the solvents and chromatography (15\% ether in hexanes) gave a colorless oil $(6.42 \mathrm{~g}, 83 \%)$. $[\alpha]^{23} \mathrm{D}-18.15,\left(: 1.29, \mathrm{CHCl}_{3}\right)$. ${ }^{1} \mathrm{H}$ NMR (200 MHz) $2.14\left(\mathrm{~s}, 3 \mathrm{H}, \mathrm{COCH}_{3}\right), 3.56-3.68(\mathrm{~m}, 5 \mathrm{H}), 3.71-4.21(\mathrm{~m}, 10 \mathrm{H})$, 4.50-4.73 (m, $8 \mathrm{H}, \mathrm{CH}_{2} \mathrm{Ph}$ ), 4.90 (s, $\left.1 \mathrm{H}, \mathrm{H}-1\right), 5.14-5.33$ (m, $5 \mathrm{H}, 2$ vinylic $\mathrm{CH}_{2}, \mathrm{H}-2$ ), 5.64-5.94 (m, $2 \mathrm{H}$, vinylic $\mathrm{CH}), 7.32(\mathrm{~m}, 20 \mathrm{H}, \mathrm{Ar}-\mathrm{H}) .{ }^{13} \mathrm{C} \mathrm{NMR:} 20.9\left(\mathrm{CH}_{3}\right), 67.4,69.9$ 71.6, 71.94, 72.3, 72.4, 73.2, 73.9, 74.2, 78.0, 78.2, 78.6, 80.4, 105.2 (C-1), 116.9, 117.6, $127.6,127.8,127.9,128.0,128.3,134.2,134.9,138.3,138.5,138.6,170.0$ (-COO-).

\section{2,5-Di-0-benzyl-3-0-allyl-ß-ribofuranosyl 2,3,4-tri-O-benzyl-5-O-allyl-D-ribitol 38.}

Sodium methoxide $(21 \mathrm{mg}, 0.1 \mathrm{eq})$ was added to solution of $37(3 \mathrm{~g})$ in methanol. 
After $2 \mathrm{~h}$ at $\mathrm{\pi}$, the methanol was removed under reduced pressure. Sodium hydride (60\% oil dispersion, $0.251 \mathrm{~g}, 1.6 \mathrm{eq})$ and tetra-n-butylammonium iodide $(0.723 \mathrm{~g}, 0.5 \mathrm{eq})$ was then added to a solution of the resulting oil in dry THF $(50 \mathrm{ml})$. After stirring for $1 \mathrm{~h}$ at $\mathrm{rt}$, benzyl bromide $(0.64 \mathrm{ml}, 1.3 \mathrm{eq})$ was added and stirring continued overnight. The reaction was then quenched with water. The THF was then removed under vacuum and a solution of the residue in methylene chloride $(200 \mathrm{ml})$ was then washed with brine $(2 \times 100 \mathrm{ml})$ dried $\left(\mathrm{MgSO}_{4}\right)$ and concentrated to dryness. Chromatography (25\% ether in hexanes) yielded 38. ${ }^{1} \mathrm{H}$ NMR (200 MHz): $3.54-3.70(\mathrm{~m}, 5 \mathrm{H}), 3.95-4.00(\mathrm{~m}, 10 \mathrm{H}), 4.30(\mathrm{~m}, 1 \mathrm{H}, \mathrm{H}-4)$, 4.49-4.68 (m, $10 \mathrm{H}, \mathrm{CH}_{2} \mathrm{Ph}$ ), 5.04 (s, $\left.1 \mathrm{H}, \mathrm{H}-1\right), 5.13-5.31$ (m, $4 \mathrm{H}, 2$ vinylic $\left.\mathrm{CH}_{2}\right), 5.89$ (m, $2 \mathrm{H}, 2$ vinylic $\mathrm{CH}), 7.24-7.37$ (m, $25 \mathrm{H}, \mathrm{Ar}-\mathrm{H}) .{ }^{13} \mathrm{C}$ NMR: 67.3, 70.1, 71.5, 71.8, 72.1, 72.2, 72.3, 72.5, 73.1, 73.9, 78.1, 78.5, 78.7, 78.8, 79.6, 80.5, 105.4 (C-1), 116.8, 117.4, $127.5,127.6,127.8,127.9,128.0,128.3,128.4,134.5,135.0,137.9,138.5,138.6,138.7$

\section{2,5-Di-0-benzyl- $\beta$-ribofuranosyl 2,3,4-tri-0-benzyl-D-ribitol 41.}

A solution of 38 ( $5.921 \mathrm{~g}, 7.27 \mathrm{mmol})$, tris(triphenylphosphine)rhodium(I) chloride $(0.673 \mathrm{~g}, 0.727 \mathrm{mmol})$ and DABCO $(0.244 \mathrm{~g}, 2.18 \mathrm{mmol})$ in $75 \mathrm{ml}$ of $10 \%$ aqueous ethanol and $25 \mathrm{ml}$ toluene was refluxed for $6 \mathrm{~h}$. NMR showed complete disappearance of the allyl pattern. The solvents were then replaced with $10 \%$ aqueous acetone $(100 \mathrm{ml})$ and to that solution was added mercury (II) chloride $(5.925 \mathrm{~g}, 21.82 \mathrm{mmol})$ and mercury (II) oxide $(4.727 \mathrm{~g}, 21.82 \mathrm{mmol})$. After stirring the suspension for $1 \mathrm{~h}$, the solids were removed by filtration through Celite. Removal of acetone under reduced pressure gave an oil which was then dissolved in methylene chloride $(300 \mathrm{ml})$. This solution was then washed with $5 \%$ potassium iodide solution $(2 \times 100 \mathrm{ml})$, brine $(100 \mathrm{ml})$, dried $\left(\mathrm{MgSO}_{4}\right)$ and concentrated to dryness. Purification by chromatography (50\% ether in hexanes) gave 41 as an oil ( $3.875 \mathrm{~g}$, 65\%). [a] ${ }^{23} \mathrm{D}^{3.15}$, (c 0.93, $\mathrm{CHCl}_{3}$ ). ' ${ }^{1} \mathrm{H}$ NMR (200 MHz): 2.29 (br t, $1 \mathrm{H}, \mathrm{C5}$ '-OH, 2.60 (d, $1 \mathrm{H}, \mathrm{C} 3-\mathrm{OH}, \mathrm{J}=8.5 \mathrm{~Hz}), 3.50-4.17(\mathrm{~m}, 12 \mathrm{H}), 4.48-4.69\left(\mathrm{~m}, 10 \mathrm{H}_{,} \mathrm{CH}_{2} \mathrm{Ph}\right), 5.01(\mathrm{~s}, 1 \mathrm{H}$, 
$\mathrm{H}-1)$, 7.28-7.32 (m, $25 \mathrm{H}, \mathrm{Ar}-\mathrm{H}) .{ }^{13} \mathrm{C}$ NMR: 61.4, 67.1, 71.7, 71.9, 72.3, 72.6, 73.2, 74.0, 77.8, 78.9, 79.1, 81.7, 83.1, 104.8 (C-1), 127.5, 127.7, 127.8, 128.1, 128.1, 128.3, 128.4, $128.6,137.1,138.0,138.1$.

Alernative method for the preparation of 2,5-Di-O-benzyl- $\beta$-ribofuranosyl 2,3,4-tri-0-benzyl-D-ribitol 41.

Lithium triethylborohydride (Super Hydride $\left.{ }^{(}\right)$(1.9 ml (1.0M in THF), $1.9 \mathrm{mmol}$ ) was added to a solution of $38(190 \mathrm{mg}, 0.23 \mathrm{mmol})$, tetrakis(triphenylphosphine)palladium(0) (135 $\mathrm{mg}, 0.12 \mathrm{mmol}$ ) and triphenylphosphine (86 $\mathrm{mg}, 0.33 \mathrm{mmol}$ ) in anhydrous dioxane $(5 \mathrm{ml})$. The solution was refluxed for $1 \mathrm{~h}$. TLC analysis showed complete absence of starting material and the appearance of a new polar spot having the same $R f$ as diol 41 . After quenching the reaction with $2 \mathrm{ml}$ of a $1 \mathrm{M} \mathrm{NaOH}$ solution, the dioxane was removed under vaccum. The residue was then taken in chloroform and washed with brine. Drying followed by concentration afforded an nil which v. as then purified by chromatography (25\% ethyl acetate in petroleum ether). Yield: $154 \mathrm{mg}$ (90\%). The ${ }^{1} \mathrm{H}$ NMR was indistinguishable from the NMR of the compound obtained from the other deallylation procedure.

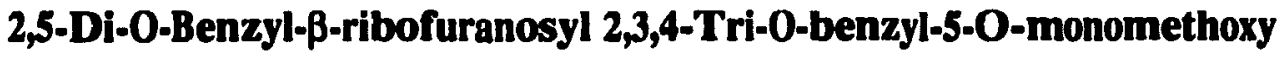 trityl-D-ribitol 42.}

Monomethoxytrityl chloride ( $1.985 \mathrm{~g}, 1.3 \mathrm{eq})$ was added to a solution of 41 (3.609 $\mathrm{g})$, dry pyridine $(1.20 \mathrm{ml}, 3 \mathrm{eq})$ and DMAP $(0.302 \mathrm{~g}, 0.5 \mathrm{eq})$ in dry methylene chloride (55 $\mathrm{ml}$ ) at $\mathrm{rt}$. After stirring for $15 \mathrm{~h}$, the solution was poured into saturated sodium bicarbonate solution. The aqueous layer was further extracted with methylene chloride, the combined extracts were then washed with brine, dried $\left(\mathrm{Na}_{2} \mathrm{SO}_{4}\right)$ and concentrated to dryness. Chromatography gave 41 as a white foam $(4.513 \mathrm{~g}, 86 \%)$. [a] ${ }^{23} \mathrm{D}-15.4,\left(\mathrm{c} 1.27, \mathrm{CHCl}_{3}\right)$. 
${ }^{1} \mathrm{H}$ NMR (200 MHz): 2.57 (d, $1 \mathrm{H}, \mathrm{C} 3-\mathrm{OH}, \mathrm{J}=8.7 \mathrm{~Hz}$ ), 3.41-4.10 (m, $\left.12 \mathrm{H}\right), 3.75(\mathrm{~s}, 3 \mathrm{H}$, $\left.\mathrm{OCH}_{3}\right)$, 4.47-4.82 (m, $\left.10 \mathrm{H}, \mathrm{CH}_{2} \mathrm{Ph}\right), 4.98(\mathrm{~s}, 1 \mathrm{H}, \mathrm{H}-1), 6.75$ (d, $2 \mathrm{H}, \mathrm{H}-3, \mathrm{H}-5$ on $\left.\mathrm{PhOCH}_{3}\right)$ 7.21-7.49 (m, $37 \mathrm{H}, \mathrm{Ar}-\mathrm{H}) .{ }^{13} \mathrm{C}$ NMR: 55.0, 63.7, 67.5, 71.8, 72.0, 72.2, 72.4, 72.6, 73.1, 78.1, 78.8, 81.7, 83.0, 86.3, 104.6, 112.9, 126.7, 127.3, 127.4, 127.5, 127.6, 127.7, 127.8, $127.9,128.0,128.1,128.2,128.4,130.4,135.6,137.0,138.1,138.3,138.5,138.6,144.5$, 158.3 .

2,5-Di-O-benzyl-3-0-(2-cyanoethyl $N, N$-diisopropylphosphoramidite)- $\beta$-ribofuranosyl 2,3,4-tri-0-benzyl-5-0-monomethoxy trityl-D-ribitol 43.

A solution of $11(1.721 \mathrm{~g}, 1.72 \mathrm{mmol})$ in $15 \mathrm{ml}$ dry THF was added to a solution of $\begin{array}{llllll}\text { diisopropylethylamine } & (1.2 \quad \mathrm{ml}, 6.87 \quad \mathrm{mmol}) & \text { and } & \text { 2-cyanoethyl }\end{array}$ $N, N$-diisopropylchlorophosphoramidilo $(0.74 \mathrm{ml}, 3.44 \mathrm{mmol})$ in $20 \mathrm{ml}$ THF at $\mathrm{tt}$. After stirring the solution for $24 \mathrm{~h}$, saturated sodium bicarbonate was added and the THF was evaporated. The residue was then extracted with ethyl acetate, washed with brine, dried $\left(\mathrm{Na}_{2} \mathrm{SO}_{4}\right)$ and concentrated. Purification on a short column eluting with 3:1:6 ether, triethylamine, hexanes gave the diasteromeric 43 as a white foam $(1.82 \mathrm{~g}, 88 \%)$. ${ }^{1} \mathrm{H}$ NMR (300 MHz): $1.05-1.17\left(\mathrm{~m}, 12 \mathrm{H}, 2 \mathrm{~N}\left(\mathrm{CH}_{3}\right)_{2}\right), 2.31-2.38\left(\mathrm{~m}, 2 \mathrm{H}, \mathrm{CH}_{2} \mathrm{CN}\right), 3.39-4.49(\mathrm{~m}, 17$ H), 3.75( $\left.\mathrm{s}, 3 \mathrm{H}, \mathrm{OCH}_{3}\right), 4.48-4.78\left(\mathrm{~m}, 10 \mathrm{H}, \mathrm{CH}_{2} \mathrm{Ph}\right), 4.97,4.98(2 \mathrm{~s}, 1 \mathrm{H}, \mathrm{H}-1), 6.74(\mathrm{~d}, 2$ $\mathrm{H}, \mathrm{H}-3, \mathrm{H}-5$ on $\mathrm{PhOCH}_{3}, \mathrm{~J}=8.9 \mathrm{~Hz}$ ), 7.08-7.48 (m, 37 H, Ar-H). ${ }^{13} \mathrm{C}$ NMR: 24.5, 24.6, $24.7,43.1,43.2,43.4,55.2,58.4,63.8,67.7,71.3,72.3,72.4,72.6,73.2,73.4,73.7,78.3$, 78.8, 78.9, 79.1, 81.5, 81.7, 86.4, 105.4, 105.6 (C-1), 113.0, 126.8, 127.4, 127.5, 127.6, $127.7,127.8,127.9,128.2,128.3,128.6,130.5,135.8,138.1,138.3,138.4,138.7,144.7$, 158.5. ${ }^{31}$ P NMR: 149.8 .

\section{2,5-Di-O-benzyl-3-0-levulinyl- $\beta$-ribofuranosyl 2,3,4-tri-0-benzyl-5-0-monomethoxy trityl-D-ribitol 44.}

A solution of DCC (0.792 $\mathrm{g}, 3.84 \mathrm{mmol})$ in $2 \mathrm{ml}$ THF was added to a solution of $\mathbf{4 2}$ 
(1.75 $\mathrm{g}, 1.75 \mathrm{mmol})$, DMAP $(0.373 \mathrm{~g}, 3.06 \mathrm{mmol})$ and levulinic acid $(0.31 \mathrm{ml}, 3.06 \mathrm{mmol})$ in $35 \mathrm{ml}$ of THF. After stirring for $24 \mathrm{~h}$, the solution was filtered through Celite washing with chloroform. After evaporation of the solvent, the residue was purified by short column chromatography eluting with $50 \%$ ether in hexanes affording 44 in quantitative yield. ${ }^{1} \mathbf{H}$ NMR (300 MHz) 2.13 (s, $3 \mathrm{H}, \mathrm{CH}_{3} \mathrm{CO}$ ), 2.63, 2.65 (2 d, $\left.4 \mathrm{H}, \mathrm{CH}_{2} \mathrm{CH}_{2}, \mathrm{~J}=5.31 \mathrm{~Hz}\right), 3.47$ (m, $2 \mathrm{H}, \mathrm{CH}_{2} \mathrm{OMMT}$ ), 3.48 (d, $2 \mathrm{H}, \mathrm{H}-5,5$ ', J = 4.9 Hz), $3.50(\mathrm{~m}, 1 \mathrm{H}), 3.75\left(\mathrm{~s}, 3 \mathrm{H}, \mathrm{OCH}_{3}\right)$, $3.87(\mathrm{~m}, 4 \mathrm{H}), 4.07$ (dd, $1 \mathrm{H}, \mathrm{H}-2, \mathrm{~J}_{1-2}=1.8 \mathrm{~Hz}, \mathrm{~J}_{2-3}=4.9 \mathrm{~Hz}$ ), $4.31(\mathrm{~m}, 1 \mathrm{H}, \mathrm{H}-4)$, 4.44-4.68 (m, $10 \mathrm{H}, \mathrm{CH}_{2} \mathrm{Ph}$ ), 4.98 (d, $1 \mathrm{H}, \mathrm{H}-1, \mathrm{~J}=1.9 \mathrm{~Hz}$ ), $5.13(\mathrm{t}, 1 \mathrm{H}, \mathrm{H}-3, \mathrm{~J}=5.2 \mathrm{~Hz}$ ), 6.74 (d, 2 H, H-3, H-5 on PhOCH 3 ), 7.20-7.48 (m, 37 H, Ar-H). ${ }^{13}$ C NMR: 24.5, 25.6, 27.8, $28.5,29.5,29.6,30.5,32.2,37.5,38.5,49.7,54.8,63.5,67.6,71.2,72.1,72.4,72.5,73.0$, 73.4, 73.6, 78.1, 78.5, 78.7, 79.9, 80.5, 86.1, 105.7 (C-1), 112.8, 126.5, 127.2, 127.3, 127.5, $127.6,127.9,128.0,128.1,128.3,130.2,125.5,137.5,137.9,138.2,138.4,144.4,158.2$, 171.8.

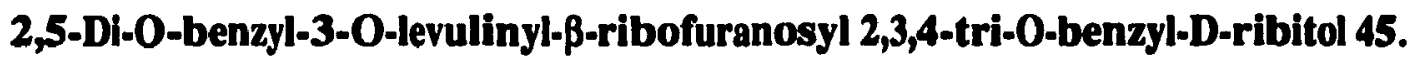

A solution of $44(1.921 \mathrm{~g})$ in $100 \mathrm{ml}$ of $3 \%$ trichloroacetic acid in methylene chloride was stirred at it for $1 \mathrm{~h}$. The solution was then poured in a saturated sodium bicarbonate solution $(100 \mathrm{ml})$, the aqueous layer was further extracted with methylene chloride $(2 \times 100 \mathrm{ml})$. After washing the combined extracts with brine and drying $\left(\mathrm{Na}_{2} \mathrm{SO}_{4}\right)$, the solution was concentrated and chromatographed (50\% ether in hexanes) yielding $1.23 \mathrm{~g}$ (85\%) of 45. $[\alpha]^{23}{ }_{\mathrm{D}} 1.65$, (c 1.09, $\left.\mathrm{CHCl}_{3}\right) .{ }^{1} \mathrm{H}$ NMR (300 MHz) $2.14\left(\mathrm{~s}, 3 \mathrm{H}, \mathrm{CH}_{3} \mathrm{CO}\right)$, 2.62, $2.66\left(2 \mathrm{~d}, 4 \mathrm{H}, \mathrm{CH}_{2} \mathrm{CH}_{2}, \mathrm{~J}=5.3 \mathrm{~Hz}\right.$ ), $3.53(\mathrm{~d}, 2 \mathrm{H}$, ribitol $\mathrm{H}-5,5$, J $=5.0 \mathrm{~Hz}$ ), 3.73-4.07 (m, 7 H, ribitol H), 4.10 (dd, $1 \mathrm{H}, \mathrm{H}-2^{\prime}, \mathrm{J}_{1^{\prime}-2^{\prime}}=2.2 \mathrm{~Hz}, \mathrm{~J}_{2^{\prime}-3^{\prime}}=5.1 \mathrm{~Hz}$ ), 4.33 (m, 1 $\left.\mathrm{H}, \mathrm{H}-4^{\prime}\right), 4.44-4.68$ (m, 10 H, $\mathrm{CH}_{2} \mathrm{Ph}$ ), 5.02 (d, $\left.1 \mathrm{H}, \mathrm{H}-1^{\prime}, \mathrm{J}=2.1 \mathrm{~Hz}\right), 5.17$ (t, $1 \mathrm{H}, \mathrm{H}-3^{\prime}, \mathrm{J}=$ 5.3 Hz), 7.27-7.3 (m, 25 H, ArH). ${ }^{13} \mathrm{C}$ NMR: 24.8, 26.2, 28.0, 29.8, 30.8, 32.5, 37.9, 61.4, $67.4,71.3,72.0,72.4,72.9,73.3,73.7,74.0,76.8,78.9,79.0,80.3,80.7,106.1$ (C-1), 
127.5-138.2 (Ar), $172.2(C O O)$.

\section{Dimer 46}

A solution of alcohol $45(1.501 \mathrm{~g}, 1.81 \mathrm{mmol})$ in $20 \mathrm{ml}$ dry acetonitrile was added to a solution of phosphoramidite $43(2.787 \mathrm{~g}, 2.32 \mathrm{mmol})$ and tetrazole $(1.624 \mathrm{mg}, 23.2 \mathrm{mmol})$ in $20 \mathrm{ml}$ acetonitrile at $\mathrm{rt}$. The solution was allowed to stir for $48 \mathrm{~h}$ by which time all of 45 was consumed. Pyridine ( $4 \mathrm{ml}$ ) was added followed by the addition of a $0.5 \mathrm{M}$ iodine solution in THF/water (2:1) until a red color persisted. The acetonitrile was then removed under vacuo and the residue taken in chloroform $(200 \mathrm{ml})$. This solution was then washed with saturated sodium bisulfite, brine, dried $\left(\mathrm{Na}_{2} \mathrm{SO}_{4}\right)$ and concentrated to dryness. Chromatography (40\% ethyl acetate in petroleum ether) afforded $3.335 \mathrm{~g}$ (95\%) of 46 as a white foam. ${ }^{1} \mathrm{H}$ NMR $(300 \mathrm{MHz}) 2.11\left(\mathrm{~s}, 3 \mathrm{H}, \mathrm{COCH}_{3}\right), 2.62\left(\mathrm{~m}, 4 \mathrm{H},-\mathrm{CH}_{2} \mathrm{CH}_{2}-\right), 3.38(\mathrm{~m}$, $2 \mathrm{H}$, ribose- $\left.\mathrm{CH}_{2}\right), 3.52\left(\mathrm{~m}, 2 \mathrm{H}\right.$, ribitol- $\left.\mathrm{CH}_{2}\right), 3.64(\mathrm{~m}, 1 \mathrm{H}), 3.72\left(\mathrm{~s}, 3 \mathrm{H}, \mathrm{OCH}_{3}\right), 3.34-5.06$ (m), 5.17 (t, $1 \mathrm{H}, \mathrm{H}-3^{\prime}$ ', J = 5.3 Hz), 6.74 (2 d, $2 \mathrm{H}, \mathrm{H}-3,5$ ' on $\left.\mathrm{PhOCH}_{3}\right)$, 7.22-7.50 (m, 62 H, Ar-H). $\quad{ }^{13} \mathrm{C}$ NMR 28.0, 29.8, 37.9, 55.2, 61.8, 61.9, 63.8, 67.3, 67.4, 68.1, 68.2, 70.7, 70.8, 71.3, 72.3, 72.4, 72.6, 73.3, 73.4, 73.6, 73.8, 77.3, 77.4, 77.8, 77.9, 78.3, 78.8, 78.9, $80.2,80.7,80.8,80.9,81.0,81.2,86.4,105.5,105.7,106.0$, (2 C-1), 113.0, 126.8, 127.2, $127.3,127.4,127.5,127.6,127.7,127.8,128.0,128.1,128.2,128.3,128.4,128.6,130.5$, $135.8,137.7,137.8,137.9,138.1,138.3,138.4,138.6,144.6,158.5,172.2$. ${ }^{31}$ P NMR -1.27, -1.65 .

Delevulination of dimer 46 giving 47

Levulinyl ester 46 was dissolved in $50 \mathrm{ml}$ of $0.5 \mathrm{M}$ hydrazine in pyridine-acetic acid (4:1) buffer and allowed to stir for $1 \mathrm{~h}$. 2,4-pentanedione $(3 \mathrm{ml})$ was then added and the mixture was dissolved in $500 \mathrm{ml}$ chloroform. The solution was then washed with saturated sodium bicarbonate $(2 \times 200 \mathrm{ml})$, saturated copper sulfate $(2 \times 200 \mathrm{ml})$ and finally with 
saturated ammonium chloride $(4 \times 200 \mathrm{ml})$. After drying and concentrating, the residue was chromatographed (40\% ethyl acetate in petroleum ether) yielding a pale blue oil. The oil was then redissolved in ethyl acetate and washed with saturated ammonium chloride (3X100 ml) thus eliminating most of the blue coloration. Chromatography using the same solvent system yielded 47 as a foam $(2.771 \mathrm{~g}, 87 \%)$. ${ }^{1} \mathrm{H}$ NMR $(300 \mathrm{MHz})$ (characteristic peaks only) absence of levulinyl proton signals, $2.56(\mathrm{~d}, 1 \mathrm{H}, \mathrm{OH}) .{ }^{31} \mathrm{P}$ NMR -1.29, -1.67 .

Fully deprotected tetrasaccharide 48.

$200 \mathrm{mg}$ of 47 was treated with $20 \mathrm{ml}$ of a $3 \%$ solution of trichloroacetic acid in methylene chloride for $30 \mathrm{~min}$. The red solution was washed with saturated sodium bicarbonate and the aqueous layer further extracted with chloroform. After drying and concentration to dryness, the residue was dissolved in $8 \mathrm{ml}$ of a ammonium hydroxide/methanol/THF (2.5/2.5/3) solution. and allowed to stir for $1 \mathrm{~h}$. The solvents were evaporated and the water removed as a benzene azeotrope. Short column chromatography eluting with 50\% ethyl acetate in petroleum ether then with $25 \%$ methanol in ethyl acetate yielded an oil. A solution of the oil in methanol $(20 \mathrm{ml})$ and water $(2 \mathrm{ml})$ was then shaken under hydrogen (40 psi) in the presence of $10 \% \mathrm{Pd} / \mathrm{C}(500 \mathrm{mg})$ for $6 \mathrm{~h}$. Filtration of the catalyst through Celite and evaporation of the methanol left an aqueous residue which was washed with methylene chloride $(2 \times 15 \mathrm{ml})$, ether $(15 \mathrm{ml})$ and pentane $(15 \mathrm{ml})$. The aqueous extract was then applied on a column of Dowex $X-8 \mathrm{Na}^{+}$ion exchange resin, slow elution with $150 \mathrm{ml}$ water followed by lyophilization gave $\mathbf{4 8}$ as a white powder (57 mg, 80\%). 'H NMR (300 MHz) 3.42-3.77 (m, $16 \mathrm{H}), 3.81$ (d, 1 H, H-2'), 3.81 (m, 1 H, H-3'), 4.00 (m, 1 H, H-4'), 4.09 (m, 2 H, H-2'", H-4'"), 4.42 (m, 1 H, H-3' ') $)$ 4.86, 4.88 (2 s, 2 H, 2 H-1). ${ }^{13} \mathrm{C}$ NMR 65.1, 65.3, 65.4, $69.6\left(\mathrm{~J}_{\mathrm{C}-\mathrm{P}}=5.0 \mathrm{~Hz}\right), 71.5$, 71.6, 73.1 (2 C), 73.5, 73.8, $\left(\mathrm{J}_{\mathrm{C}-\mathrm{P}}=7.6 \mathrm{~Hz}\right), 74.3,74.8,75.1,77.1,77.2,84.7\left(\mathrm{~J}_{\mathrm{C}-\mathrm{P}}=6.3\right.$ $\mathrm{Hz}), 85.6, \underline{109.6,109.8} 2 \mathrm{C}-1$. 31P NMR 0.68. HRMS (FAB, glycerol, $\mathrm{m} / \mathrm{z}$ ) for 
$\mathrm{C}_{20} \mathrm{H}_{39} \mathrm{O}_{20} \mathrm{PNa}\left(\mathrm{M}+\mathrm{H}^{+}\right)$, calcd 653.1670, found 6?, 1670

\section{Benzyl 2,3-0-benzylidene- $\beta$-D-ribofuranoside 52.}

To a solution of ribose $(5 \mathrm{~g})$ in $5 \mathrm{ml}$ dry DMF was added benzaldehyde dimethylacetal $(17 \mathrm{ml})$, dry benzyl alcohol $(17 \mathrm{ml})$ and camphorsulfonic acid $(3.9 \mathrm{~g})$. The mixture was stirred under vacuum (water aspirator, $10-15 \mathrm{~mm} \mathrm{Hg}$ ) for $24 \mathrm{~h}$. The reaction mixture was then dissolved in ether and washed with saturated sodium bicarbonate. After drying, $\left(\mathrm{MgSO}_{4}\right)$ the mixture was concentrated to an oil under high vacuum and with heating $\left(70-90^{\circ} \mathrm{C}\right)$. Chromatography $(1: 1$ ether/hexanes yielded an oil which was carefully recrystallised from cyclohexane yielding $52(4.37 \mathrm{~g}, 40 \%)$ as a white powder and as a mixture of exo and endo isomers. MP 49-50 ${ }^{\circ} \mathrm{C}$. ${ }^{1} \mathrm{H}$ NMR (200 MHz) 3.05, $3.21(2 \mathrm{dd}, 1 \mathrm{H}$, $\mathrm{OH}), 3.78$ (m, $\left.2 \mathrm{H}, \mathrm{H}-5,5^{\prime}\right), 4.63$ (m, $\left.1 \mathrm{H}, \mathrm{H}-4\right), 4.65,4.79$ (2 s, 2 H, $\left.\mathrm{CH}_{2} \mathrm{Ph}\right), 4.75,4.82$ (2 d, $1 \mathrm{H}, \mathrm{H}-3, \mathrm{~J}=6.3 \mathrm{~Hz}), 4.90,4.98(2 \mathrm{~d}, 1 \mathrm{H}, \mathrm{H}-2, \mathrm{~J}=6.4 \mathrm{~Hz}), 5.31,5.36(2 \mathrm{~s}, 1 \mathrm{H}, \mathrm{H}-1)$, 5.74, $5.98(2 \mathrm{~s}, 1 \mathrm{H}, \mathrm{CHPh}), 7.25-7.52(\mathrm{~m}, 10 \mathrm{H}, \mathrm{Ar}-\mathrm{H})$.

Benzyl 5-O-(2-cyanoethyl $N, N$-diisopropylphophoramidite)

2,3-0-benzylidene- $\beta$-D-ribofuranoside 53.

Phosphoramidite 53 was obtained as in the procedure for 43 using alcohol 52 (670 $\mathrm{mg})$, 2-O-cyanoethyl $N, N$-diisopropylchlorophosphoramidite $(0.91 \mathrm{ml})$ and diisopropylethylamine $(1.4 \mathrm{ml})$ in $20 \mathrm{ml}$ dry THF. Purification by chromatography (25\% ether, $1 \%$ triethylamine in hexanes) yielded the desired compound as an oil (87\%). ${ }^{31} \mathbf{P}$ NMR 139.5, 143.4. MS (CI, m/e, $\left.\mathrm{NH}_{3}, \%\right) 529\left(\mathrm{M}+\mathrm{H}^{+}, 100\right)$. HRMS (CI, $\left.\mathrm{NH}_{3}, \mathrm{~m} / \mathrm{e}\right)$ for $\mathrm{C}_{28} \mathrm{H}_{37} \mathrm{~N}_{2} \mathrm{O}_{6} \mathrm{P}$ calcd 529.24684 found 529.24675.

Reaction of 53 with alcohol 42 giving 59.

This compound was obtained in $88 \%$ from phosphoramidite $53(440 \mathrm{mg}, 0.83$ 
mmol), alcohol $43(522 \mathrm{mg}, 0.52 \mathrm{mmol}$ ) and tetrazole $(350 \mathrm{mg}, 5 \mathrm{mmol})$ as in the procedure for 46. ${ }^{31 P}$ NMR $-2.01,-2.09$.

\section{2-3-0-benzylidene-D-ribofuranoside 54.}

A suspension solution of ritose $(5 \mathrm{~g})$, anhydrous copper sulfate $(10 \mathrm{~g})$ benzaldehyde (4 eq, $15 \mathrm{ml})$ and camphorsulfonic acid $(0.5 \mathrm{eq}, 3.866 \mathrm{~g})$ in dry DMF was stirred at $\mathrm{rt}$ for 48 h. After neutralising the acid with concentrated ammonia $(30 \mathrm{ml})$, the mixture was then extracted with methylene chloride $(3 \times 100 \mathrm{ml})$ and the organic layer washed with saturated $\mathrm{NH}_{4} \mathrm{Cl}(3 \times 100 \mathrm{ml})$, dried $\left(\mathrm{Na}_{2} \mathrm{SO}_{4}\right)$ and concentrating to dryness. The oil was chromatographed (30\% EtAc in petroleum ether). Yield $3.4 \mathrm{~g}(42 \%)$. ${ }^{1} \mathrm{H}$ NMR $(200 \mathrm{MHz})$ 4.87 (m, 2 H, H-5, H-5'), 4.68 (m, 1 H, H-3), 4.79 (d, 1 H, H-3, J = 6 Hz), 4.97 (d, 1 H, H-2, $\mathrm{J}=6 \mathrm{~Hz}), 5.65(\mathrm{~s}, 1 \mathrm{H}, \mathrm{H}-1), 5.85(\mathrm{~s}, 1 \mathrm{H}, \mathrm{CH}-\mathrm{Ph}), 7.48-7.66(\mathrm{~m}, 5 \mathrm{H}, \mathrm{Ar}-\mathrm{H})$.

\section{5-O-Methoxytrityl 2-3-0-benzylidene-D-ribofuranoside 55.}

Monomethoxytrityl chloride $(5.839 \mathrm{~g}, 1.5 \mathrm{eq})$ was added to a solution of $54(3 \mathrm{~g})$, pyridine $(3.1 \mathrm{ml}, 3 \mathrm{eq})$ and DMAP $(0.769 \mathrm{~g}, 0.5 \mathrm{eq})$ in dry methylene chloride $(250 \mathrm{ml})$. After stirring for $12 \mathrm{~h}$ at $\mathrm{rt}$, the solution was poured in saturated sodium bicarbonate. The organic layer was then washed with brine, dried $\left(\mathrm{Na}_{2} \mathrm{SO}_{4}\right)$ and concentrated. Purification by chromatography (15\% ethyl acetate/petroleum ether) yielded $5.528 \mathrm{~g}(86 \%)$ of $55 .{ }^{1} \mathrm{H}$ NMR (200 MHz) $3.80\left(s, 3 \mathrm{H}, \mathrm{OCH}_{3}\right), 4.15(\mathrm{~d}, 1 \mathrm{H}, \mathrm{OH}, \mathrm{J}=9.9 \mathrm{~Hz}), 4.53(\mathrm{t}, 1 \mathrm{H}, \mathrm{H}-4, \mathrm{~J}=$

$3.24 \mathrm{~Hz}$ ), 4.80 (d, $1 \mathrm{H}, \mathrm{H}-3, \mathrm{~J}=6.2 \mathrm{~Hz}$ ), 4.95 (d, $1 \mathrm{H}, \mathrm{H}-2, \mathrm{~J}=6.0 \mathrm{~Hz}$ ), 5.48 (d, $1 \mathrm{H}, \mathrm{H}-1, \mathrm{~J}$ $=9.9 \mathrm{~Hz}), 5.81(\mathrm{~s}, 1 \mathrm{H}, \mathrm{CH}-\mathrm{Ph}), 6.86\left(\mathrm{~d}, 2 \mathrm{H}, \mathrm{H}-3, \mathrm{H}-5\right.$ on $\left.\mathrm{PhOCH}_{3}\right), 7.22-7.52(\mathrm{~m}, 19 \mathrm{H}$. Ar-H).

tert-Butyldimethylsilyl 5-0-Monomethoxytrityl-2-3-0-benzylidene-D-ribofuranoside 61. 
$(5.528 \mathrm{~g})$ and imidazole $(2.657 \mathrm{~g}, 3 \mathrm{eq})$ in dry DMF $(30 \mathrm{ml})$ at $\mathrm{rt}$. After completion of reaction $(6 \mathrm{~h})$, the solution was concentrated under vacuum to a syrup which was chromatographed (10\% ether in petroleum ether) yielding 61 as a mixture of anomers. $(6.717 \mathrm{~g}, 83 \%)$. Chromatography of an analytical sample afforded each anomer separately. ( $\alpha$-isomer) ${ }^{1} \mathrm{H}$ NMR $(200 \mathrm{MHz}) \quad 0.16,0.20\left(2 \mathrm{~s}, 6 \mathrm{H}, 2 \mathrm{CH}_{3}\right), 0.94\left(\mathrm{~s}, 9 \mathrm{H}, \mathrm{C}\left(\mathrm{CH}_{3}\right)_{3}\right), 3.09$ (dd, $1 \mathrm{H}, \mathrm{H}-5, \mathrm{~J}_{4-5}=3.7 \mathrm{~Hz}, \mathrm{~J}_{5-5^{\circ}}=10.0 \mathrm{~Hz}$ ), $3.37\left(\mathrm{dd}, 1 \mathrm{H}, \mathrm{H}-5^{\prime}\right), 3.80\left(\mathrm{~s}, 3 \mathrm{H}, \mathrm{OCH}_{3}\right), 4.44$ (m, $1 \mathrm{H}, \mathrm{H}-4), 4.68$ (dd, $1 \mathrm{H}, \mathrm{H}-3, \mathrm{~J}_{2-3}=7.1 \mathrm{~Hz}, \mathrm{~J}_{3-4}=2.3 \mathrm{~Hz}$ ), 4.78 (dd, $1 \mathrm{H}, \mathrm{H}-2, \mathrm{~J}_{1-2}=3.9$ $\mathrm{Hz}, \mathrm{J}_{2.3}=7.1 \mathrm{~Hz}$ ), 5.72 (d, $1 \mathrm{H}, \mathrm{H}-1, \mathrm{~J}=4.1 \mathrm{~Hz}$ ), 5.97 (s, $\left.1 \mathrm{H}, \mathrm{Ph}-\mathrm{CH}\right), 6.81-7.70$ (m, $19 \mathrm{H}$, Ar-H) (B-isomer) ${ }^{1} \mathrm{H}$ NMR (200 MHz) $-0.12,0.01\left(2 \mathrm{~s}, 6 \mathrm{H}, 2 \mathrm{CH}_{3}\right), 0.72(\mathrm{~s}, 9 \mathrm{H}$, $\left.\mathrm{C}\left(\mathrm{CH}_{3}\right)_{3}\right), 3.10\left(\mathrm{dd}, 1 \mathrm{H}, \mathrm{H}-5, \mathrm{~J}_{5-5^{\prime}}=9.2 \mathrm{~Hz}, \mathrm{~J}_{4-5}=10.2 \mathrm{~Hz}\right), 3.31\left(\mathrm{~d} \mathrm{~d}, 1 \mathrm{H}, \mathrm{H}-5^{\prime}, \mathrm{J}_{4-5^{\prime}}=4.8\right.$ $\mathrm{Hz}), 4.52\left(\mathrm{~d}, 1 \mathrm{H}, \mathrm{H}-3, \mathrm{~J}_{3.2}=6.2 \mathrm{~Hz}\right), 4.60\left(\mathrm{dd}, 1 \mathrm{H}, \mathrm{H}-4, \mathrm{~J}_{4.5}=10.2 \mathrm{~Hz}, \mathrm{~J}_{4.5}=4.8 \mathrm{~Hz}\right)$, $4.88\left(\mathrm{~d}, 1 \mathrm{H}, \mathrm{H}-2, \mathrm{~J}_{2-3}=6.1 \mathrm{~Hz}\right), 5.43(\mathrm{~s}, 1 \mathrm{H}, \mathrm{H}-1), 5.77(\mathrm{~s}, 1 \mathrm{H}, \mathrm{Ph}-\mathrm{CH}), 6.81-7.56(\mathrm{~m}, 19$ $\mathrm{H}, \mathrm{Ar}-\mathrm{H})$.

tert-Butyldimethylsilyl 2-3-0-benzylidene-D-ribofuranoside 62.

To a solution of $61(2.010 \mathrm{~g})$ in $100 \mathrm{ml}$ dry methylene chloride was added anhydrous trichloroacetic acid $(3 \mathrm{~g})$. After stirring for $30 \mathrm{~min}$, the acid was neutralised with $75 \mathrm{ml}$ saturated sodium bicarbonate solution. The organic phase was separated and the aqueous layer further extracted with methylene chloride. The combined extracts were then washed with brine, dried and concentrated to an oil. Purification by chromatography (5\% ether in toluene) yielded $2.523 \mathrm{~g}(67 \%)$ of the $\beta$-isomer and $617 \mathrm{mg}(17 \%)$ of the $\alpha$-isomer. Only the $\beta$-isomer was used in subsequent steps. $\left(\beta\right.$-isomer) $[\alpha]_{\mathrm{D}}{ }^{23}-44.58,\left(\mathrm{c} 1.13, \mathrm{CHCl}_{3}\right) .{ }^{1} \mathrm{H}$ NMR $(200 \mathrm{MHz}) 0.18\left(\mathrm{~s}, 6 \mathrm{H}, 2 \mathrm{CH}_{3}\right), 0.92\left(\mathrm{~s}, 9 \mathrm{H}, \mathrm{C}\left(\mathrm{CH}_{3}\right)_{3}\right), 3.58-3.75(\mathrm{~m}, 3 \mathrm{H}, \mathrm{H}-5,5$, $\mathrm{OH}), 4.59(\mathrm{~m}, 1 \mathrm{H}, \mathrm{H}-4), 4.64(\mathrm{~d}, 1 \mathrm{H}, \mathrm{H}-3, \mathrm{~J}=6.3 \mathrm{~Hz}), 4.97(\mathrm{~d}, 1 \mathrm{H}, \mathrm{H}-2, \mathrm{~J}=6.1 \mathrm{~Hz}), 5.54$ (s, $1 \mathrm{H}, \mathrm{H}-1)$, 5.75 (s, $1 \mathrm{H}, \mathrm{Ph}-\mathrm{CH}), 7.37-7.53$ (m, $5 \mathrm{H}, \mathrm{Ar}-\mathrm{H})$. ( $\left(\alpha\right.$-isomer) ${ }^{1} \mathrm{H}$ NMR (200 MHz) $0.17\left(\mathrm{~s}, 6 \mathrm{H}, 2 \mathrm{CH}_{3}\right), 0.95\left(\mathrm{~s}, 9 \mathrm{H}, \mathrm{C}\left(\mathrm{CH}_{3}\right)_{3}\right), 1.74(\mathrm{dd}, 1 \mathrm{H}, \mathrm{OH}), 3.81-4.14(\mathrm{~m}, 2 \mathrm{H}$, 
H-5,5'), 4.16 (dd, $1 \mathrm{H}, \mathrm{H}-4, \mathrm{~J}_{4-5}=3.9, \mathrm{~J}_{4-5}=7.1 \mathrm{~Hz}$ ), 4.73 (m, $\left.2 \mathrm{H}, \mathrm{H}-2,3\right), 5.48$ (d, $1 \mathrm{H}$, $\mathrm{H}-1, \mathrm{~J}_{1-2}=3.3 \mathrm{~Hz}$ ), 6.09 (s, $\left.1 \mathrm{H}, \mathrm{Ph}-\mathrm{CH}\right), 7.36-7.49$ (m, $\left.5 \mathrm{H}, \mathrm{Ar}-\mathrm{H}\right) . \mathrm{MS}$ (CI, m/e, NH,$\%$ ) $353\left(\mathrm{M}+\mathrm{H}^{+}\right), 295 \quad\left(\mathrm{M}^{+}-57, \quad 0.05\right), 238 \quad\left(\mathrm{M}+\mathrm{NH}_{4}{ }^{+}-\mathrm{HOSiMe}_{2} t-\mathrm{Bu}, \quad 0.21\right), 221$ $\left(\mathrm{M}+\mathrm{H}^{+}-\mathrm{HCSiMe}_{2} \mathrm{t}-\mathrm{Bu}, 100\right)$.

tert-Butyl dimethylsilyl 5-0-(2-cyanoethyl $N, N$-diisopropylphosphoramidite) 2,3-O-benzylidene- $\beta$-ribofuranoside 63 .

$62(1.018 \mathrm{~g})$ was phosphorylated according to the procedure for $43 \mathrm{using} 1.3 \mathrm{ml}(2$ eq) of 2-O-cyanoethyl $N, N$-diisopropylchlorophosphoramidite and $2.0 \mathrm{ml}(4 \mathrm{eq})$ of diisopropylethylamine in $60 \mathrm{ml}$ of THF. Purification by chromatography eluting with 20\% ether and $1 \%$ triethylamine in petroleum ether yielded 63 as a diastereomeric mixture. (1.230 g, 77\%). ${ }^{1} \mathrm{H}$ NMR (300 MHz) 0.11, 0.12, $0.13\left(3 \mathrm{~s}, 6 \mathrm{H}, 2 \mathrm{CH}_{3}\right), 0.89,090(2 \mathrm{~s}, 9 \mathrm{H}$, $\mathrm{SiC}\left(\mathrm{CH}_{3}\right)_{3}, 1.17-1.21\left(\mathrm{~m}, 12 \mathrm{H}, 2 \mathrm{NC}\left(\mathrm{CH}_{3}\right)_{2}\right), 2.62-2.66\left(\mathrm{~m}, 2 \mathrm{H}, \mathrm{CH}_{2} \mathrm{CN}\right), 3.58-3.88(\mathrm{~m}, 6$ H), 4.46 (m, 1 H, H-4), 4.64, 4.66 (2 d, 1 H, H-3, J = 6.2 Hz), 4.89, 4.91 (2 d, 1 H, H-2, J = 6 $\mathrm{Hz}$ ), 5.51, 5.52 (2 s, $1 \mathrm{H}, \mathrm{H}-1), 5.78$ (s, $1 \mathrm{H}, \mathrm{Ph}-\mathrm{CH})$, 7.37-7.53 (m, $5 \mathrm{H}, \mathrm{Ar}-\mathrm{H}) .{ }^{31} \mathrm{P}$ NMR 148.57, 148.76. Ms (CI, m/e, $\left.\mathrm{NH}_{3}, \%\right) 553\left(\mathrm{MH}^{+}, 0.48\right), 452\left(\mathrm{MH}^{+}-\mathrm{NiPr}_{2}, 100\right)$. HRMS (CI, $\left.\mathrm{NH}_{3}\right)$ for $\mathrm{C}_{27} \mathrm{H}_{46} \mathrm{~N}_{2} \mathrm{O}_{6} \mathrm{PSi}\left(\mathrm{MH}^{+}\right)$calcd. 553.28647 found 553.28613 .

\section{Dimer-phosphoramidite 58}

The delevulinated dimer $(572 \mathrm{mg}$ ) was phosphorylated according to the procedure for compound 43 using $0.22 \mathrm{ml}$ of diisopropylethylamine and $0.14 \mathrm{ml}$ 2-cyenoethyl $\mathrm{N}, \mathrm{N}$-diisopropylchlorophosphoramidite. After workup and chromatography using a solution of 1:1 ethyl acetate and petroleum ether containing $0.5 \mathrm{ml}$ triethylamine per $100 \mathrm{ml}$ using a high flow-rate, 58 was obtained in $91 \%$ yield. ${ }^{31}$ P NMR -1.77, $-1.35,149.8,150.0$. 


\section{General procedure for coupling reactions.}

Tetrazole (7-10 eq) was added to a flask containing the phosphoramidite $(1.3-1.8 \mathrm{eq})$ and a magnetic stirrer, the flask was then fitted with a septum and a short needle was inserted througk it. Another flask containing the alcohol ( 1 eq) was also fitted with the septum-needle arrangement. Both flasks were then placed in a dessicator and dried under vacuum over $\mathrm{P}_{2} \mathrm{O}_{5}$ for about $6 \mathrm{~h}$. The dessicator was then slowly filled with argon and the flasks removed. A solution of the alcohol in anhydrous acetonitrile $(0.05 \mathrm{M})$ was then added to the flask containing the phosphoramidite and the tetrazole. The solution was then stirred for 24-72 $\mathrm{h}$ at $\mathrm{rt}$. Dry pyridine (10-15 equ.) was then added followed by a $0.5 \mathrm{M}$ solution of iodine in THF/water (2:1) until the the brown color persisted. The solution was then concentrated under vacuum and the residue was dissolved in chloroform, this solution was then washed with saturated sodium thiosulfate, brine, dried $\left(\mathrm{Na}_{2} \mathrm{SO}_{4}\right)$ concentrated to dryness. The product was then purified by column chromatography.

General detritylation procedure for the oligomers.

A 3\% solution of dry trichloroacetic acid in methylene chloride was added to the tritylated compound to make a $0.02 \mathrm{M}$ solution and allowed to stir for about $30 \mathrm{~min}$. Saturated sodium bicarbonate was added and after separation of the phases, the aqueous layer was further extracted with chloroform. The combined extracts were then dried $\left(\mathrm{Na}_{2} \mathrm{SO}_{4}\right)$, concentrated to dryness and purified by chromatography to give the desired products in $80-90 \%$ yield.

\section{Monomer-spacer $64(n=1)$}

Starting from phosphoramidite $63(336 \mathrm{mg}, 0.61 \mathrm{mmol})$ and alcohol 43 (407 mg, $0.41 \mathrm{mmol}$ ) and tetrazole (199 $\mathrm{mg}, 2.84 \mathrm{mmol}$ ) the monomer was obtained in $85 \%$ yield (500 mg) as two diastereomers after purification by column chromatography (25\% ethyl acetate in petroleum ether). ${ }^{1} \mathrm{H} \mathrm{NMR}(300 \mathrm{MHz}) 0.09,0.11,0.12,0.13\left(4 \mathrm{~s}, 6 \mathrm{H}, \mathrm{Si}\left(\mathrm{CH}_{3}\right)_{2}\right)$, 
$0.88,0.89\left(9 \mathrm{H}, \mathrm{SiC}\left(\mathrm{CH}_{3}\right)_{3}\right), 2.31,2.40\left(2 \mathrm{t}, 2 \mathrm{H}, \mathrm{CH}_{2} \mathrm{CN}, \mathrm{J}=6.3 \mathrm{~Hz}\right), 3.41-4.12(\mathrm{~m}, 14 \mathrm{H})$, 3.75 (s, $3 \mathrm{H}$, , OCH $\left.), 4.29-4.79(\mathrm{~m}, 13 \mathrm{H}), 4.91(\mathrm{~m}, 1 \mathrm{H}, \mathrm{H}-3)^{\prime}\right), 4.97,5.04\left(2 \mathrm{~d}, 1 \mathrm{H}, \mathrm{H}-1^{\prime}, \mathrm{J}\right.$ $=2.4 \mathrm{~Hz}), 5.50,5.52\left(2 \mathrm{~s}, 1 \mathrm{H}, \mathrm{H}-\mathrm{1}^{\prime \prime}\right), 5.68,5.69(2 \mathrm{~s}, 1 \mathrm{H}, \mathrm{PhCH}), 6.74,6.74(2 \mathrm{~d}, 2 \mathrm{H}, \mathrm{H}-3$, 5 on PhOMe, J = 8.9 Hz), 7.08-7.50 (m, 44 H, Ar-H). ${ }^{13} \mathrm{C}$ NMR 17.9 (SiC), 19.1 (SiC),

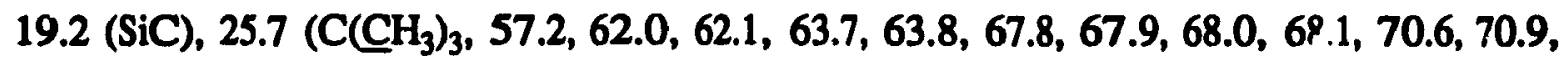
72.3, 72.7, 73.4, 73.7, 77.7, 78.3, 78.8, 78.9, 80.9, 81.1, 81.2, 82.4, 82.5, 84.5, 84.5, 86.4, 87.7, 102.9, 105.4, 10氵.5, 106.1, 113, 116.3, 126.7, 126.8, 127.0, 127.5, 127.6, 127.7, 127.8, $127.9,128.2,128.3,128.4,128.5,128.6,129.9,130.5,135.8,137.6,137.9,138.4,138.6$, 144.6, !44.1, 158.5. ${ }^{31}$ P NMR $-2.048,-2.204$.

\section{Dimer-spacer $64(n=2)$.}

The dimer was prepared in $89 \%$ yield from the dimer alcohol $47(1.665 \mathrm{~g}, 0.90$ mmol), phosphoramidite 63 (746 mg, $1.35 \mathrm{mmol})$ and tetrazole $(947 \mathrm{mg}, 13.5 \mathrm{mmol})$. The product was purified by column chromatography eluting with $50 \%$ ethyl acetate in petroleum ether. ${ }^{13} \mathrm{C}$ NMR 17.9, 18.9, 19.0, 19.1, 19.2, 19.3, $25.7\left(\mathrm{C}_{(\mathrm{CH}}\right)_{3}, 55.2,61.8$, $61.9,62.0,62.1,62.2,63.8,7.6,67.9,68.1,68.2,70.5,70.7,70.9,72.3,72.4,72.8,73.3$, 73.4, 73.7, 73.8, 76.8, 77.6, 77.8, 78.0, 78.8, 78.9, 80.8, 80.9, 81.0, 81.2, 81.3, 82.5, 84.4, $84.5,86.5,87.7,103.0,105.6,106.2,113.1,116.4,116.5,126.7,126.8,127.0,127.5,127.6$, 127.8, 128.0, 128.2, 128.3, 128.4, 128.6, 130.0, 135.8, 135.9, 137.5, 137.6, 137.9, 138.0, 138.2, 138.5, 138.6, 138.7, 144.7, 158.5. ${ }^{31}$ P NMR -1.34, -1.76, 1, 7, -2.19.

Trimer-spacer $64(n=3)$.

Reaction of the detritylated monomer $65(\mathrm{n}=1)(159 \mathrm{mg}, 0.13 \mathrm{mmol})$ with the phosphoramidite $58(408 \mathrm{mg}, 0.20 \mathrm{mmol})$ in the presence of tetrazole $(93 \mathrm{mg}, 1.33 \mathrm{mmol}$ ) provided the trimer in $74 \%$ yield after column chromatography $(50 \%$ ethyl acetate in petroleum ether). ${ }^{13} \mathrm{C}$ NMR 17.9, 18.8, 18.9, 19.0, 19.1, 19.2, 25.6, 55.2, 61.7, 61.8, 61.9, 
$62.1,63.7,63.8,67.4,67.5,67.6,67.8,67.9,68.0,68.1,68.2,70.5,70.7,70.8,72.2,72.6$, 73.3, 73.4, 73.7, 73.8, 76.4, 76.5, 76.7, 76.8, 76.9, 77.1, 77.3, 77.9, 78.3, 78.7, 78.9, 80.8, $80.9,81.2,81.3,81.3,81.5,82.4,82.5,84.3,84.5,86.4,87.7,102.9,105.5,105.6,105.7$, $105.8,106.1,113.0,116.3,116.4,126.7,126.8,126.9,127.1,127.3$, 127.4, 127.5, 127.6, $127.7,127.8,127.9,128.2,128.3,128.4,128.5,129.9,130.5,135.7,137.4,137.5,137.6$, 137.8, 137.9, 138.1, 138.2, 138.03, 138.4, 138.6, 144.6, 144.7, 158.4. $\quad{ }^{31}$ P NMR -1.24, $-1.28,-1.62,-1.70,-1.89,-2.12$.

Tetramer-spacer $64(n=4)$.

Tetrazole ( $265 \mathrm{mg}, 3.79 \mathrm{mmol}$ ) catalyzed reaction of the detritylated dimer $65(\mathrm{n}=$ 2) (430 $\mathrm{mg}, 0.21 \mathrm{mmol}$ ) with the phosphoramidite $58(776 \mathrm{mg}, 0.38 \mathrm{mmol})$ afforded the tetramer in $78 \%$ yield after purification by chromatography (50\% ethyl acetate in petroleum ether then ethyl acetate). ${ }^{13} \mathrm{C}$ NMR 18.8, 18.9, 19.0, 19.1, 25.6, 55.1, 61.7, 61.9, 62.0, 62.1, $63.6,63.7,67.4,67.7,67.8,67.9,68.0,68.1,70.4,70.6,70.8$, , 72.2, 72.7, 73.2, 73.3, 73.6, 73.7, 76.6, 73.7, 76.6, 76.7, 77.1, 77.2, 77.3, 78.8, 78.2, 78.7, 78.8, 80.8, 80.9, 81.1, 81.4, $81.5,82.3,82.4,84.3,87.6,102.8,105.4,105.5,105.6,105.7,1057,106.1,112.9,116.3$, $126.7,126.9,127.4,127.5,127.6,127.9,128.1,128.2,128.3,128.5,129.8,130.4,135.7$, $137.4,137.5,137.7,137.8,138.0,138.1,138.2,138.3,138.5,138.6,144.5,144.6,158.4$. ${ }^{31}$ P NMR $-1.31,-1.68,-1.76,-1.96,-2.18$

Pentamer-spacer $64(n=1)$.

A mixture of the detritylated trimer $65(\mathrm{n}=3)(155 \mathrm{mg}, 0.05 \mathrm{mmol})$, phosphoramidite $58(198 \mathrm{mg}, 0.10 \mathrm{mmol})$ and tetrazole $(68 \mathrm{mg}, 0.97 \mathrm{mmol})$ in acetonitrile was stirred at $\mathrm{it}$ for $72 \mathrm{~h}$. The product was then purified by column chromatography eluting with $50 \%$ ether in toluene then $50 \%$ ethyl acetate in toluene yielding $233 \mathrm{mg}(89 \%)$ of the pentamer. ${ }^{13} \mathrm{C}$ NMR 18.9, 19.0, 19.1, 25.6, 55.2, 61.8, 61.9, 63.7, 63.8, 67.5, 67.6, 68.1, 
70.5, 70.7, 70.8, 72.2, 72.3, 72.6, 73.3, 73.4, 73.7, 73.8, 76.6, 77.3, 77.9, 78.3, 78.7, 78.9, 80.8, 80.9, 81.2, 81.5, 81.6, 82.5, 86.3, 87.7, 102.9, 105.5, 105.7, 105.8, 106.1, 113.0, $116.5,126.8,126.9,127.5,127.6,127.7,127.9,128.2,128.3,128.4,128.5,128.7,128.9$, $130.5,135.7,137.4,137.5,137.8,137.9,138.1,138.2,138.3,138.4,138.6,144.6,158.6$. ${ }^{31}$ P NMR -1.30, $-1.67,-1.75,-1.84,-1.95,-2.18,-2.81$

\section{General deprotection procedures.}

\section{Decyanoethylation and debenzylation.}

The detritylated compound was dissolved in a solution of methanol-concentrated ammonium hydroxide (7:3) (THF was sometimes added to aid dissolution) and stirred at it for $18 \mathrm{~h}$. The solution was concentrated to dryness using benzene to co-evaporate the water. After purification by preparative TLC (5-20\% methanol in toluene and developing twice, the product was eluted from the silica gel scrapings with 1:1 ethyl acetate and methanol) the resulting oil was dissolved in methanol $(10-20 \mathrm{ml})$ and water (3-6) $\mathrm{ml}$ and $10 \% \mathrm{Pd} / \mathrm{C}(\sim 500 \mathrm{mg})$ was added. The mixture was then shaken under hydrogen at $45 \mathrm{psi}$ for $12 \mathrm{~h}$. The catalyst was filtered through Celite and the filter cake washed with methanol and water. After evaporation of the methanol, the residue was then diluted to about $5 \mathrm{ml}$ with water and the solution washed with methylene chloride $(2 \times 15 \mathrm{ml})$, ether (1X15 ml) and pentane $(1 \times 15 \mathrm{ml})$. The aqueous solution was then applied to a $50 \mathrm{ml}$ burette packcd with about $50 \mathrm{~cm}$ of Dowex X-8 resin $\mathrm{Na}^{+}$form and eluted (1 drop per second) with $100 \mathrm{ml}$ of water. Lyophilization gave the silylated polysaccharide as a white powder in 75-90\% yields.

Monomer-spacer $66(n=1)$.

${ }^{1} \mathrm{H}$ NMR $(300 \mathrm{MHz}) 0.00\left(\mathrm{~s}, 6 \mathrm{H}, \mathrm{Si}\left(\mathrm{CH}_{3}\right)_{2}\right), 0.73\left(\mathrm{~s}, 9 \mathrm{H}, \mathrm{C}\left(\mathrm{CH}_{3}\right)_{3}\right), 3.46-4.12(16$ H), 4.43 (m, $\left.1 \mathrm{H}, \mathrm{H}-3^{\prime}\right), 4.87$ (s, $\left.1 \mathrm{H}, \mathrm{H}-1^{\prime}\right), 5.13$ (s, $1 \mathrm{H}$, spacer H-1). ${ }^{13} \mathrm{C}$ NMR 20.1 
(SiC), $27.9\left(\mathrm{CH}_{3}\right), 65.1,65.2,69.8\left(\mathrm{~J}_{\mathrm{C}-\mathrm{P}}=4.2 \mathrm{~Hz}\right), 71.6,73.1,73.7,74.8,75.0,76.6\left(\mathrm{~J}_{\mathrm{C}-\mathrm{p}}=\right.$ 3.4 Hz), $77.1\left(\mathrm{~J}_{\mathrm{C}-\mathrm{P}}=5.4 \mathrm{~Hz}\right), 78.7,83.6\left(\mathrm{~J}_{\mathrm{C}-\mathrm{P}}=8.5 \mathrm{~Hz}\right), 84.7\left(\mathrm{~J}_{\mathrm{C}-\mathrm{P}}=6.3 \mathrm{~Hz}\right), 105.1$ (spacer C-1), 109.5 (C-1) ${ }^{31}$ P NMR 0.16. MS (FAB, glycerol, m/e) $455\left(\mathrm{M}+\mathrm{Na}^{+}, 100\right)$

Dimer-spacer $66(n=2)$.

${ }^{1} \mathrm{H}$ NMR $(300 \mathrm{MHz})-0.01,0.00\left(2 \mathrm{~s}, 6 \mathrm{H}, \mathrm{Si}\left(\mathrm{CH}_{3}\right)_{2}\right), 0.73\left(\mathrm{~s}, 9 \mathrm{H}, \mathrm{C}\left(\mathrm{CH}_{3}\right)_{3}\right)$, 3.45-4.11 (m, $27 \mathrm{H}), 4.42$ (m, $\left.2 \mathrm{H}, 2 \mathrm{H}-3^{\prime}\right), 4.87$ (s, $\left.2 \mathrm{H}, 2 \mathrm{H}-1^{\prime}\right), 5.13$ (s, $1 \mathrm{H}$, spacer H-1'). ${ }^{13} \mathrm{C}$ NMR 20.1, 27.9, 65.1, 65.2, 65.2, $69.6\left(\mathrm{~J}_{\mathrm{C}-\mathrm{P}}=5.2 \mathrm{~Hz}\right), 69.8 .71 .6,73.1,73.7,73.8,74.3$, 74.8, 75.0, 76.6, 77.1, 77.1, 78.7, 83.7 (J $\mathrm{J}_{\mathrm{C}-\mathrm{P}}=8.6 \mathrm{~Hz}$ ), 84.7, 84.8, 84.8, 105.1 (spacer C-1), 109.5, 109.6 (2 C.1). ${ }^{31}$ P NMR 0.09 (1 P), 0.61(1 P). MS (FAB, glycerol, m/e) 1023 $\left(\mathrm{M}+\mathrm{Na}^{+}\right)$

Trimer-spacer $66(n=3)$.

${ }^{1} \mathrm{H} \mathrm{NMR}(300 \mathrm{MHz}) 0.00\left(\mathrm{~s}, 6 \mathrm{H}, \mathrm{Si}\left(\mathrm{CH}_{3}\right)_{2}\right), 0.73\left(\mathrm{~s}, 9 \mathrm{H}, \mathrm{C}\left(\mathrm{CH}_{3}\right)_{3}\right), 3.45-4.13(\mathrm{~m}$, $38 \mathrm{H}$ ), 4.40-44 (m, $\left.3 \mathrm{H}, 3 \mathrm{H}-3^{\prime}\right), 4.87$ (s, $\left.3 \mathrm{H}, 3 \mathrm{H}-1^{\prime}\right), 5.13$ (s, $1 \mathrm{H}$, spacer H-1). ${ }^{13} \mathrm{C}$ NMR: $20.127 .9,65.1,65.1,65.2,69.5\left(\mathrm{~J}_{\mathrm{C}-\mathrm{P}}=4.2 \mathrm{~Hz}\right), 69.8\left(\mathrm{~J}_{\mathrm{C}-\mathrm{P}}=5.8 \mathrm{~Hz}\right), 71.5,1.6,72.9,73.0$, 73.7, 73.8, 74.3, 74.8, 75.0, 76.6, 77.0, 77.1, 78.7, $83.6\left(\mathrm{~J}_{\mathrm{C}-\mathrm{P}}=8.5 \mathrm{~Hz}\right), 84.6,84.7,84.8$, 105.1 (spacer C-1), 109.5 (3 C-1). ${ }^{31}$ P NMR: 0.16 (1 P), 0.68 (2 P). MS (FAB, glycerol, $\mathrm{m} / \mathrm{e}) 1369\left(\mathrm{MH}^{+}\right), 1391\left(\mathrm{M}+\mathrm{Na}^{+}\right)$.

Tetramer-spacer $66(n=4)$.

${ }^{1} \mathrm{H} \mathrm{NMR}(300 \mathrm{MHz})-0.10\left(\mathrm{~s}, 6 \mathrm{H}, \mathrm{Si}\left(\mathrm{CH}_{3}\right)_{2}\right), 0.73\left(\mathrm{~s}, 9 \mathrm{H}, \mathrm{C}\left(\mathrm{CH}_{3}\right)_{3}\right), 3.45-4.40(\mathrm{~m}$, $49 \mathrm{H}$ ), 4.42-4.63 (m, $\left.4 \mathrm{H}, 4 \mathrm{H}-3^{\prime}\right), 4.87$ (s, $\left.4 \mathrm{H}, 4 \mathrm{H}-1^{\prime}\right), 5.13$ (s, $1 \mathrm{H}$, spacer $\left.\mathrm{H}-1\right)$. ${ }^{13} \mathrm{C}$ NMR: $20.1,27.9,65.2,69.5,69.7,71.5,73.0,73.6,73.8,74.3,74.7,75.0,76.4,76.6,77.0$, 77.1, 77.2, 78.7, 83.6 (J $\left.\mathrm{J}_{\mathrm{C}-\mathrm{P}}=8.2 \mathrm{~Hz}\right), 84.6,84.8\left(\mathrm{~J}_{\mathrm{C}-\mathrm{P}}=6.1 \mathrm{~Hz}\right), 105.1$ (spacer C-1), $109.5(4$ C-1) ${ }^{31}$ P NMR: 0.19 (1 P), 0.72 (3 P). 
Pentamer-spacer $66(n=5)$.

${ }^{1} \mathrm{H}$ NMR $(300 \mathrm{MHz})-0.01,0.00\left(2 \mathrm{~s}, 6 \mathrm{H}, \mathrm{Si}\left(\mathrm{CH}_{3}\right)_{2}\right), 0.73\left(\mathrm{~s}, 9 \mathrm{H}, \mathrm{C}\left(\mathrm{CH}_{3}\right)_{3}\right)$, 3.45-4.08 (m, $60 \mathrm{H}), 4.40-4.46(\mathrm{~m}, 5 \mathrm{H}, 5 \mathrm{H}-3$ '), 4.88 (s, $5 \mathrm{H}, 5 \mathrm{H}-1), 5.13$ (s, $1 \mathrm{H}$, spacer H-1). ${ }^{13}$ C NMR: $20.1,27.8,65.0,65.1,69.4,69.5,59.6,71.4,71.5,72.9,73.6,73.7,74.2$, 74.7, 75.0, 76.5, 77.0, 77.1, 78.7, 83.6 (J $\left.\mathrm{J}_{-\mathrm{P}}=8.5 \mathrm{~Hz}\right), 84.6,84.7\left(\mathrm{~J}_{\mathrm{C}-\mathrm{P}}=6.2 \mathrm{~Hz}\right), 105.1$ (spacer C-1), 109.5 (5 C-1). ${ }^{31}$ P NMR: 0.17 (1 P), 0.70 (4 P)

\section{Desilylation.}

A $1.0 \mathrm{M}$ potassium hydrogen fluoride aqueous solution buffered with pyridine $(\mathrm{pH}$ 5-6) (3 eq) was added to a solution of the silylated oligomer in water (3-5 ml) and stimed at $\mathrm{rt}$ for $12 \mathrm{~h}$. This reaction was performed in a polypropylene container. The solution was then washed with methylene chloride $(2 \times 15 \mathrm{ml})$, ether $(1 \mathrm{X} 15 \mathrm{ml})$ and pentane $(1 \times 15 \mathrm{ml})$. The fully deprotected oligomer was then purified by elution with water (1 drop per second, $100 \mathrm{ml}$ ) through a burette packed with Dowex $\mathrm{X}-8$ resin $\mathrm{Na}^{+}$form. Lyophilization yielded a white powder which gave a positive Benedict's test. Yields obtained were almost quantitative.

Monomer-spacer $67(n=1)$.

$$
[\alpha]^{23} \mathrm{D}-4.94\left(\mathrm{c} 2.22, \mathrm{H}_{2} \mathrm{O}\right) \text {. }{ }^{1} \mathrm{H} \text { NMR (300 MHz) 3.43-4.13 (m, 16 H), 4.39-4.46 (m, }
$$
$\left.1 \mathrm{H}, \mathrm{H}-3^{\prime}\right), 4.87(\mathrm{~s}, 1 \mathrm{H}, \mathrm{H}-1), 5.06\left(\mathrm{~d}, \beta-\mathrm{H}_{-}^{\mathrm{r}}-1, \mathrm{~J}=2.1 \mathrm{~Hz}\right), 5.21(\mathrm{~d}, \alpha-\mathrm{H}-1, \mathrm{~J}=3.9 \mathrm{~Hz}),{ }^{13} \mathrm{C}$ NMR: 65.2, $68.2\left(\mathrm{~J}_{\mathrm{C} . \mathrm{p}}=5.2 \mathrm{~Hz}\right), 68.6\left(\mathrm{~J}_{\mathrm{C}-\mathrm{P}}=5.3 \mathrm{~Hz}\right), 71.5,72.8,73.0,73.1,73.2,73.5$, 74.7. 75.0, 76.5, $77.1\left(\mathrm{~J}_{\mathrm{C}-\mathrm{P}}=4.8 \mathrm{~Hz}\right), 77.9,83.8\left(\mathrm{~J}_{\mathrm{C}-\mathrm{P}}=8.5 \mathrm{~Hz}\right), 84.6,84.7,99.2(\alpha-\mathrm{C}-1)$, 103.9 ( $\beta-C-1), 109.5$ (C-1) 31P NMR: 0.21. MS (FAB, glycerol, $\mathrm{m} / \mathrm{z}) 519\left(\mathrm{MH}^{+}\right), 541$ $\left(\mathrm{M}+\mathrm{Na}^{+}\right)$. HRMS (FAB, diethanolamine) for $\mathrm{C}_{15} \mathrm{H}_{29} \mathrm{O}_{16} \mathrm{PNa}\left(\mathrm{M}+\mathrm{H}^{+}\right)$calcd 519.10616, found 519.10909; for $\mathrm{C}_{15} \mathrm{H}_{28} \mathrm{O}_{16} \mathrm{PNa}_{2}\left(\mathrm{M}+\mathrm{Na}^{+}\right)$calcd 541.09093, found 541.091038. 
Dimer-spacer $67(n=2)$.

$[\alpha]^{23}{ }_{D}-7.50\left(c 0.14, \mathrm{H}_{2} \mathrm{O}\right) .{ }^{1} \mathrm{H}$ NMR (300 MHz) 3.43-4.11 (27 H), 4.39-4.43 (m, 2 H, 2 H-3'), 4.87 (s, 2 H, 2 H-1'), 5.06 (d, $\beta-H-1, J=1.8$ Hz), 5.22 (d, $\alpha-H-1, J=3.9$ Hz). ${ }^{13} \mathrm{C}$ NMR: 65.2, 65.3, 65.5, 69.2, $69.7\left(\mathrm{~J}_{\mathrm{C}-\mathrm{P}}=4.2\right), 71.1,73.0,73.1,73.2,73.3,73.6,73.9$, 74.0, 74.4, 74.5, 74.9, 75.0, 75.1, 76.7, 77.3, 78.1, 83.9 (J $\left.\mathrm{J}_{\mathrm{C}-\mathrm{P}}=7.1 \mathrm{~Hz}\right), 84.9\left(\mathrm{~J}_{\mathrm{C}-\mathrm{P}}=5.3 \mathrm{~Hz}\right)$, 99.3 ( $\alpha$-C-1), 104.1 ( $\beta-C-1), 109.7$ (2 C-1). ${ }^{31}$ P NMR: 0.25 (1 P), 0.71 (1 P). MS (FAB, glycerol, $\mathrm{m} / \mathrm{z}) 887\left(\mathrm{M}+\mathrm{H}^{+}\right)$.

Trimer-spacer $67(n=3)$.

$[\alpha]^{23}{ }_{D}-10.39\left(\mathrm{c} \mathrm{0.16,} \mathrm{H}_{2} \mathrm{O}\right) .{ }^{1} \mathrm{H}$ NMR $(300 \mathrm{MHz}) 3.37-4.10(38 \mathrm{H}), 4.38-4.45(\mathrm{~m}$, 3 H, $\left.3 \mathrm{H}-3^{\prime}\right), 4.87$ (s, $\left.3 \mathrm{H}, 3 \mathrm{H}-1^{\prime}\right), 5.07$ (s, $\left.\beta-\mathrm{H}-1\right), 5.21$ (d, $\alpha-\mathrm{H}-1, \mathrm{~J}=3.9 \mathrm{~Hz}$ ). ${ }^{13} \mathrm{C}$ NMR: $65.2,65.3,65.4,69.2,69.5,69.6,71.6,72.9,73.0,73.1,73.2,73.2,73.6,73.7,73.8,74.3$, 74.8, 74.9, 75.1, 76.5, 77.1, 77.2, 78.0, 83.8, 83.9, 84.7, 84.8, 84.9, $99.2(\alpha-C-1), 104.0$ ( $\beta-C-1), 109.6\left(3 \mathrm{C}-1^{\prime}\right){ }^{31}$ P NMR: 0.15 (1 P ), 0.62 (2 P).

Tetramer-spacer $67(n=4)$.

$[\alpha]^{23}{ }_{\mathrm{D}}-15.16,\left(\mathrm{c} \mathrm{0.74}, \mathrm{H}_{2} \mathrm{O}\right) .{ }^{1} \mathrm{H}$ NMR (300 MHz) 3.43-4.11 (49 H), 4.35-4.45 (m, 4 H, 4 H-3'), 4.85 (S, 4 H, 4 H-1'), 5.06 (d, $\beta-H-1, J=1.8$ Hz), 5.21 (d, $\alpha-H-1, J=3.9$ Hz). ${ }^{13} \mathrm{C}$ NMR 65.2, 65.4, $69.1\left(\mathrm{~J}_{\mathrm{C}-\mathrm{P}}=5.8 \mathrm{~Hz}\right), 69.6\left(\mathrm{~J}_{\mathrm{C}-\mathrm{P}}=5.3 \mathrm{~Hz}\right), 71.5,72.9,73.1,73.2,73.5$, $73.8\left(\mathrm{~J}_{\mathrm{C}-\mathrm{P}}=7.8 \mathrm{~Hz}\right), 74.3,74.8,75.0,76.6,76.9,77.1,77.2,77.3,77.9,83.9,84.7,84.8$, 84.9, $99.2(\alpha-C-1), 104.0$ ( $\beta-C-1), 109.6$ (4 C-1') ${ }^{31}$ P NMR: 0.23 (1 P), 0.70 (3 P).

Pentamer-spacer $67(n=5)$.

$[\alpha]^{23} \mathrm{D}-13.15,\left(\mathrm{c} 0.43, \mathrm{H}_{2} \mathrm{O}\right) .{ }^{1} \mathrm{H}$ NMR $(300 \mathrm{MHz}) 3.42-4.13(60 \mathrm{H}), 4.38-4.46(\mathrm{~m}, 5$ H, 5 H-3'), 4.87 (s, 5 H, 5 H-1'), 5.07 (d, $\beta-H-1, J=1.8 \mathrm{~Hz}$ ), $5.22(d, \alpha-H-1, J=3.9 \mathrm{~Hz}$ ). 
$\left.{ }^{13} \mathrm{C} \mathrm{NMR:} \mathrm{65.2,} \mathrm{65.3,} \mathrm{69.5} \mathrm{(J} \mathrm{J}_{\mathrm{C}-\mathrm{P}}=5.0 \mathrm{~Hz}\right), 71.5,71.7,71.8,73.0,73.2,73.6,73.7\left(\mathrm{~J}_{\mathrm{C}-\mathrm{P}}=7.8\right.$ $\mathrm{Hz}), 74.3,74.8,75.0,76.6,77.0,77.1,77.9,84.7,84.8,99.2(\alpha-C-1), 104.0(\beta-C-1), 109.5$ (5 C-1'). 31P NMR: 0.19 (1 P), 0.66 (4 P).

\section{Chapter 3}

3, 5-0-benzylidene-D-ribonic acid $\boldsymbol{\gamma}$-lactone 71.

71 was prepared according to the procedure of Chen and Jouille ${ }^{63}$. A mixture of D-ribonolactone 70 , benzaldehyde $(80 \mathrm{ml})$ and concentrated hydrochloric acid $(8 \mathrm{ml})$ was vigorously stirred overnight. Ether $(100 \mathrm{ml})$ was then added and the white precipitate collected and washed successively with ether, saturated sodium bicarbonate and water. The solid was dried and used without purification. An analytical sample was recrystallised from acetone-petroleum ether, $\mathrm{mp} 230-231^{\circ} \mathrm{C}$ (lit $230-231^{\circ} \mathrm{C}$ ).

3, 5-0-benzylidene 2-0-(1-methyl-1-methoxy ethyl)-D-ribonic acid $\gamma$-lactone 72.

Pyridinium p-toluenesulfonate ( $117 \mathrm{mg}, 0.02 \mathrm{eq}$ ) was added to an ice-cold solution of $71(5.5 \mathrm{~g})$ and 2-methoxypropene $(3.3 \mathrm{ml}, 1.5 \mathrm{eq})$ in dry DMF $(50 \mathrm{ml})$. After stirring overnight the solution was poured in $500 \mathrm{ml}$ water and the white precipitate collected by filtration (Yield 5.6g, 78\%). The compound was used without purification in the following step. ' ${ }^{\mathrm{H}} \mathrm{NMR}(200 \mathrm{MHz}) 1.47,1.49\left(2 \mathrm{~s}, 6 \mathrm{H}, 2 \mathrm{CH}_{3}\right), 3.32\left(\mathrm{~s}, 3 \mathrm{H}, \mathrm{OCH}_{3}\right), 4.30$, (dd, $1 \mathrm{H}$, $\left.\mathrm{H}-3, \mathrm{~J}_{3-4}=1.8 \mathrm{~Hz}, \mathrm{~J}_{2-3}=13.3 \mathrm{~Hz}\right), 4.52\left(\mathrm{~d}, 1 \mathrm{H}, \mathrm{H}-2, \mathrm{~J}_{2-3}=12.1 \mathrm{~Hz}\right), 4.56(\mathrm{~d}, 1 \mathrm{H}, \mathrm{H}-4, \mathrm{~J}=$ $2.7 \mathrm{~Hz}$ ), 4.63 (d, $1 \mathrm{H}, \mathrm{H}-5, \mathrm{~J}=8.1 \mathrm{~Hz}), 4.75$, (dd, $1 \mathrm{H}, \mathrm{H}-5^{\prime}, \mathrm{J}_{5.5^{\circ}}=7.9 \mathrm{~Hz}, \mathrm{~J}_{4.5^{\circ}}=3.0 \mathrm{~Hz}$ ), 5.76 (s, $1 \mathrm{H}, \mathrm{CHPh})$, 7.3-7.5 (m, $5 \mathrm{H}, \mathrm{Ar}-\mathrm{H}) . \mathrm{MS}\left(\mathrm{CI}, \mathrm{NH}_{3}, \mathrm{~m} / \mathrm{e}, \%\right) 277\left(\mathrm{MH}^{+}-\mathrm{MeOH}, 7.1\right)$, $235\left(\mathrm{MH}^{+}-\mathrm{MeOH}-\left(\mathrm{CH}_{3}\right)_{2} \mathrm{C}, 38.0\right), 130(100)$ 


\section{3, 5-0-benzylidene 2-0-(1-methyl-1-methoxy ethyl)-D-ribitol 73}

Lithium aluminum hydride $(1.23 \mathrm{~g}, 2 \mathrm{eq})$ was added to a solution of $72(5 \mathrm{~g})$ in 200 $\mathrm{ml}$ dry THF. After $5 \mathrm{~h}$, the reaction was quenched successively with $1.23 \mathrm{ml}$ water, $1.23 \mathrm{ml}$ $15 \%$ sodium hydroxide andfinally with $3.69 \mathrm{ml}$ water. The resulting precipitate was filtered and washed with ethyl acetate. Evaporation of the solvents gave an oil which was without purification used in the next step (Yield 90\%). ${ }^{1} \mathrm{H}$ NMR (200 MHz) 1.43, 1.53 (2 s, $\left.6 \mathrm{H}, 2 \mathrm{CH}_{3}\right), 3.34\left(\mathrm{~s}, 3 \mathrm{H}, \mathrm{OCH}_{3}\right), 2.30(\mathrm{t}, 1 \mathrm{H}, 1-\mathrm{OH}, \mathrm{J}=6.8 \mathrm{~Hz}), 3.58-3.68(\mathrm{~m}, 1 \mathrm{H}$, H-4), 3.79-3.85 (m, 3 H, H-1, 1', H-3), 3.91-4.00 (m, 2 H, H-3, 4-OH), 4.09-4.22 (m, 2 H, H-5, 5'), 4.31-4.36 (m, $1 \mathrm{H}, \mathrm{H}-2), 5.80$ (s, $1 \mathrm{H}, \mathrm{CHPh}), 7.36-7.50$ (m, $5 \mathrm{H}, \mathrm{Ar}-\mathrm{H})$.

\section{1, 4-Di-0-benzyl 3,5-0-benzylidene 2-0-(1-methyl-1-methoxy ethyl)-D-ribitol 74}

73 was benzylated as for 22 yielding 74 in $85 \%$ yield after chromatography (10\% ethyl acetate in hexanes). ${ }^{1} \mathrm{H}$ NMR (200 MHz) 1.27, $1.32\left(2 \mathrm{~s}, 6 \mathrm{H}, \mathrm{CH}_{3}\right), 3.22(\mathrm{~s}, 3 \mathrm{H}$, $\left.\mathrm{OCH}_{3}\right), 3.56-3.76(\mathrm{~m}, 2 \mathrm{H}), 3.78,3.87(\mathrm{~m}, 2 \mathrm{H}), 4.09-4.11(\mathrm{~m}, 1 \mathrm{H}), 4.46-4.66(4 \mathrm{H}, \mathrm{H}-2$ and $\left.2 \mathrm{CH}_{2} \mathrm{Ph}\right), 5.82(\mathrm{~s}, 1 \mathrm{H}, \mathrm{CHPh}), 7.27-7.49(\mathrm{~m}, 15 \mathrm{H}, \mathrm{ArH})$.

\section{1, 4-Di-O-benzyl 3, 5-0-benzylidene-D-ribitol 75.}

A solution of $74(1 \mathrm{~g})$ in $15 \mathrm{ml}$ THF and $15 \mathrm{ml} 20 \%$ aqueous acetic acid was stirred for $1 \mathrm{~h}$. The acid was neutralised with solid sodium carbonate. THF was removed and the mixture was extracted into ethyl acetate. After drying $\left(\mathrm{Na}_{2} \mathrm{SO}_{4}\right)$ and concentration, the compound was purified by chromatography (ethyl acetate in hexanes) yielding 75 in quantitative yields. $[\alpha]^{23}{ }_{\mathrm{D}}-142.46,\left(\mathrm{c} 1.00, \mathrm{CHCl}_{3}\right) .{ }^{1} \mathrm{H} \mathrm{NMR}(200 \mathrm{MHz}) 3.54(\mathrm{~d}, 1 \mathrm{H}$, $\mathrm{OH}, \mathrm{J}=3.8 \mathrm{~Hz}$ ), 3.61-3.70 (m, 2 H, H-1, H-5), 3.76-3.89 (m, 2 H, H-1', H-5'), 4.01-4.06 (m, $1 \mathrm{H}, \mathrm{H}-2$ ), 4.25 (dd, $1 \mathrm{H}, \mathrm{H}-3$ ), 4.50-4.56 (m, $1 \mathrm{H}, \mathrm{H}-4$ ), 4.60, 4.61 (2 s, $4 \mathrm{H}, 2 \mathrm{CH}_{2} \mathrm{Ph}$ ), 5.78 (s, $1 \mathrm{H}, \mathrm{CHPh})$, 7.27-7.43 (m, 15 H, Ar-H). 
2'-0-Acetyl-3'-0-allyl-5'-0-benzyl- $\beta$-D-ribofuranosyl 2,5-di-0-benzyl

\section{3,4-0-benzylidene-L-ribitol 76}

76 was obtained in $74 \%$ yield by the reaction of ribitol 75 with orthoester 27 using the procedure for ribosyl-ribitol 40. ${ }^{1} \mathrm{H}$ NMR $(300 \mathrm{MHz}) 2.10\left(\mathrm{~s}, 3 \mathrm{H}, \mathrm{COCH}_{3}\right), 3.56(\mathrm{dd}, 1 \mathrm{H})$, 3.67 (dd, $1 \mathrm{H}), 3.81-4.19$ (m, $13 \mathrm{H}), 4.56-4.66\left(\mathrm{~m}, 6 \mathrm{H}, 3 \mathrm{CH}_{2} \mathrm{Ph}\right.$ ), 5.11 (dd, $1 \mathrm{H}, \mathrm{H}-2, \mathrm{~J}=$ 1.0, 4.6 Hz), 5.19 (s, $1 \mathrm{H}, \mathrm{H}-1), 5.21-5.26\left(\mathrm{~m}, 2 \mathrm{H}\right.$, vinylic $\left.\mathrm{CH}_{2}\right), 5.81-5.90(\mathrm{~m}, 1 \mathrm{H}$, vinylic CH), 7.27-7.58 (m, 15 H, Ar-H). ${ }^{13} \mathrm{C}$ NMR 20.8, 69.2, 69.5, 70.4, 70.5, 71.3, 71.9, 73.1, $73.2,73.3,73.4,74.8,76.7,80.1,80.2,80.3,80.4,100.8,106.9,117.7,126.5,127.4,127.5$, $127.6,127.7,128.2,128.3,128.4,128.5,128.9,134.1,137.7,138.1,138.3,138.8,170.0$.

3'-0-allyl-5'-0-benzyl- $\beta$-D-ribofuranosyl 2,5-di-O-benzyl 3,4 -0-benzylidene-L-ribitol 76a.

A solution of $76(700 \mathrm{mg})$ and sodium methoxide $(26 \mathrm{mg})$ in methanol was stirred at rt for 2 h. After evaporation of methanol under vacuum, the residue was dissolved in methylene chloride $(150 \mathrm{ml})$ and the solution washed with brine. After drying and evaporation of the solvent, the residue was chromatographed hexanes/ethyl acetate (3:1) giving a quantitative yields of 76a. ${ }^{1} \mathrm{H}$ NMR $(200 \mathrm{MHz}) 2.51(\mathrm{~d}, 1 \mathrm{H}, \mathrm{OH}, \mathrm{J}=5.4 \mathrm{~Hz})$, 3.49 (d, $2 \mathrm{H}, \mathrm{H}-5, \mathrm{~J}=5.0 \mathrm{~Hz}$ ), 3.79-4.14 (m, $14 \mathrm{H}), 4.50-4.70\left(\mathrm{~m}, 6 \mathrm{H}, 3 \mathrm{CH}_{2} \mathrm{Ph}\right.$ ), 5.02 (d, 1 $\mathrm{H}, \mathrm{H}-1, \mathrm{~J}=2.4 \mathrm{~Hz}$ ), 5.20-5.32 (m, $2 \mathrm{H}$, vinylic $\mathrm{CH}_{2}$ ), 5.53 (s, $\left.1 \mathrm{H}, \mathrm{CHPh}\right), 5.82-5.95$ (m, 1 $\mathrm{H}$, vinylic $\mathrm{CH})$, 7.23-7.55 (m, $20 \mathrm{H}, \mathrm{Ar}-\mathrm{H})$.

\section{3'-0-allyl-5'-0-benzyl- $\beta$-D-ribofuranosyl 2,5-di-O-benzyl-L-ribitol 77.}

A solution of $76 \mathrm{a}(29 \mathrm{mg})$ in a $10 \mathrm{ml}$ trifluoroacetic acid/THF/water (2:2:1) was stirred for $3 \mathrm{~h}$ at $\mathrm{rt}$. The reaction was then neutralised with solid sodium carbonate and the mixture was then extracted with chloroform $(3 \times 75 \mathrm{ml})$. The combined extracts were washed with brine, dried $\left(\mathrm{Na}_{2} \mathrm{SO}_{4}\right)$ and concentrated to dryness. Chromatography gave triol 
77 in 78\%. $[\alpha]_{\mathrm{D}^{23}}+4.84^{\circ},\left(\mathrm{c} 4.05, \mathrm{CHCl}_{3}\right)$. ${ }^{1} \mathrm{H}$ NMR $(200 \mathrm{MHz}) 2.45(\mathrm{~d}, 1 \mathrm{H}, \mathrm{OH}, \mathrm{J}=3.6$ $\mathrm{Hz}$ ), 3.3.02 (d, $1 \mathrm{H}, \mathrm{OH}, \mathrm{J}=5.5 \mathrm{~Hz}$ ), 3.39 (dd, $1 \mathrm{H}), 3.49-4.12(\mathrm{~m}, 15 \mathrm{H}), 3.80$ (d, $1 \mathrm{H}, \mathrm{OH}$, $\mathrm{J}=9.5 \mathrm{~Hz}), 4.41-4.61\left(\mathrm{~m}, 6 \mathrm{H}, 3 \mathrm{CH}_{2} \mathrm{Ph}\right), 4.95(\mathrm{~d}, 1 \mathrm{H}, \mathrm{H}-1, \mathrm{~J}=1.2 \mathrm{~Hz}), 5.18-5.31(\mathrm{~m}, 2 \mathrm{H}$, vinylic $\left.\mathrm{CH}_{2}\right), 5.78-5.91(\mathrm{~m}, 1 \mathrm{H}$, vinylic $\mathrm{CH}), 7.268-7.35(\mathrm{~m}, 15 \mathrm{H}, \mathrm{Ar}-\mathrm{H})$.

\section{Chapter 4}

\section{1,5:2,3-Di-0-benzylidene- $\beta$-D-ribofuranoside 78.}

A solution of ribose $(2 \mathrm{~g})$, benzaldehyde dimethyl acetal $(8 \mathrm{ml}, 4 \mathrm{eq})$ and camphorsulfonic acid $(1.55 \mathrm{~g}, 0.5 \mathrm{eq})$ in DMF $(5 \mathrm{ml})$ was stirred under water aspirator vacuum for $24 \mathrm{~h}$ at $\mathrm{rt}$. The solution was then poured in saturated sodium bicarbonate and extracted with $3 \times 100 \mathrm{ml}$ methylene chloride. After washing the combined extracts with water (200 ml), drying $\left(\mathrm{Na}_{2} \mathrm{SO}_{4}\right)$ and concentrating under vacuum (water aspirator and then high vacuum), the residue was chromatographed (15\% ethyl acetate in hexanes) to give a white solid. Recrystallisation from cyclohexane gave white needles. $(2.37 \mathrm{~g}, 54 \%)$. MP 109-110 ${ }^{\circ} \mathrm{C} .[\alpha]^{23} \mathrm{D}-3.37,\left(\mathrm{c} 1.21, \mathrm{CHCl}_{3}\right.$ ). ${ }^{1} \mathrm{H}$ NMR (200 MHz) 3.83 (dd, $1 \mathrm{H}, \mathrm{H}-5, \mathrm{~J}_{4-5}=$ $2.3 \mathrm{~Hz}$ ), 4.09 (d, $1 \mathrm{H}, \mathrm{H}-5^{\prime}, \mathrm{J}_{5-5^{\prime}}=12.6 \mathrm{~Hz}$ ), 4.81-4.89 (m, $3 \mathrm{H}, \mathrm{H}-2, \mathrm{H}-3$ and $\left.\mathrm{H}-4\right), 5.79$, 5.80, 5.81 (3 s, 3 H, H-1, 2 CHPh), 7.35-7.57 (m, 10 H, Ar-H). ${ }^{13} \mathrm{C}$ NMR 72.0, 82.7, 88.2, 88.3, 100.9 (C-1), 105.3, $\underline{105.9}$ (2 Ph-CH), 126.0, 127.0, 128.46, 128.5, 128.9, 129.9, 135.9, 138.5. Anal. calcd for $\mathrm{C}_{19} \mathrm{H}_{18} \mathrm{O}_{5} \mathrm{C}, 69.93 ; \mathrm{H}, 5.52 ; \mathrm{O}, 24.55$. Found $\mathrm{C}, 69.90 ; \mathrm{H}, 5.39 ; \mathrm{O}$, 24.71.

5-0-Benzyl-2,3-0-benzylidene- $\beta$-D-ribofuranoside 80.

To an ice-cold suspension solution of $78(920 \mathrm{mg}, 2.82 \mathrm{mmol})$, sodium cyanoborohydride ( $1.778 \mathrm{~g}, 28.2 \mathrm{mmol}$ ) and $3 \mathrm{~A}$ molecular sieves $(8 \mathrm{~g})$ in $80 \mathrm{ml}$ anhydrous 
acetonitrile was added a solution trimethylsilyl chloride $(3.58 \mathrm{ml}, 28.2 \mathrm{mmol})$ in $20 \mathrm{ml}$ acetonitrile. After stirring for $8 \mathrm{~h}$ at $0^{\circ} \mathrm{C}$, the reaction was quenched with $10 \%$ sodium carbonate $(60 \mathrm{ml})$. The reaction mixture was then filtered through Celite and the acetonitrile removed under vacuum. The residue was then extracted into methylene chloride. After washing the organic layer with brine, drying $\left(\mathrm{Na}_{2} \mathrm{SO}_{4}\right)$ and concentrating, the residue was purified by chromatography eluting with $30 \%$ ether in hexanes yielding $\mathbf{8 0}$ as a white solid. (445 mg, 48\%). MP (ethyl acetate/hexanes) $70-71^{\circ} \mathrm{C} .[\alpha]^{23}{ }_{\mathrm{D}} 0.35$, (c 1.08, $\mathrm{CHCl}_{3}$ ). ${ }^{1} \mathrm{H}$ NMR (200 MHz) 3.64 (dd, $1 \mathrm{H}, \mathrm{H}-5, \mathrm{~J}_{4,5}=2.3 \mathrm{~Hz}, \mathrm{~J}_{5.5}=10.2 \mathrm{~Hz}$ ), 3.72 (dd, $\left.1 \mathrm{H}, \mathrm{H}-5^{\prime}, \mathrm{J}_{4-5^{\prime}}=2.4 \mathrm{~Hz}\right), 4.56(\mathrm{br} \mathrm{t}, 1 \mathrm{H}, \mathrm{H}-4, \mathrm{~J}=2.0 \mathrm{~Hz}$ ), .61 (d, $1 \mathrm{H}, \mathrm{H}-3, \mathrm{~J}=6.5$ $\mathrm{Hz}$ ), 4.62 (dd, $2 \mathrm{H}, \mathrm{Ph}-\mathrm{CH}_{2}, \mathrm{~J}=11.6 \mathrm{~Hz}$ ), $4.76(\mathrm{~d}, 1 \mathrm{H}, \mathrm{OH}, \mathrm{J}=11.9 \mathrm{~Hz}$ ), 4.83 (d, $1 \mathrm{H}, \mathrm{H}-2$, $\mathrm{J}=6.4 \mathrm{~Hz}), 5.44(\mathrm{~d}, 1 \mathrm{H}, \mathrm{H}-1, \mathrm{~J}=11.9 \mathrm{~Hz}), 5.75(\mathrm{~s}, 1 \mathrm{H}, \mathrm{Ph}-\mathrm{CH}), 7.29-7.51(\mathrm{~m}, 10 \mathrm{H}$, Ar-H). ${ }^{13}$ C NMR $70.9,73.8,82.7,85.0,87.8,103.2,105.6,126.8,127.9,128.2,128.3$, 129.7, 135.7, 136.0. Anal. calcd for $\mathrm{C}_{19} \mathrm{H}_{20} \mathrm{O}_{5} ; \mathrm{H}, 69.50 ; \mathrm{H}, 6.10 ; \mathrm{O}, 24.40$. Found $\mathrm{C}$, $69.24 ; \mathrm{H}, 6.32 ; \mathrm{O}, 24.44$. 52 was also obtained in $8 \%$ yield

\section{1,5:2,3-Di-O-(4-methoxybenzylidene)-B-D-ribofuranoside 79}

To a solution of 4-methoxybenzaldehyde dimethyl acetal $(55 \mathrm{~g}, 3 \mathrm{eq})$ and ribose (15 $\mathrm{g})$ in $15 \mathrm{ml}$ dry DMF was added a mixture of camphorsulfonic acid $(2.32 \mathrm{~g}, 0.1 \mathrm{eq})$ and pyridine $(0.8 \mathrm{ml}, 0.1 \mathrm{eq})$. The solution was then stirred at $\mathrm{rt}$ under vacuum (water aspirator) for $24 \mathrm{~h}$. DMF was removed under vacuum and the mixture was chromatographed, eluting with toluene. The residue obtained was then recrystallised from cyclohexane yielding the desired compound as white needles $(19.6 \mathrm{~g}, 50 \%)$. MP $129^{\circ} \mathrm{C}$. $[\alpha]^{23} \mathrm{D}-7.02$, (c 1.04, $\mathrm{CHCl}_{3}$ ). ${ }^{1} \mathrm{H}$ NMR (200 MHz) 3.80, 3.81 (2 s, $\left.6 \mathrm{H}, 2 \mathrm{OCH}_{3}\right), 3.78-3.85(\mathrm{~m}, 1 \mathrm{H}, \mathrm{H}-5), 4.07$ (d, $1 \mathrm{H}, \mathrm{H}-5$ ', J = 12.5 Hz), 4.79-4.81 (m, $3 \mathrm{H}, \mathrm{H}-2, \mathrm{H}-3$ and H-4), 5.74, 5.75, $5.76(3 \mathrm{~s}, 3 \mathrm{H}$, $\mathrm{H}-1$ and $2 \mathrm{Ph}-\mathrm{CH}), 6.90,6.92\left(2 \mathrm{~d}, 4 \mathrm{H}\right.$, aromatic $\mathrm{H}-3$ and $\left.\mathrm{H}-5 \mathrm{I}^{\prime}=8.8 \mathrm{~Hz}\right), 7.40,7.45(2 \mathrm{~d}$, $4 \mathrm{HI}$, aromatic $\mathrm{H}-2$ and $\mathrm{H}-6, \mathrm{~J}=8.8 \mathrm{~Hz}) .{ }^{13} \mathrm{C}$ NMR $71.9,82.6,88.2,100.8(\mathrm{C}-1), 105.3$, 
105.8 (2 Ph-CH), 113.7, 113.9, 114.3, 127.2, 127.9, 128.0, 128.4, 130.9, 132.0. MS (CI, $\left.\mathrm{NH}_{3}, \mathrm{~m} / \mathrm{z}, \%\right) 387\left(\mathrm{M}+\mathrm{H}^{+}, 100\right), 251\left(\mathrm{MH}^{+}-136,97\right)$.

\section{2,3-0-(4-methoxybenzylidene)-5-0-(4-methoxybenzyl)- $\beta$-D-ribofuranoside 81}

This compound could be obtained in $70 \%$ yield using the same procedure as for compound 80 , however the reaction was ran at $-40^{\circ} \mathrm{C}$ and was complete in $2 \mathrm{~h} .[\alpha]^{23}{ }_{\mathrm{D}} 7.98$, (c 1.96, $\left.\mathrm{CHCl}_{3}\right) .{ }^{1} \mathrm{H}$ NMR (200 MHz) 3.62, $3.69\left(2 \mathrm{dd}, 2 \mathrm{H}, \mathrm{H}-5\right.$ and $\mathrm{H}-5^{\prime}, \mathrm{J}_{5-5^{\prime}}=10.2 \mathrm{~Hz}$, $\left.\mathrm{J}_{4-5}=2.3 \mathrm{~Hz}, \mathrm{~J}_{4-5^{\circ}}=2.0 \mathrm{~Hz}\right), 3.82,3.83\left(2 \mathrm{~s}, 6 \mathrm{H}, 2 \mathrm{OCH}_{3}\right), 4.48-4.64(\mathrm{~m}, 4 \mathrm{H}, \mathrm{H}-3, \mathrm{H}-4$ and $\left.\mathrm{CH}_{2} \mathrm{Ph}\right), 4.79$ (d, $1 \mathrm{H}, \mathrm{H}-2, \mathrm{~J}=6.4 \mathrm{~Hz}$ ), 4.86 (d, $1 \mathrm{H}, \mathrm{OH}, \mathrm{J}=12.1 \mathrm{~Hz}$ ), 5.44 (d, $1 \mathrm{H}, \mathrm{H}-1, \mathrm{~J}$ $=12.0 \mathrm{~Hz}), 5.69(\mathrm{~s}, 1 \mathrm{H}, \mathrm{Ph}-\mathrm{CH}), 6.91-6.93(2 \mathrm{~d}, 4 \mathrm{H}$, aromatic $\mathrm{H}-3$ and $\mathrm{H}-5, \mathrm{~J}=8.8 \mathrm{~Hz})$, 7.26, 7.43 ( $2 \mathrm{~d}, 4 \mathrm{H}$, aromatic $\mathrm{H}-2$ and $\mathrm{H}-6, \mathrm{~J}=8.8 \mathrm{~Hz}$ ). ${ }^{13} \mathrm{C}$ NMR 70.7, 73.8, 82.7, 85.3, 88.0, 103.5 (C-1), 105.7 (Ph-C), 113.8, 113.9, 114.1, 114.2, 128.0, 128.1, 128.3, 128.4, 129.9, 159.8, 160.8. $\mathrm{MS}\left(\mathrm{CI}, \mathrm{NH}_{3}, \mathrm{~m} / \mathrm{z}, \%\right) 389\left(\mathrm{M}+\mathrm{H}^{+}, 61\right), 371\left(\mathrm{MH}^{+}-\mathrm{H}_{2} \mathrm{O}, 20\right)$.

Chloro 5-O-(4-methoxybenzyl) 2,3-O-(4-methoxybenzylidene)- $\beta$-D-ribofuranoside 82. Methanesulfonyl chloride $(0.25 \mathrm{ml}, 2.32 \mathrm{mmol})$ was added to a solution of 81 (451 $\mathrm{mg}, 1.16 \mathrm{mmol})$, triethylamine $(0.49 \mathrm{ml}, 3.49 \mathrm{mmol})$ and tetraethylammonium chloride (192 $\mathrm{mg}, 1.16 \mathrm{mmol})$ in dry methylene chloride $(25 \mathrm{ml})$ at $0^{\circ} \mathrm{C}$. The solution was allowed to warm to $\mathrm{rt}$ and stirred for $4 \mathrm{~h}$. TLC at this point showed almost no starting material. The solvent was removed and the residue purified by chromatography (25\% ethyl acetate/hexanes) yielding 82 (445 mg, 94\%). ${ }^{1} \mathrm{H}$ NMR (200 MHz) 3.71 (d, $2 \mathrm{H}, \mathrm{H}-5$ and H-5', J = 7.2 Hz), $3.81\left(\mathrm{~s}, 6 \mathrm{H}, 2 \mathrm{OCH}_{3}\right), 4.53\left(\mathrm{~s}, 2 \mathrm{H}, \mathrm{CH}_{2} \mathrm{Ph}\right), 4.67$ (t, $1 \mathrm{H}, \mathrm{H}-4, \mathrm{~J}=7.23$ Hz), 4.87 (d, $1 \mathrm{H}, \mathrm{H}-3, \mathrm{~J}=6.0 \mathrm{~Hz}$ ), 5.07 (d, $1 \mathrm{H}, \mathrm{H}-2, \mathrm{~J}=6.0 \mathrm{~Hz}$ ), 5.79 (s, $1 \mathrm{H}, \mathrm{CHPh}), 6.27$ (s, $1 \mathrm{H}, \mathrm{H}-1), 6.88,6.89$ (2 d, $4 \mathrm{H}$, aromatic $\mathrm{H}-3$ and $\mathrm{H}-5, \mathrm{~J}=8.6 \mathrm{~Hz}), 7.28,7.39$ (2 d, $4 \mathrm{H}$, aromatic $\mathrm{H}-2$ and $\mathrm{H}-4, \mathrm{~J}=8.6 \mathrm{~Hz}$ ) 


\section{(4-penten-1-yl) 5-0-(methoxybenzyl)}

\section{2,3-0-(4-methoxybenzylidene)-B-D-ribofuranoside 83.}

Methanesulfonyl chloride $(0.03 \mathrm{ml}, 0.30 \mathrm{mmol})$ was added to an ice-cold solution of 81 (105 $\mathrm{mg}, 0.27 \mathrm{mmol})$, triethylamine $(0.8 \mathrm{ml}, 0.54 \mathrm{mmol}$ ) and tetra-n-butylammonium bromide $(436 \mathrm{mg}, 1.35 \mathrm{mmol}$ ) in methylene chloride $(5 \mathrm{ml})$. The reaction mixture was allowed to warm to $\mathrm{rt}$ and after $2 \mathrm{~h}$ TLC showed absence of 81 and of 82. 4-Penten-1-0l $(0.08 \mathrm{ml}, 1.35 \mathrm{mmol})$ was then added and the reaction allowed to proceed overnight. The mixture was diluted with $20 \mathrm{ml}$ methylene chloride and this solution was washed with saturated sodium bicarbonate and brine. After drying and chromatography, 83 was isolated in $40 \%$ yield as a mixture of exo and endo isomers. ${ }^{1} \mathrm{H}$ NMR $(200 \mathrm{MHz}) 1.58-1.68(\mathrm{~m}, 2 \mathrm{H}$, H-2 of pentenyl group), 2.069 (q, $2 \mathrm{H}, \mathrm{H}-3$ of pentenyl group, $\mathrm{J}=6.6 \mathrm{~Hz}$ ), 3.328-3.49, 3.60-3.68 ( $2 \mathrm{~m}, 2 \mathrm{H}, \mathrm{H}-1$ of pentenyl group), 3.51-3.52 (m, $2 \mathrm{H}, \mathrm{H}-5$ and H-5'), 3.80 (s, $6 \mathrm{H}$, $\left.\mathrm{OCH}_{3}\right), 4.45-4.55(\mathrm{~m}, 1 \mathrm{H}, \mathrm{H}-4), 4.49$ (s, $\left.2 \mathrm{H}, \mathrm{CH}_{2} \mathrm{Ph}\right), 4.63-4.66$ (m, $\left.1 \mathrm{H}, \mathrm{H}-3\right), 4.74,4.83$ (2 d, $1 \mathrm{H}, \mathrm{H}-2, \mathrm{~J}=6.4 \mathrm{~Hz}), 4.94-5.07\left(\mathrm{~m}, 2 \mathrm{H}\right.$, vinylic $\left.\mathrm{CH}_{2}\right), 5.14,5.18(2 \mathrm{~s}, \mathrm{H}-1), 5.73-5.86$ ( $\mathrm{m}, 1 \mathrm{H}$, vinylic $\mathrm{CH}), 5.74,5.91(2 \mathrm{~s}, 1 \mathrm{H}, \mathrm{CH}-\mathrm{Ph}), 6.87,6.89(2 \mathrm{~d}, 4 \mathrm{H}$, aromatic $\mathrm{H}-3$ and $\mathrm{H}-5, \mathrm{~J}=8.8 \mathrm{~Hz}), 7.26,7.41(2 \mathrm{~d}, 4 \mathrm{H}$, aromatic $\mathrm{H}-2$ and $\mathrm{H}-4, \mathrm{~J}=8.7 \mathrm{~Hz}) . \mathrm{MS}\left(\mathrm{Cl}, \mathrm{NH}_{3}\right.$, $\mathrm{m} / \mathrm{z}, \%) 457\left(\mathrm{MH}^{+}, 16\right)$.

\section{Appendix}

3-0-Benzyl-1,2:5,6-di-O-isopropylidene- $\alpha$-D-glucofuranose 86.

86 was prepared according to the procedure of Czernecki ${ }^{35}$ and used without purification in the following step. 


\section{3-0-Benzyl-1,2-0-isopropylidene- $\alpha$-D-glucofuranose 87.}

A solution of 86 in $100 \mathrm{ml}$ of $70 \%$ aqueous acetic acid was stirred at $40^{\circ} \mathrm{C}$ for $24 \mathrm{~h}$. The reaction mixture was cooled and quenched with solid sodium carbonate until basic. The mixture was then extracted into methylene chloride. After drying and concentrating to dryness, 87 was obtained as an oil $(18 \mathrm{~g}, 95 \%)$. ${ }^{1} \mathrm{H}$ NMR $(200 \mathrm{MHz}) 1.32,1.48(2 \mathrm{~s}, 6 \mathrm{H}$, $2 \mathrm{CH}_{3}$ ), 2.12, 2.54 (2 br s, $2 \mathrm{H}, 2 \mathrm{OH}$ ), 3.59-3.93 (m, $2 \mathrm{H}, \mathrm{H}-6$ and H-6'), 3.95-4.25 (m, 3 H), 4.63 (d, $1 \mathrm{H}, \mathrm{H}-2, \mathrm{~J}=3.8 \mathrm{~Hz}$ ), $4.63\left(\mathrm{dd}, 2 \mathrm{H}, \mathrm{CH}_{2} \mathrm{Ph}, \mathrm{J}=11.7 \mathrm{~Hz}\right.$ ), $5.93(\mathrm{~d}, 1 \mathrm{H}, \mathrm{H}-1, \mathrm{~J}=$ $3.8 \mathrm{~Hz}), 7.34$ (s, $5 \mathrm{H}, \mathrm{Ar}-\mathrm{H})$.

\section{Aldehyde 88.}

A solution of sodium periodate $(25 \mathrm{~g}, 116.1 \mathrm{mmol})$ in water $(50 \mathrm{ml})$ was added to a solution of $87(18 \mathrm{~g}, 58.1 \mathrm{mmol})$ in $800 \mathrm{ml}$ acetone. The mixture was stirred for a further $30 \mathrm{~min}$ and was then filtered. Evaporation of the acetone followed by extraction into methylene chloride and the usual workup gave $88(15.6 \mathrm{~g}, 97 \%)$. ${ }^{1} \mathrm{H}$ NMR (200 MHz) 1.32, $1.46\left(2 \mathrm{~s}, 6 \mathrm{H}, 2 \mathrm{CH}_{3}\right), 4.33$ (d, $\left.1 \mathrm{H}, \mathrm{H}-3,3.8 \mathrm{~Hz}\right), 4.54\left(\mathrm{dd}, 2 \mathrm{H}, \mathrm{PhCH}_{2}, \mathrm{~J}=12.2 \mathrm{~Hz}\right.$ ), 4.56 (d, $1 \mathrm{H}, \mathrm{H}-2,3.9 \mathrm{~Hz}), 4.63(\mathrm{~m}, 1 \mathrm{H}, \mathrm{H}-4), 6.11(\mathrm{~s}, 1 \mathrm{H}, \mathrm{H}-1, \mathrm{~J}=3.5 \mathrm{~Hz}), 7.21-7.34(\mathrm{~m}, 5 \mathrm{H}$, Ar-H), $9.67(\mathrm{~d}, 1 \mathrm{H}, \mathrm{CHO}, \mathrm{J}=1.6 \mathrm{~Hz})$.

\section{Alcohols 89.}

Phenyl lithium (1.94 ml, $4.0 \mathrm{mmol}$ ) was added to a suspension of copper (I) iodide (369 $\mathrm{mg}, 2.0 \mathrm{mmol})$ in dry THF $(20 \mathrm{ml})$ at $-78^{\circ} \mathrm{C}$. After stirring the solution for $30 \mathrm{~min}$, a solution of 88 (278 $\mathrm{mg}, 1.0 \mathrm{mmol})$ in $10 \mathrm{ml}$ THF was then slowly added and stirring continued for $3 \mathrm{~h}$ at $-7^{\circ} \mathrm{C}$. The reaction was then quenched with saturated ammonium chloride and the solution extracted into methylene chloride. After drying, concentrating and chromatography (20\% ether in hexanes), 89 was obtained as a separable mixture (1:1) of diastereomers (overall yield $271 \mathrm{mg}, 76 \%$ ). Diastereomer 89a (more polar) ${ }^{1} \mathrm{H}$ NMR (200 
MHz) 1.31, $1.46\left(2 \mathrm{~s}, 6 \mathrm{H}, 2 \mathrm{CH}_{3}\right), 3.19$ (d, $\left.1 \mathrm{H}, \mathrm{OH}, \mathrm{J}=7.2 \mathrm{~Hz}\right), 4.00(\mathrm{~d}, 1 \mathrm{H}, \mathrm{H}-3, \mathrm{~J}=3.2$ $\mathrm{Hz}$ ), 4.32 (dd, $1 \mathrm{H}, \mathrm{H}-4, \mathrm{~J}=2.8 \mathrm{~Hz}$ and $5.9 \mathrm{~Hz}$ ), 4.57 (dd, $2 \mathrm{H}, \mathrm{PhCH}_{2}, \mathrm{~J}=11.4 \mathrm{~Hz}$ ), 4.62 (d, $1 \mathrm{H}, \mathrm{H}-2, \mathrm{~J}=6.4 \mathrm{~Hz}$ ), 5.09 (t, $1 \mathrm{H}, \mathrm{H}-5, \mathrm{~J}=6.3 \mathrm{~Hz}$ ), 6.02 (d. $1 \mathrm{H}, \mathrm{H}-1, \mathrm{~J}=3.8 \mathrm{~Hz}$ ), 7.25-7.38 ( $\mathrm{m}, 10 \mathrm{H}, \mathrm{Ar}-\mathrm{H})$. Diastereomer 89b (less polar) ${ }^{1} \mathrm{H}$ NMR $(200 \mathrm{MHz}) 1.31,1.49$ (2 s, $6 \mathrm{H}, 2 \mathrm{CH}_{3}$ ), 2.83 (s, $1 \mathrm{H}, \mathrm{OH}$ ), 3.64 (d, $3.6 \mathrm{~Hz}$ ), 4.34 (m, $1 \mathrm{H}, \mathrm{H}-4$ ), 4.44 (dd, $2 \mathrm{H}$, $\mathrm{PhCH}_{2}, \mathrm{~J}=11.7 \mathrm{~Hz}$ ), 4.60 (d, $1 \mathrm{H}, \mathrm{H}-2, \mathrm{~J}=4.8 \mathrm{~Hz}$ ), 5.06 (d, $\left.1 \mathrm{H}, \mathrm{H}-5, \mathrm{~J}=7.3 \mathrm{~Hz}\right), 6.02$ (d, $1 \mathrm{H}, \mathrm{H}-1, \mathrm{~J}=3.8 \mathrm{~Hz}), 7.25-7.43(\mathrm{~m}, 10 \mathrm{H}, \mathrm{Ar}-\mathrm{H})$.

\section{Dithioacetal 90}

Anhydrous zinc chloride $(2 \mathrm{~g}, 14.0 \mathrm{mmol})$ was added to a solution of benzyl alcohol $89 \mathrm{a}(1 \mathrm{~g}, 2.8 \mathrm{mmol})$ in ethanethiol $(5 \mathrm{ml})$ at $0^{\circ} \mathrm{C}$. The reaction was quenched after $20 \mathrm{~min}$ with $5 \%(\mathrm{v} / \mathrm{v}) \mathrm{HCl}$ and the ethanethiol removed with a stream of nitrogen. The residue was then dissolved in ethyl acetate and the solution washed with brine. After drying, concentrating and chromatography (25\% ethyl acetate in hexanes) $90 \mathrm{a}$ was obtained in $84 \%$ yield (991 mg). ${ }^{1} \mathrm{H} \mathrm{NMR} \mathrm{(200} \mathrm{MHz)} 1.22\left(2 \mathrm{t}, 6 \mathrm{H}, 2 \mathrm{CH}_{3}\right), 2.60$ (m, $\left.4 \mathrm{H}, 2 \mathrm{SCH}_{2}\right), 3.14$ (d, $2 \mathrm{H}, \mathrm{C}-4 \mathrm{OH}$ and C-5 OH, J = 3.2 Hz), $3.76(\mathrm{~m}, 1 \mathrm{H}, \mathrm{H}-2), 3.95-4.03(\mathrm{~m}, 1 \mathrm{H}, \mathrm{H}-4), 4.00$ (d, $1 \mathrm{H}, \mathrm{H}-1, \mathrm{~J}=8.1 \mathrm{~Hz}), 4.18(\mathrm{t}, 1 \mathrm{H}, \mathrm{H}-3, \mathrm{~J}=3.2 \mathrm{~Hz}), 4.80\left(\mathrm{dd}, 2 \mathrm{H}, \mathrm{PhCH}_{2}\right), 4.81(\mathrm{~m}, 1 \mathrm{H}$, $\mathrm{H}-5)$, 7.32-7.42 (m, 10 H, Ar-H).

Similarly, 90b was obtained from alcohol 89b. ${ }^{1} \mathrm{H}$ NMR $1.24\left(2 \mathrm{t}, 6 \mathrm{H}, 2 \mathrm{CH}_{3}\right)$, $2.62\left(\mathrm{q}, 4 \mathrm{H}, 2 \mathrm{SCH}_{2}, \mathrm{~J}=8 \mathrm{~Hz}\right), 2.83(\mathrm{~d}, 1 \mathrm{H}, \mathrm{OH}, \mathrm{J}=7 \mathrm{~Hz}), 3.37(\mathrm{~d}, 1 \mathrm{H}, \mathrm{OH}, \mathrm{J}=4 \mathrm{~Hz})$, 3.85 (br d, 1 H, OH), 3.95 (m, 2 H), 4.05 (m, 2 H), 4.79 (dd, 2 H, $\mathrm{PhCH}_{2}, \mathrm{~J}=12 \mathrm{~Hz}$ ), 4.91 (t, $1 \mathrm{H}, \mathrm{H}-5, \mathrm{~J}=3 \mathrm{~Hz}), 7.26-7.42(\mathrm{~m}, 10 \mathrm{H}, \mathrm{Ar}-\mathrm{H}) . \mathrm{MS}\left(\mathrm{CI}, \mathrm{NH}_{3}, \mathrm{~m} / \mathrm{z}, \%\right) 440\left(\mathrm{M}^{+}+\mathrm{NH}_{4}{ }^{+}\right.$, 1.7), $343\left(\mathrm{M}^{+}-\mathrm{H}_{2} \mathrm{O}-\mathrm{SEt}, 100\right)$.

\section{Orthoformate 93}

To a solution of triol $90 \mathrm{a}(348 \mathrm{mg})$ and trimethyl orthoformate $(0.5 \mathrm{ml})$ in benzene 
(15 ml) at $\mathrm{rt}$ was added pyridine hydrochloride $(50 \mathrm{mg})$. After $3 \mathrm{~h}$, the reaction was poured into brine and the aqueous layer extracted with ether. The organic layer was dried $\left(\mathrm{NaSO}_{4}\right)$ and concentrated. Chromatography (25\% ether in hexanes) first eluted the 1,4 orthoformate (6-membered) (80 mg, 21\%). ${ }^{1} \mathrm{H}$ NMR (200 MHz) 1.24 (m, $\left.6 \mathrm{H}, 2 \mathrm{CH}_{3}\right), 2,79$ (d, $1 \mathrm{H}, \mathrm{OH}$, $\mathrm{J}=6.5 \mathrm{~Hz}), 2.68\left(\mathrm{~m}, 4 \mathrm{H}, 2 \mathrm{SCH}_{2}\right), 3.35\left(\mathrm{~s}, 3 \mathrm{H}, \mathrm{OCH}_{3}\right), 3.68(\mathrm{~m}, 2 \mathrm{H}, \mathrm{H}-1$ and $\mathrm{H}-3), 4.22$ (m, $1 \mathrm{H}, \mathrm{H}-2), 4.69$ (m, $2 \mathrm{H}, \mathrm{H}-4$ and $\mathrm{H}-5), 4.98\left(\mathrm{~s}, 2 \mathrm{H}, \mathrm{CH}_{2} \mathrm{Ph}\right), 5.02(\mathrm{~s}, 1 \mathrm{H}, \mathrm{CH}$ of orthoformate), 7.35-7.52 (m, $10 \mathrm{H}, \mathrm{Ar}-\mathrm{H}) . \mathrm{MS}\left(\mathrm{Cl}, \mathrm{NH}_{3}, \mathrm{~m} / \mathrm{z}, \%\right) 482\left(\mathrm{M}^{+}+\mathrm{NH}_{4}{ }^{+}, 0.8\right), 433$ $\left.\left(\mathrm{MH}^{+}-\mathrm{MeOH}, 12.9\right)\right), 371\left(\mathrm{MH}^{+}-\mathrm{MeOH}-\mathrm{EtSH}\right)$. The 5-membered orthoformate eluted next. ${ }^{1} \mathrm{H}$ NMR (200 MHz) 1.00, $1.08\left(2 \mathrm{t}, 6 \mathrm{H}, 2 \mathrm{CH}_{3}\right), 2.32\left(\mathrm{~m}, 4 \mathrm{H}, 2 \mathrm{SCH}_{2}\right), 2.79(\mathrm{~m}, 2 \mathrm{H}, \mathrm{H}-2$ and $\mathrm{OH}), 3.55\left(\mathrm{~s}, 3 \mathrm{H}, \mathrm{OCH}_{3}\right), 3.80(\mathrm{~d}, 1 \mathrm{H}, \mathrm{H}-1, \mathrm{~J}=9 \mathrm{~Hz}), 3.90(\mathrm{dd}, 1 \mathrm{H}, \mathrm{H}-3, \mathrm{~J}=1 \mathrm{~Hz}$ and $9 \mathrm{~Hz}$ ), 4.83 (dd, $2 \mathrm{H}, \mathrm{PhCH}_{2}, \mathrm{~J}=11 \mathrm{~Hz}$ ), 4.80 (dd, $1 \mathrm{H}, \mathrm{H}-4, \mathrm{~J}=6 \mathrm{~Hz}$ and $9 \mathrm{~Hz}$ ), 5.14 (d, 1 $\mathrm{H}, \mathrm{H}-5, \mathrm{~J}=7 \mathrm{~Hz}$ ), 5.9 (s, $1 \mathrm{H}, \mathrm{CH}$ of orthoformate), 7.35-7.55 (m, $10 \mathrm{H}, \mathrm{Ar}-\mathrm{H}) . \mathrm{MS}$ (CI, $\left.\mathrm{NH}_{3}, \mathrm{~m} / \mathrm{z}, \%\right) 482\left(\mathrm{M}^{+}+\mathrm{NH}_{4}^{+}, 0.05\right), 433\left(\mathrm{MH}^{+}-\mathrm{MeOH}, 0.8\right), 371\left(\mathrm{MH}^{+}-\mathrm{MeOH}-\mathrm{EtSH}\right.$, 100).

\section{Tetrahydrofuran 94}

A solution of orthoformate 93 ( $2.32 \mathrm{~g}$ ) (mixture of 5 and 6-membered) in $25 \mathrm{ml}$ dry formic acid (refluxed over $\mathrm{B}_{2} \mathrm{O}_{3}$ for $6 \mathrm{~h}$ followed by distillation) was stirred for $24 \mathrm{~h}$. The reaction was then quenched with $100 \mathrm{ml}$ water followed by the addition of solid calcium carbonate until the solution was neutral. Extraction into ethyl acetate followed by chromatography yielded the desired tetrahydrofuran (905 mg, 42\%). ${ }^{1} \mathrm{H}$ NMR (200 MHz) 1.21-1.33 (m, $6 \mathrm{H}, 2 \mathrm{CH}_{3}$ ), 2.67-2.85 (m, $4 \mathrm{H}, 2 \mathrm{SCH}_{3}$ ), 3.43 (dd, $1 \mathrm{H}, \mathrm{H}-4, \mathrm{~J}=1.8 \mathrm{~Hz}$ and $5.0 \mathrm{~Hz}$ ), 4.18 (dd, $1 \mathrm{H}, \mathrm{H}-3, \mathrm{~J}=3.8 \mathrm{~Hz}$ ), 4.59 (dd, $2 \mathrm{H}, \mathrm{PhCH}_{2}$ ), 5.00 (s, $1 \mathrm{H}, \mathrm{H}-1, \mathrm{~J}=9.2$ Hz), 5.30 (t, $1 \mathrm{H}, \mathrm{H}-2, \mathrm{~J}=9.2 \mathrm{~Hz}$ ), 5.53 (s, $1 \mathrm{H}, \mathrm{H}-5$ ), 7.35-7.48 (m, 10 H, Ar-H), 7.78 (s, 1 $\mathrm{H}, \mathrm{CHO})$. MS (CI, $\left.\mathrm{NH}_{3}, \mathrm{M} / 2, \%\right) 420\left(\mathrm{M}+\mathrm{NH}_{4}{ }^{+}-\mathrm{CH}_{2} \mathrm{O}, 0.4\right), 371\left(\mathrm{MH}^{+}-\mathrm{EtSH}, 100\right)$. 


\section{ps'-Dinitrobenzophenone 96}

This compound was prepared according to the procedure of Kulin, E.L.; Leffek, K.T. Can J. Chem. 1973, 51, 687.

p,p'-Dinitrobenzophenone tosylhydrazone 97.

A solution of $p, p^{\prime}$-dinitrobenzophenone $96(185 \mathrm{~g}, \quad 0.68 \mathrm{~mol})$ and $p$-toluenesulfonhydrazide (190 g, $1.02 \mathrm{~mol})$ in THF-ethanol $(1: 1,2 \mathrm{~L})$ was refluxed for $18 \mathrm{~h}$. The solvents were then removed at reduced pressure, the residue was filtered, and yellow solids were collected on the filter funnel. After the residue was washed with ethanol several times, the tosylhydrazone 97 was obtained as a pale yellow powder $(262 \mathrm{~g}, 88 \%)$. Recrystallisation of an analytical sample from toluene gave pale yellow crystals: mp $179-180^{\circ} \mathrm{C} ; \mathrm{IR}\left(\mathrm{CH}_{2} \mathrm{Cl}_{2}, \mathrm{~cm}^{-1}\right) \mathrm{1600}, 1525,1340,1160$. ${ }^{1} \mathrm{H} \mathrm{NMR}(200 \mathrm{MHz}) 2.46(\mathrm{~s}, 3 \mathrm{H}$, $\left.\mathrm{CH}_{3}\right), 7.38,7.41,7.56,7.86,8.17$ and 8.43 (d, $\left.12 \mathrm{H}, \mathrm{Ar}-\mathrm{H}\right), 7.70$ (s, 1H, NH); MS (DCI, $\left.\mathrm{NH}_{3}, \mathrm{~m} / \mathrm{e}, \%\right) 441\left(\mathrm{MH}^{+}, 29.3\right), 257\left(\mathrm{MH}^{+}-\mathrm{NNHTs}, 100\right)$.

\section{Bis(p-nitrophenyl)diazomethane 98}

A suspension of the tosylhydrazone $97(3.9 \mathrm{~g}, 6.8 \mathrm{mmol})$ in $1 \mathrm{M}$ sodium hydroxide was vigorously stirred at $75^{\circ} \mathrm{C}$ for $3 \mathrm{~h}$. After cooling to room temperature, the resulting dark orange suspension was extracted with methylene chloride $(3 \times 100 \mathrm{ml})$. The solution was then washed with brine $(3 \times 50 \mathrm{ml})$ and dried over anhydrous sodium sulfate. After removal of solvent at retuced pressure, the desired diazo compound 98 was obtained as a dark orange solid. $1.85 \mathrm{~g}(98 \%)$; mp $137-138^{\circ} \mathrm{C}$ (dec, benzene). IR $\left(\mathrm{CH}_{2} \mathrm{Cl}_{2}, \mathrm{~cm}^{-1}\right) 2040,1525$. ${ }^{1} \mathrm{H}$ NMR (200 MHz) $7.43(\mathrm{~d}, 4 \mathrm{H}, \mathrm{J}=9.3 \mathrm{~Hz}), 8.29(\mathrm{~d}, 4 \mathrm{H}, \mathrm{J}=9.3 \mathrm{~Hz})$.

General Procedure for the preparation of DNB ethers.

To a $0.01 \mathrm{M}$ solution of the alcohol $(99,0.20 \mathrm{~g}, 0.52 \mathrm{mmol})$ and diazo agent $98(0.25$ 
g, $0.88 \mathrm{~mol}$ ) in methylene chloride, at $-20^{\circ} \mathrm{C}$ was added $0.5-2.0 \mathrm{eq}$ of freshly distilled $\mathrm{BF}_{3} \cdot \mathrm{Et}_{2} \mathrm{O}(0.13 \mathrm{ml}, 1.0 \mathrm{mmol})$ dropwise. The reaction mixture was stirred at $-20^{\circ} \mathrm{C}$ for a few hours and saturated sodium bicarbonate solution $(25 \mathrm{ml})$ was added. After warming to room temperature, the mixture was partitioned, and the aqueous phase was extracted with methylene chloride $(2 \times 50 \mathrm{ml})$. The combined organic phases were washed with brine and dried over sodium sulfate. After removal of solvent at reduced pressure, the orange residue was purified by flash chromatography (15\% ether in hexanes) to give the DNB ether $99 \mathrm{a}$ $(0.33 \mathrm{~g}, 98 \%)$.

\section{DNB ether 99a}

White crystals (98\%); mp $118-120^{\circ} \mathrm{C} .{ }^{1} \mathrm{H}$ NMR (200 MHz) 0.5-2.00 (br m, $46 \mathrm{H}$ ), $3.30(\mathrm{~m}, 1 \mathrm{H}, \mathrm{H}-3), 5.69\left(\mathrm{~s}, 1 \mathrm{H}, \mathrm{CH}\left(\mathrm{PhNO}_{2}\right)_{2}\right), 7.51$ (d, 4H, J = 8.6 Hz), 8.19 (d, 4H, J = 8.6 Hz). $\mathrm{MS}\left(\mathrm{CI}, \mathrm{NH}_{3}, \mathrm{~m} / \mathrm{e}, \%\right) 662\left(\mathrm{M}+\mathrm{NH}_{4}^{+}, 1.6\right), 644\left(\mathrm{M}^{+}, 13.7\right)$.

\section{DNB ether 100a}

White crystals (95\%); mp $158-159^{\circ} \mathrm{C} .{ }^{1} \mathrm{H}$ NMR $(200 \mathrm{MHz})$ 0.63-2.06 (br m, 41H), 2.31-2.40 (m, 2H, H-4)3.25 (m, 1H, H-3), 5.31 (br d, 1H, H-6) 5.70 (s, 1H, CH( $\left.\mathrm{PHNO}_{2}\right)_{2}$ ), 7.53 (d, $4 \mathrm{H}, \mathrm{J}=8.8 \mathrm{~Hz}), 8.20$ (d, $4 \mathrm{H}, \mathrm{J}=8.6 \mathrm{~Hz}$ ). MS (CI, NH $, \mathrm{m} / \mathrm{e}, \%) 369$ $\left(\mathrm{M}^{+} \cdot-\mathrm{OCH}\left(\mathrm{PhNO}_{2}\right)_{2}, 100\right)$. HRMS (CI, $\left.\mathrm{NH}_{3}, \mathrm{~m} / \mathrm{e}\right)$ for $\mathrm{C}_{40} \mathrm{H}_{54} \mathrm{~N}_{2} \mathrm{O}_{5}\left(\mathrm{M}^{+}\right)$calcd 642.4033, found 642.4032 .

\section{DNB ether 101a}

Oil (91\%). ${ }^{1} \mathrm{H}$ NMR (200 MHz) 0.82 (t, 3H, H-9), 1.20-1.48 (m, 6H, H-6-H-8), 2.08 (m, 2H, H-5), 2.47 (m, 2H, H-2), 3.52 (t, 2H, H-1), 5.52 (s, 1H, CH( $\left.\mathrm{PhNO}_{2}\right)_{2}$ ), 7.53 (d, 4H, $\mathrm{J}=9.2 \mathrm{~Hz}), 8.14(\mathrm{~d}, 4 \mathrm{H}, \mathrm{J}=9.2 \mathrm{~Hz})$. 


\section{DNB ether 102a}

Yellow foam (90\%). ' 'H NMR (200 MHz) 1.39, $1.49\left(2 \mathrm{~s}, 6 \mathrm{H}, \mathrm{CMe}_{2}\right), 3.78(\mathrm{t}, 2 \mathrm{H}$, H-5), 4.71 (t, 1H, H-4), 4.77 (s, 2H, H-2,3), 5.57 (s, 1H, CH(PhNO $\left.)_{2}\right), 7.45(\mathrm{~m}, 4 \mathrm{H}), 8.24$ (m, 4H). MS (CI, $\left.\mathrm{NH}_{3}, \mathrm{~m} / \mathrm{e}, \%\right)$ 462, $\left(\mathrm{M}+\mathrm{NH}_{4}{ }^{+}, 100\right)$. HRMS (CI, $\left.\mathrm{NH}_{3}, \mathrm{~m} / \mathrm{e}\right)$ for $\mathrm{C}_{21} \mathrm{H}_{21} \mathrm{~N}_{2} \mathrm{O}_{9}$ calcd 445.1247, found 445.1248.

\section{DNB ether 85a}

Oil (89\%). ${ }^{1} \mathrm{H}$ NMR $\left(\mathrm{CDCl}_{3}+\mathrm{D}_{2} \mathrm{O}\right)(200 \mathrm{MHz}) 1.31$ and $1.46\left(2 \mathrm{~s}, 6 \mathrm{H}, \mathrm{CMe}_{2}\right), 3.67$ (dd, $\left.1 \mathrm{H}, \mathrm{H}-6, \mathrm{~J}_{6-6^{\prime}}=10 \mathrm{~Hz}, \mathrm{~J}_{5-6}=5.4 \mathrm{~Hz}\right), 3.78\left(\mathrm{dd}, 1 \mathrm{H}, \mathrm{H}-6^{\prime}, \mathrm{J}_{6-6^{\prime}}=10 \mathrm{~Hz}, \mathrm{~J}_{5-6^{\circ}}=3.2 \mathrm{~Hz}\right.$ ), 4.20-4.28 (m, 1H, H-5), 4.34 (d, 1H, H-3, J = 2.6 Hz), 4.52 (d, 1H, H-2, J = 3.4 Hz), 5.62 (s, $\left.1 \mathrm{H}, \mathrm{CH}\left(\mathrm{PhNO}_{2}\right)_{2}\right), 5.93(\mathrm{~d}, 1 \mathrm{H}, \mathrm{H}-1, \mathrm{~J}=3.4 \mathrm{~Hz}), 7.53(\mathrm{~d}, 4 \mathrm{H}, \mathrm{J}=8.2 \mathrm{~Hz}), 8.21(\mathrm{~d}, 4 \mathrm{H}, \mathrm{J}=$ 8.2 Hz). MS (CI, $\left.\mathrm{NH}_{3}, \mathrm{~m} / \mathrm{e}, \%\right) 494\left(\mathrm{M}+\mathrm{NH}_{4}{ }^{+}, 16.1\right), 476\left(\mathrm{M}^{+}, 3.2\right)$. HRMS (CI, $\mathrm{NH}_{3}$, $\mathrm{m} / \mathrm{e})$ for $\mathrm{C}_{22} \mathrm{H}_{25} \mathrm{~N}_{2} \mathrm{O}_{10}\left(\mathrm{MH}^{+}\right)$calcd 477.1510, found 477.1509.

\section{DNB ether 103}

Oil (94\%). ' 'H NMR (200 MHz) 1.31-1.44 (4s, $\left.12 \mathrm{H}, 2 \mathrm{C}\left(\mathrm{CH}_{3}\right)_{2}\right), 3.63-3.68(\mathrm{~m}, 2 \mathrm{H}$, H-6,6'), 3.75-3.80 (m, 1H, H-5, 4.21 (d, 1H, J = 3.8 Hz), 4.27 (dd, 1H, H-4), 4.65 (d, 1H, $\mathrm{H}-2, \mathrm{~J}=3.9 \mathrm{~Hz}), 5.61\left(\mathrm{~s}, 1 \mathrm{H}, \mathrm{CH}\left(\mathrm{PhNO}_{2}\right)_{2}\right), 5.98(\mathrm{~d}, 1 \mathrm{H}, \mathrm{H}-1, \mathrm{~J}=3.4 \mathrm{~Hz}), 7.51(\mathrm{~d}, 4 \mathrm{H}, \mathrm{J}=$ $8.1 \mathrm{~Hz}), 8.21(\mathrm{~d}, 4 \mathrm{H}, \mathrm{J}=8.1 \mathrm{~Hz}) . \mathrm{MS}\left(\mathrm{CI}, \mathrm{NH}_{3}, \mathrm{~m} / \mathrm{e}, \%\right) 534\left(\mathrm{M}+\mathrm{NH}_{4}{ }^{+}, 14.5\right), 517\left(\mathrm{MH}^{+}\right.$, 43.2), $476\left(\mathrm{M}+\mathrm{NH}_{4}^{+}-58,100\right)$. HRMS (CI, $\left.\mathrm{NH}_{3}, \mathrm{~m} / \mathrm{e}\right)$ for $\mathrm{C}_{25} \mathrm{H}_{28} \mathrm{~N}_{2} \mathrm{O}_{10}\left(\mathrm{MH}^{+}\right)$calcd 517.1822, found 517.1821.

\section{DNB ether 104a}

Oil (82\%). 'H NMR (200 MHz) 1.09 (s, 9H, C( $\left.\left.\mathrm{CH}_{3}\right)_{3}\right), 1.14,1.37$ (2s, 6H, $\left.\mathrm{C}\left(\mathrm{CH}_{3}\right)_{2}\right), 1.95$ (br s, $\left.1 \mathrm{H}, \mathrm{OH}\right), 3.67$ (dd, $1 \mathrm{H}, \mathrm{H}-6, \mathrm{~J}_{6-6^{\circ}}=9.8 \mathrm{~Hz}, \mathrm{~J}_{5-6}=4.4 \mathrm{~Hz}$ ), 3.79 (dd, $\left.1 \mathrm{H}, \mathrm{H}-6^{\prime}, \mathrm{J}_{6-6^{\circ}}=9.8 \mathrm{~Hz}, \mathrm{~J}_{5-6^{\prime}}=1.8 \mathrm{~Hz}\right), 4.09-4.15(\mathrm{~m}, 2 \mathrm{H}, \mathrm{H}-4,5), 4.26(\mathrm{~d}, 1 \mathrm{H}, \mathrm{H}-2, \mathrm{~J}=3.8$ 
$\mathrm{Hz}), 4.50(\mathrm{~d}, 1 \mathrm{H}, \mathrm{H}-3, \mathrm{~J}=1.8 \mathrm{~Hz}), 5.61\left(\mathrm{~s}, 1 \mathrm{H}, \mathrm{CH}\left(\mathrm{PhNO}_{2}\right)_{2}\right), 5.83(\mathrm{~d}, 1 \mathrm{H}, \mathrm{H}-1, \mathrm{~J}=3.8 \mathrm{~Hz})$, 7.40-8.35 (m, $14 \mathrm{H}, \mathrm{Ar}-\mathrm{H})$. HRMS (CI, $\mathrm{NH}_{3}, \mathrm{~m} / \mathrm{e}$ ) for $\mathrm{C}_{38} \mathrm{H}_{43} \mathrm{~N}_{2} \mathrm{O}_{10} \mathrm{Si}\left(\mathrm{MH}^{+}\right)$calcd 715.2689, found 715.2689.

DNB ether 105a

Oil (97\%). ' ${ }^{1} \mathrm{H}$ NMR (200 MHz) 1.15, $1.17\left(2 \mathrm{t}, 6 \mathrm{H}, 2 \mathrm{CH}_{3}\right), 2.63,2.65(2 \mathrm{q}, 4 \mathrm{H}$, $2 \mathrm{SCH}_{2}$ ), 3.62 (d, 2H, H-5,5'), 3.96 (dd, 1H, H-2), 4.15 (m, 2H, H-3,4), 4.21 (d, 1H, H-1), 4.54-4.95 (m, 6H, $\left.\mathrm{CH}_{2} \mathrm{Ph}\right), 5.87$ (s, 1H, CH(PhNO $\left.)_{2}\right)$, 7.22-7.40 (m, 19H, Ar-H), 8.07 (m, 4H). MS (DCI, $\left.\mathrm{NH}_{3}, \mathrm{~m} / \mathrm{e}, \%\right) 721\left(\mathrm{M}^{+}\right.$- SEt, 0.42). HRMS (DCI, $\left.\mathrm{NH}_{3}, \mathrm{~m} / \mathrm{e}\right)$ for $\mathrm{C}_{43} \mathrm{H}_{46} \mathrm{~N}_{2} \mathrm{O}_{8} \mathrm{~S}_{2}\left(\mathrm{M}^{++}\right.$- SEt) calcd 721.2584, found 721.2586.

\section{DNB ether 107a}

White crystals (80\%); mp $155.5-156.5^{\circ} \mathrm{C} .{ }^{1} \mathrm{H}$ NMR (200 MHz) 1.60 (br s, 6H), 1.75 (br s, $6 \mathrm{H}$ ), 2.12 (br s, 3H), 5.88 (s, 1H, CH( $\left.\left(\mathrm{PhNO}_{2}\right)_{2}\right), 7.53$ (d, 4H, J = 8.8 Hz), 8.16 (d, 4H, $\mathrm{J}=8.8 \mathrm{~Hz}) . \mathrm{MS}\left(\mathrm{CI}, \mathrm{NH}_{3}, \mathrm{~m} / \mathrm{e}, \%\right) 426\left(\mathrm{M}+\mathrm{NH}_{4}^{+}, 20.1\right), 408\left(\mathrm{M}^{+}, 6.6\right)$. HRMS (CI, $\left.\mathrm{NH}_{3}, \mathrm{~m} / \mathrm{e}\right)$ for $\mathrm{C}_{23} \mathrm{H}_{28} \mathrm{~N}_{3} \mathrm{O}_{5}\left(\mathrm{M}+\mathrm{NH}_{4}^{+}\right)$calcd 426.2029, found 426.2028.

General Procedure for the Deprotection of DNB Ethers by Pt-Catalytic Hydrogenation.

A suspension of $\mathrm{PtO}_{2}(7 \mathrm{mg}, 15 \% \mathrm{wt})$ in ethanol $(5 \mathrm{ml})$ was stirred under a hydrogen atmosphere until gas uptake was complete. The DNB ether (44 mg, $0.07 \mathrm{mmol}$; 99a) was then added. After ine required amount of hydrogen has been absorbed (about $2 \mathrm{~h}$ ), the reaction was filtered through Celite. The filtrate was stirred with a $\mathrm{pH} 3$ (or $\mathrm{pH} 4$ ) buffer solution, the reaction was monitored by TLC (about $8 \mathrm{~h}$ ). After completion of the hydrolysis, the solvents were evaporated at reduced pressure to dryness, and the residue was taken up in ether $(100 \mathrm{ml})$. The ethereal solution was washed with dilute $\mathrm{HCl}$ solution (e.g., 
5\%) and brine and dried over anhydrous sodium sulfate. Removal of solvent in vacuo and chromatography of the residue afforded the desired alcohol $(99,23 \mathrm{mg}, 89 \%)$.

\section{Alcohol 103a.}

Oil (84\%). ${ }^{1} \mathrm{H}$ NMR $\left(\mathrm{CDCl}_{3}+\mathrm{D}_{2} \mathrm{O}\right)(200 \mathrm{MHz}) 1.30-1.47\left(3 \mathrm{~s}, 12 \mathrm{H}, 2 \mathrm{C}\left(\mathrm{CH}_{3}\right)_{2}\right)$, 3.62-3.70 (m, 2 H, H-6,6'), 3.76-3.83 (m, 1H, H-5), 4.17 (d, 1 H, H-3, J = 3.7 Hz), 4.35 (dd, $1 \mathrm{H}, \mathrm{H}-2, \mathrm{~J}=6.7 \mathrm{~Hz}), 5.98(\mathrm{~d}, 1 \mathrm{H}, \mathrm{H}-1, \mathrm{~J}=3.8 \mathrm{~Hz}) . \mathrm{MS}\left(\mathrm{CI}, \mathrm{NH}_{3}, \mathrm{~m} / \mathrm{c}, \%\right) 261\left(\mathrm{MH}^{+}\right.$, 12.5). HRMS (CI, $\left.\mathrm{NH}_{3}, \mathrm{~m} / \mathrm{e}\right)$ for $\mathrm{C}_{12} \mathrm{H}_{21} \mathrm{O}_{6}\left(\mathrm{MH}^{+}\right)$calcd 261.1338, found 261.1338.

\section{Deprotection of the DNB Ether 101a with $\mathrm{Fe}_{3}(\mathrm{CO})_{12}$.}

To a solution of DNB ether $101 \mathrm{a}(70 \mathrm{mg}, 0.18 \mathrm{mmol})$ in toluene $(5 \mathrm{ml})$, at room temperature, was added benzyltrimethylammonium hydroxide (40\% in methanol, $5 \mathrm{eq}, 369$ $\mathrm{mg})$, followed by $\mathrm{Fe}_{3}(\mathrm{CO})_{12}(2 \mathrm{eq}, 178 \mathrm{mg})$. The resulting dark brown solution was stirred for $2 \mathrm{~h}$. The reaction mixture was diluted with methylene chloride $(50 \mathrm{ml})$ and water (50 $\mathrm{ml})$ and carefully acidified with dilute $\mathrm{HCl}$ solution $(0.5 \mathrm{~N})$ to $\mathrm{pH} 7$. The mixture was partitioned, and the aqueous phase was extracted with methylene chloride $(50 \mathrm{ml})$ once. The combined organic phase was dried over anhydrous sodium sulfate and filtered through a pad of silica gel ( $30 \mathrm{~g}$, silica gel 60 from BDH), washed with $25 \%$ ethyl acetate in hexanes. The filtrate was concentrated in vacuo to an oil. It was then purified by flash chromatography (20\% ethyl acetate in hexanes) to afford the alcohol 101a $(21 \mathrm{mg})$ in $85 \%$ yield.

Deprotection of the DNB Ether 100a by Nickel Boride Catalytic Hydrogenation.

The catalyst was prepared by mixing a solution of sodium borohydride $(75 \mathrm{mg}, 1.97$ mmol) in ethanol $(2 \mathrm{ml})$ to a suspension solution of $\mathrm{Ni}\left(\mathrm{OAc}_{2}, 4 \mathrm{H}_{2} \mathrm{O}(2.18 \mathrm{mmol})\right.$ in EtOH-THF $(1: 1 \mathrm{v} / \mathrm{v}, 15 \mathrm{ml})$ under a hydrogen atmosphere $(1 \mathrm{~atm})$. After evolution of 
hydrogen was complete, a solution of the DNB ether $7 \mathrm{a}(400 \mathrm{mg}, 0.62 \mathrm{mmol})$ in THF (1 ml) was added. After completion of reaction $(8 \mathrm{~h}), 5 \mathrm{ml}$ of $\mathrm{pH} 3$ buffer was added and stirring was continued for $3 \mathrm{~h}$. The mixture was then filtered through Celite and washed with ether. The filtrate was then dissolved in methylene chloride $(50 \mathrm{ml})$. It was washed with $5 \% \mathrm{HCl}$ $(25 \mathrm{ml})$ and brine and dried over anhydrous sodium sulfate. After removal of solvent in vacuo and recrystallisation of the solid residue, the alcohol $100(195 \mathrm{mg})$ was obtained in $81 \%$ yield. 


\section{REFERENCES}

1. Turk, D.C.; in "Haemophilus influenzae", Sell, S.H.; Wright, P.F., Eds., Elsevier Science Publishing Co., Inc. 1982, 1.

2. (a) Branefors-Helander, P.; Erbing, C.; Kenne, L.; Lindberg, B. Carbohydrate Res. 1976, 56,117 .

(b) Branefors-Helander, P.; Erbing, C.; Kenne, L.; Lindberg, B. Acta Chem. Scand. 1976, $B(30), 276$.

(c) (i) Egan, W.; Tsui, F.P.; Climenson, P.A.; Schneerson, R. Carbohydrate Res. 1980, 80,305 .

(ii) Branefors-Helander, P.; Classon, B.; Kenne, L.; Lindberg, B. ibid, 1979, 76, 197.

(d) (i) Branefors-Helander, P.; Kenne, L.; Lindberg, B.; Petterson, K.; Unger, P. ibid, $1981,97,285$.

(ii) Tsui, F.P.; Schneerson, R.; Boykins, R.A.; Karpas, A.B.; Egan, W. ibid, 1981, 97, 293.

(e) (i) Branefors-Helander, P.; Kenne, L.; lindberg, B.; Petersson, K.; Unger, P. ibid, $1981,88,77$.

(ii) Tsui, F.P.; Schneerson, R.; Egan, W. ibid, 1981, 88, 85.

(f) (i) Egan, W.; Tsui, F.P.; Schneerson, R. ibid, 1980, 79, 271.

(ii) Branefors-Helander, P.; Kenne, L.; Lindquist, B. ibid, 1980, 79, 308.

3. Dajani, A.S.; Asmar, B.I., Thimoorthy, M.C. J. Pediatr., 1979, 94, 355.

4. (a) Parke, J.C. Jr.; Schneerson, R.; Robbins, J.B. J. Pediatr., 1972, 81, 765.

(b) Peltola, H.; Kayhty, H.; Sinoven, A.; Makela, H. Pediatrics, 1977, 60, 730.

5. O'Reilly, R.J.; Anderson, P.; Ingram, D.L.; Peter, G.; Smith, D.H. J. Clin. Invest. suppl., $1977,136,63$.

6. Bishop, C.T.; Jennings, H.J. in "The Polysuccharides", 1981, 1, 291.

7. Oeschger, M.P.; Hooke, A.M. in "Haemophilus influenzae", Sell S.H.; Wright, P.F.; 
Elsevier Science Publishing Co., Inc. 1982, 227.

8. Kimura, A.; Gulig, P.A.; McCracken, G.H. Jr.; Loftus, T.A.; Hansen, E.J. Infect. Immunity, 1985, 47, 253.

9. Anderson, P.; Insel, R.; Farsad, P.; Smith, D.H.; Petrusick, T. in "Haemophilus influenzae", Sell, S.H.; Wright, P.F. Elsevier Science Publishing Co., Inc. 1982, 275.

10. (a) Kuo, J.S.C.; Monji, N.; McCoy, D.W. ibid, 243.

(b) Chritine, L.; Williams, M.D.; Barnes, L.; Kuo, J.S.C. ibid. 285.

11. Peltola, H.; Kayhty, H.; Virtanen, M.; Makela, P.H. N. Engl. J. Med. 1984, 310, 1561.

12. Schneerson, R.; Barrera, O.; Sutton, A.; Robbins, J.B. J. Exp. Med., 1980, 152, 361.

13. Tai, J.Y.; Vella, P.P.; McLean, A.A.; Woodhour, A.F.; McAleer, W.J.; Sha, A.;

Dennis-Sykes, C.; Hilleman, M.R. Proc. Soc. Exp. Biol. Med. 1987, 184, 154.

14. Anderson, P. Infect. Immunity 1983, 39, 233.

15. Anderson, P.; Pichichero, M.E.; Insel, R. J. Clin. Invest. 1985, 76, 52.

16. Anderson, P.; Pichichero, M.E.; Insel, R.; Farsad, P.; Santosham, M. J. Infect. Dis. $1985,152,634$.

17. Anderson, P.; Pichichero, M.E.; Insel, R.A. J. Pediatr. 1985, 107, 346.

18. Anderson, P.W.; Pichichero, M.E.; Insel, R.A.; Betts, R.; Eby, R.; Smuth, D.H. J. Immunol. 1986, 137, 1181.

19. Marburg, S.; Jorn, D.; Tolman, R.L.; Arison, B.; McCauley, J.; Kniskern, P.J.;

Hagopian, A.; Vella, P.P. J. Am. Chem. Soc. 1986, 108, 5282.

20. Granoff, D.M.; Weinberg, G.A.; Shackelford, P.G. Pediatr. Res. 1988, 24, 180.

21. Granoff, D.M.; Cates, K.L. J. Pediatr. 1985, 107, 330.

22 Egan, W.; Schneerson, R.; Werner, K.E.; Zon, G. J. Am. Chem. Soc. 1982, 104, 2898.

23. Garegg, P.J.; Lindberg, B.; Samuelsson, B. Carbohydr. Res. 1977, 58, 219.

24. Garegg, P.J.; Samuelsson, B, ibid., 1980, 86, 293.

25. Garegg, P.J.; Johansson, R.; Lindh, I.; Samuelsson, B. ibid. 1986, 150, 285. 
26. Hoogerhout, P.; Evenberg, D.; van Boeckel, C.A.A.; Poolman, J.T.; Beuvery, E.C.; van der Marel, G.A.; van Boom, J.H. Tetrahedron Lett. 1987, 28, 1553.

27. Hermans, J.P.G.; Poot, L.; van der Marel, G.A.; van Boeckel, C.A.A.; Evenberg, D.; Poolman, J.T.; Hoogerhout, P.; van Boom, J.H. Recl. Trav. Chim. Pays-Bas 1987, $106,498$.

28. Hoogerhout, P.; Funke, C.W.; Mellema, J.R.; Wagenaars, G.N.; van Boeckel, C.A.A.; Evenberg, D; Poolman, J.T.; Lefeber, A.W.N.; van der Marel, G.A.; van Boom, J.H. J. Carbohydr. Chem. 1988, 7(2), 399.

29. Wang, Z.Y.; Just, G. Tetrahedron Lett. 1988, 29, 1525.

30. Wang, Z.Y. PhD Thesis, McGill University, 1987.

31. Hakimelahi, G.H.; Proba, Z.A.; Ogilvie, K.K. Can. J. Chem. 1982, 60, 1106.

32. Markiewicz, W.T. J. Chem. Res. Synop., 1979, 24.

33. Chan, L. Unpublished results.

34. Leonard, N.J.; Carraway, K.L. J. Hci. Chem., 1966, 3, 485.

35. Czernecki, S.; Georgoulis, C.; Provelenghiou, C. Tetrahedron Lett. 1976, 39, 3535.

36. Hanessian, S.; Banoub, J. Carbohydrate Res. 1975, 44, C14.

37. Newman, M.S.; Olson, D.R. J. Org. Chem. 1973, 38, 4203.

38. Schmidt, R.R.; Rucker, E. Tetrahedron Lett. 1980, 38, 3224.

39. Corey, E.J.; Suggs, W.J. J. Org. Chem. 1973, 38, 3224.

40. Gigg. R,; Warren, C.D. J. Chem. Soc. C, 1968, 1903.

41. Hutchins, R.O.; Learn, K. J. Org. Chem. 1982, 47, 4382.

42. Gilham, P.T.; Khorana, H.G. J. Am. Chem. Soc. 1958, 80, 6012.

43. Letsinger, R.L.; Mahaderan, V. J. Am. Chem. Soc. 1965, 87, 3826.

44. Letsinger, R.L.; Lunsford, W.B. J. Am. Chem. Soc. 1976, 98, 3655.

45. Beaucage, S.L.; Caruthers, M.H. Tetrahedron Lett. 1981, 22, 1859.

46. Koster, H.; Sinha, N.D.; Biernat, J. Tetrahedron Lett. 1983, $24,5843$. 
47. van Boom, J.H.; Burgers, P.M.J. Tetrahedron Lett. 1976, 22, 4875.

48. Beaucage, S.L.; Caruthers, M.H. Tetrahedron Lett. 1980, 22, 1859.

49. Dembek, P.; Miyoshi, K.; Itakura, K. J.Am. Chem. Soc. 1981, 103, 706.

50. (a) Bock, K.; Pedersen, C. Adv. Carbohydr. Chem. Biochem. 1983, 41, 27.

(b) Bock, K.; Pedersen, C.; Pedersen, H. Adv. Carbohydr. Chem. Biochem. 1984, 42, 193.

51. Rylander P.N. in Catalytic Hydrogenation over Platinum Metals. Academic Press. 1967, 241-243.

52. Cadotte, J.E.; Dutton, G.G.S.; Goldstein, I.J.; Lewis, B.A.; Smith, F.; Van Cleve, J.W. J. Am. Chem. Soc. 1957, 79, 691.

53. Lalonde, M.; Chan, T.H. Synthesis, 1985, 817., Greene, T.W. in "Protective groups in Organic Synthesis" John Wiley \& Sons, Inc. 1981, 44.

54. Johansson, R.; Samuelsson, B. J. Chem. Soc., Chem. Commun. 1984, 201.

55. Takano, S.; Satoh, S. Ogasawara, K. 1988, 59.

56. Kloosterman, M.; Slaghek, T.; Hermans, J.P.G.; van Boom, J.H. Recl.Trav. Chim. Pays-Bas 1984, 103, 335.

57. Kloosterman, M.; Kuyl-Yeheskiely, E.; van Boom, J.H. 1985, 104, 291.

58. Borch, R.f.; Bernstein, M.D.; Durst, H.D. J. Am. Chem. Soc. 1971, 93, 2897.

59. Fraser, B.; Tsui, F.P.; Egan, W. Carbohydrate Res. 1979, 79, 59.

60. Tsui, F.P.; Egan, W.; Summers, M.F.; Byrd, R.A. Carbohydrate Res. 1988, 173, 65.

61. Schneerson, R,; Robbins, J.B. New England J. Med. 1975, 292, 1093.

62. Grzeszczyk, B.; Banaszek, A.; Zamojski, A. Carbohydrate Res. 1988, 175, 215.

63. Chen, S.Y.; Jouille, M.M. J. Org. Chem. 1984, 49, 2168.

64. Klug, A.F.; Untch, K.G.; Fried, J.H. J. Am. Chem. Soc. 1972, 94, 7827.

65. Bock, K.; Thogersen H. Annual Reports on NMR Spectroscopy 1982, 13, 1.

66. Schimdt, R.R. Angew, Chem. Int. Ed. Eng. 1986, 25, 212, and references cited therein. 
67. Leroux, J.; Perlin, A.S. Carbohydrate Res. 1978, 67, 163.

68. Fraser-Reid, B.; Konradson, P.; Mootoo, D.R.; Udodong, U. J. Chem. Soc., Chem.

Commun. 1988, 823.

69. Mootoo, D.R., Date, V., Fraser-Reid, B. J. Am. Chem. Soc. 1988, 110, 2662.

70. Kelly, R.C.; VanRheenen, V. Tetrahedron Lett. 1976, 14, 1067.

71. Sekine, M.; Hata, T. J. Am. Chem. Soc. 1986, 108, 4581.

72. Kulin, E.L.; Leffek, K.T. Can.J. Chem. 1973, 51, 687.

73. Cava, M.P.; Litle, R.L.; Napier, O.R. J.Am. Chem. Soc. 1958, 80, 2257.

74. Tan, C.C. Ph.D. Thesis, McGill University, 1987.

75. (a) Brown, C.A.; Ahuja, V.K. J. Chem. Soc., Chem. Commun. 1973, 553.

(b) Brown, H.C.; Brown, C.A. J. Am. Chem. Soc. 1963, 85, 1005.

76. Des Abbayes, H.; Alper, H. J. Am. Chem. Soc. 1977, 99, 98.

77. Shyluk, W.P., Honeyman, J.; Timell, T.E. Can.J. Chem. 1955, 33, 1202.

78. Jones, J.K.N.; Thompson, J.L. Can. J. Chem. 1957, 35, 955.

79. Gesson, J.P.; Jaquesy, J.C.; Mondon, M. Tetrahedron Lett. 1987, 28,3945

80. Gesson, J.P.; Jaquesy, J.C.; Mondon, M. Tetrahedron Lett. 1987, 28, 3945. 